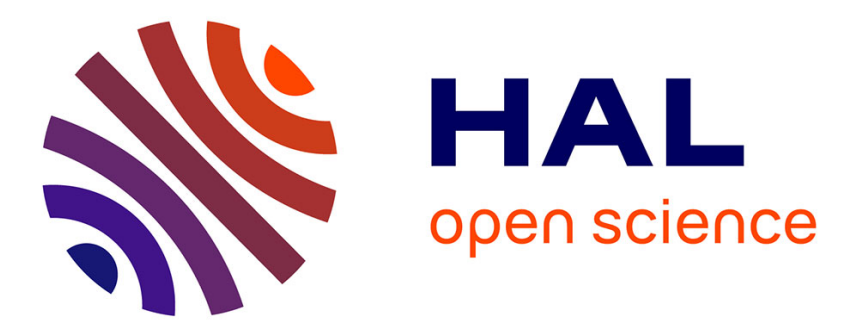

\title{
Transparent exopolymer particles: Effects on carbon cycling in the ocean
}

Xavier Mari, Uta Passow, Christophe Migon, Adrian B. Burd, Louis Legendre

\section{To cite this version:}

Xavier Mari, Uta Passow, Christophe Migon, Adrian B. Burd, Louis Legendre. Transparent exopolymer particles: Effects on carbon cycling in the ocean. Progress in Oceanography, 2017, 151, pp.13 37. 10.1016/j.pocean.2016.11.002 . hal-01408905

\section{HAL Id: hal-01408905 https://hal.sorbonne-universite.fr/hal-01408905}

Submitted on 5 Dec 2016

HAL is a multi-disciplinary open access archive for the deposit and dissemination of scientific research documents, whether they are published or not. The documents may come from teaching and research institutions in France or abroad, or from public or private research centers.
L'archive ouverte pluridisciplinaire HAL, est destinée au dépôt et à la diffusion de documents scientifiques de niveau recherche, publiés ou non, émanant des établissements d'enseignement et de recherche français ou étrangers, des laboratoires publics ou privés. 


\title{
REVIEW
}

\section{Transparent Exopolymer Particles: Effects on carbon cycling in the ocean}

\author{
Mari Xavier, ${ }^{\mathrm{a}, \mathrm{b},}$, Uta Passow $^{\mathrm{c}}$, Christophe Migon ${ }^{\mathrm{b}}$, Adrian B. Burd ${ }^{\mathrm{d}}$, Louis Legendre ${ }^{\mathrm{b}}$
}

a Aix Marseille Université, Université de Toulon, CNRS, IRD, Mediterranean Institute of Oceanography (MIO), 13288, Marseille, France

${ }^{\mathrm{b}}$ Sorbonne Universités, UPMC, Université Paris 06, CNRS, Laboratoire d'Océanographie de Villefranche (LOV), 181 Chemin du Lazaret, 06230 Villefranche-sur-Mer, France

${ }^{\mathrm{c}}$ Marine Science Institute, University of California Santa Barbara, Santa Barbara, CA 93106, USA

${ }^{\mathrm{d}}$ Department of Marine Sciences, University of Georgia, Athens, GA 30602, USA

${ }^{*}$ Corresponding author. Tel.: +33637516518.

E-mail addresses: xavier.mari@ird.fr (X. Mari), uta.passow@lifesci.ucsb.edu (U. Passow), christophe.migon@obs-vlfr.fr (C. Migon), adrianb@uga.edu (A. Burd), legendre@obs-vlfr.fr (L. Legendre). 
Abstract. Transparent Exopolymer Particles (TEP) have received considerable attention since they were first described in the ocean more than 20 years ago. This is because of their carbon-rich composition, their high concentrations in ocean's surface waters, and especially because of their ability to promote aggregation due to their high stickiness (i.e. biological glue). As large aggregates contribute significantly to vertical carbon flux, TEP are commonly seen as a key factor that drives the downward flux of particulate organic carbon (POC). However, the density of TEP is lower than that of seawater, which causes them to remain in surface waters and even move upwards if not ballasted by other particles, which often leads to their accumulation in the sea surface microlayer. Hence we question here the generally accepted view that TEP always increase the downward flux of POC via gravitational settling. In the present reassessment of the role of TEP, we examine how the presence of a pool of non-sinking carbon-rich particulate organic matter in surface waters influences the cycling of organic carbon in the upper ocean at daily to decadal time scales. In particular, we focus on the role of TEP in the retention of organic carbon in surface waters versus downward export, and discuss the potential consequences of climate change on this process and on the efficiency of the biological carbon pump. We show that TEP sink only when ballasted with enough high-density particles to compensate their low density, and hence that their role in vertical POC export is not solely linked to their ability to promote aggregation, but also to their contribution to the buoyancy of POC. It follows that the TEP fraction of POC determines the degree of retention and remineralization of POC in surface waters versus its downward export. A high TEP concentration may temporally decouple primary production and downward export. We identify two main parameters that affect the contribution of TEP to POC cycling; TEP stickiness, and the balance between TEP production and degradation rates. Because stickiness, production and degradation of TEP vary with environmental conditions, the role of TEP in controlling the balance between retention versus export, and hence the drawdown of atmospheric $\mathrm{CO}_{2}$ by the biological carbon pump, can be highly variable, and is likely to be affected by climate change.

Keywords (6 max): Transparent exopolymer particles - Density - Ballast - Aggregation Sinking - Biological carbon pump 


\section{Highlights:}

- Transparent exopolymer particles (TEP) accumulate in surface waters due to their low density.

- TEP sink when ballasted with high-density particles that compensate their low density.

- High relative TEP concentrations decouple primary production and downward POC export.

- The TEP fraction of POC determines POC retention and remineralization in surface waters.

- Climate change may enhance TEP production, which may decrease the biological carbon pump. 


\section{1) Introduction}

\section{1) Transparent exopolymer particles in the ocean: a new approach}

Transparent exopolymer particles (TEP; Alldredge et al. 1993) range in size from $<1$ to $>100 \mu \mathrm{m}$, are ubiquitous in aquatic systems, and are found in high concentrations in a variety of marine environments (Passow 2002a). TEP are very sticky, and it is generally thought that their principal fate is to aggregate with other suspended particles, resulting in the formation of sinking marine snow (Engel et al. 2004a). Indeed, TEP are required to be present in surface waters for phytoplankton blooms to sink (e.g. Logan et al. 1995, Passow et al. 2001). The expression "surface waters" in this text refers to the euphotic zone, i.e. the upper part of the water column where underwater irradiance is high enough to sustain phytoplankton net production. Another class of gel-like particles is the protein-containing particles that can be stained with Coomassie Blue (CSP; Long and Azam 1996). Since CSP were first described, few studies have been conducted on these particles and information about their characteristics and behavior remains very limited. However, contrary to TEP, CSP do not seem to significantly impact aggregation processes (Prieto et al. 2002, Cisternas-Novoa et al. 2015). Therefore, CSP may not play the same pivotal role in carbon cycling as TEP do. Considering the lack of information about CSP and their seemingly low implication in aggregation processes, this class of gel-like particles is not specifically addressed in this paper.

A lesser-known property of TEP may lead to a modification of the generally accepted view that the main effect of TEP on vertical fluxes is always to enhance the downward particle flux. Indeed, Azetsu-Scott and Passow (2004) showed that TEP have a density much lower than that of seawater (i.e. $700-840$ versus $1020-1030 \mathrm{~kg} \mathrm{~m}^{-3}$ ). As a consequence of this property, TEP rise in the water column, and accumulate in the sea surface microlayer (SML, operationally defined as the top $50-100 \mu \mathrm{m}$ of the ocean surface) (e.g. Wurl et al. 2009). This idea was part of the conceptual model of TEP cycling in the ocean of Wurl et al. (2011). Because the density of TEP is lower than that of seawater, the relative proportions of (light) TEP and (denser) solid particles control the buoyancy of organic aggregates (Engel and Schartau 1999, Azetsu-Scott and Passow 2004) and hence determine if particulate organic carbon (POC) is exported downward or retained in surface waters. In the present review, we develop the hypothesis that in situ TEP-rich organic aggregates that linger in surface waters may form frequently. It is only when the relationship between TEP and solid particles changes that they may sink. Such a change in the ratio of TEP to ballasting particles may be due to addition of particles denser than seawater or to preferential degradation of TEP relative to the non-TEP fraction. We explore the consequences for carbon cycling of the existence of such a pool of non-sinking carbon that may temporally decouple production and sinking.

The above hypothesis rests on three lines of evidence, which increasingly focus on TEP. Firstly, there have been reports in the literature for more than two decades of a non-sinking or ascending pool of particulate organic matter in surface waters. Secondly, it is now increasingly recognized that TEP make up a C-rich POC pool in surface waters that does not readily sink. Thirdly, the SML is known to be enriched in TEP. In the remainder of the present introductory section, we examine in turn each of these three lines of evidence.

\section{2) Evidence of a non-sinking or ascending pool of particulate organic matter in surface waters}

In the early 1990s, measurements of the concurrent drawdown of dissolved inorganic carbon (DIC), nitrate and phosphate during both the spring phytoplankton bloom (Sambrotto 
et al. 1993) and summer nutrient-depleted conditions (Michaels et al. 1994) showed that the amount of DIC removed from surface waters largely exceeded that predicted from the removal of nitrate or phosphate using the corresponding Redfield molar ratios of $\mathrm{C}: \mathrm{N}=6.6: 1$ or $\mathrm{C}: \mathrm{P}=106: 1$. Sambrotto et al. (1993) concluded that the amount of carbon removed during the blooms was 40 to $80 \%$ greater than the carbon uptake linked to the production of phytoplankton biomass (with $\mathrm{C}: \mathrm{N}=$ Redfield ratio), and concluded that there must be a large pool of organic matter that cycled through the system with an anomalously high C:N ratio. Interestingly, the discrepancy between the removal of DIC and the downward flux of POC observed over a 5-year period in the Sargasso Sea also supported the idea that the downward POC flux was too low compared to the amount of POC that should have been produced based on the removal of DIC (Michaels et al. 1994). Other studies showed that during nitrate-limited conditions, the phytoplankton C:N uptake ratio was twice the Redfield ratio (Codispoti et al. 1986, Ward et al. 1989, Michaels et al. 1994, Banse 1994, Bates et al. 1996, Marchal et al. 1996, Hansell and Waterhouse 1997, Copin-Montégut 2000).

One hypothesis proposed to explain the non-Redfield production of organic matter, which was called carbon overconsumption (Toggweiler 1993), was the formation of a large standing stock of C-rich organic matter unnoticed until then, cycling through the system with an anomalous $\mathrm{C}: \mathrm{N}$ ratio, i.e. "A second example of preferential recycling calls for the build-up of a carbon-rich detrital pool that does not sink. For this scheme to work, a large standing stock of organic carbon must accumulate in the euphotic zone" (Toggweiler 1993). The proposed pool of non-sinking C-rich organic carbon could have explained not only the observed imbalance between nutrient and DIC uptake during the production of organic matter in the euphotic zone, but also the discrepancy between DIC removal and the POC flux measured with sediment traps at depth. This pool should have been composed of neutrally or positively buoyant substances that remained suspended in the upper water column, or ascended toward the surface.

Another piece of evidence pointing to the existence of such a pool is the occasional retention of marine snow (i.e. composite particles $>500 \mu \mathrm{m}$; Alldredge and Silver 1988) in surface waters. Indeed, the formation of marine snow usually causes the rapid downward transport of particulate organic matter (POM) from surface to the deep ocean (Fowler and Knauer 1986), at velocities ranging between 10 and $1000 \mathrm{~m} \mathrm{~d}^{-1}$ (Alldredge and Silver 1988, Armstrong et al. 2009). On the basis of these measurements, the residence time of marine snow in surface waters should not exceed a few hours (Shanks and Trent 1980). However, studies in various marine systems have reported that large marine snow particles could be retained in surface waters for several days (Stachowitsch et al. 1990, Riebesell 1992, Kiørboe et al. 1998), and even ascend and lead to the formation of organic-rich surface films at the airsea interface, called "slicks", which are visible at the ocean's surface (Ryan et al. 2010, Cunliffe et al. 2013, Wurl et al. 2016). While this retention pathway has been acknowledged for POM, and a corresponding upward POM flux hypothesized (Tsunogai et al. 1980, Obernosterer et al. 2005, Dandonneau et al. 2008), field measurements to estimate upward POM fluxes were only conducted at great depths (e.g. Smith et al. 1989).

\section{3) Transparent exopolymer particles in surface waters: a C-rich POC pool that does not readily sink}

Transparent exopolymer particles are characterized by $\mathrm{C}: \mathrm{N}$ ratios well above Redfield (i.e. mean value >20; Engel and Passow 2001, Mari et al. 2001), and are formed by coagulation (a term used to describe the association between molecules) of colloidal TEP precursors present in the pool of dissolved organic matter (DOM) (Passow 2000). These precursors are produced in large amounts by phytoplankton, especially under nutrient-limited 
conditions (Obernosterer and Herndl 1995). Because of the extracellular release (i.e. exudation) of carbon-rich exopolymers such as polysaccharides from phytoplankton cells, the DOM produced during blooms, especially the high-molecular-weight fraction, has a high C:N molar ratio (Biddanda and Benner 1997, Kepkay et al. 1997). This production of carbonrich DOM may, under some circumstances, lead to the formation of a large pool of DOM that is not stoichiometrically locked into the Redfield $\mathrm{C}: \mathrm{N}$ ratio. The resulting organic matter accumulates in surface waters during nutrient-limited conditions from spring to late summer, both in the dissolved phase as carbohydrate-rich high-molecular-weight DOM (HMW-DOM; Copin-Montégut and Avril 1993, Carlson et al. 1994, Williams 1995, Jones et al. 2013) and in the particulate phase as the extracellular particulate carbohydrates that are TEP (Mari and Burd 1998, Mari et al. 2001). Thus, the surface-water accumulation of organic matter could be the consequence of a high net uptake ratio of inorganic $\mathrm{C}: \mathrm{N}\left(\mathrm{CO}_{2}: \mathrm{NO}_{3} \geq 14\right)$ by phytoplankton, i.e. carbon overconsumption (Fig. 1).

In this context, primary production thus encompasses both the production of phytoplankton biomass and the production of TEP (and their HMW-DOM precursors). However, these products have different elemental ratios. On average, phytoplankton biomass generated through primary production has an elemental ratio close to $\mathrm{C}: \mathrm{N}: \mathrm{P}=106: 16: 1$ (Redfield et al. 1963), but it can differ significantly from that ratio in various areas and at various times. The production of phytoplankton biomass can be represented as follows (Richards 1965):

$$
106 \mathrm{CO}_{2}+122 \mathrm{H}_{2} \mathrm{O}+16 \mathrm{HNO}_{3}+\mathrm{H}_{3} \mathrm{PO}_{4} \rightarrow\left(\mathrm{CH}_{2} \mathrm{O}\right)_{106}\left(\mathrm{NH}_{3}\right)_{16}\left(\mathrm{H}_{3} \mathrm{PO}_{4}\right)+138 \mathrm{O}_{2}
$$

where $\left(\mathrm{CH}_{2} \mathrm{O}\right)_{106}\left(\mathrm{NH}_{3}\right)_{16}\left(\mathrm{H}_{3} \mathrm{PO}_{4}\right)$ is a P-normalized unit of "phosphorylated aminocarbohydrate" biomolecule representing phytoplankton biomass. Production of TEP on the other hand does not follow the Redfield constraints and has a stoichiometry that we simplify as follows:

$$
106 \mathrm{CO}_{2}+105 \mathrm{H}_{2} \mathrm{O} \rightarrow \mathrm{C}_{106} \mathrm{H}_{210} \mathrm{O}_{105}+106 \mathrm{O}_{2}
$$

where $\mathrm{C}_{106} \mathrm{H}_{210} \mathrm{O}_{105}$ is the hypothetical polysaccharide forming TEP precursors. Equations 1 and 2 can be combined in the following equation representing primary production:

$$
\begin{aligned}
& 106(1+n) \mathrm{CO}_{2}+(122+105 n) \mathrm{H}_{2} \mathrm{O}+16 \mathrm{HNO}_{3}+\mathrm{H}_{3} \mathrm{PO}_{4} \rightarrow \\
& \left(\mathrm{CH}_{2} \mathrm{O}\right)_{106}\left(\mathrm{NH}_{3}\right)_{16}\left(\mathrm{H}_{3} \mathrm{PO}_{4}\right)+n \mathrm{C}_{106} \mathrm{H}_{210} \mathrm{O}_{105}+(138+n 106) \mathrm{O}_{2}
\end{aligned}
$$

where $n$ represents the number of polysaccharide molecules exuded for each molecule of phytoplankton biomass produced. The percentage of extracellular release (PER) can be defined as $\mathrm{PER}=[n /(1+n)] \times 100$. For example, for $\mathrm{n}=1$, PER $=50 \%$ of phytoplankton biomass production, i.e. one molecule of polysaccharide would be exuded for each molecule of phytoplankton biomass synthesized. This simple formula combines the production of polysaccharides by phytoplankton (equation 2) with primary production following Redfield stoichiometry (equation 1). Proposed equation 3, although very simple, reconciles the production of phytoplankton biomass with a $\mathrm{C}: \mathrm{N}$ molar ratio of 6.6 , with a $\mathrm{C}: \mathrm{N}$ assimilation ratio $>14$, i.e. the production of extracellular polysaccharides balances the equation in terms of the major elements $\mathrm{C}, \mathrm{N}$ and $\mathrm{P}$.

The percentage of extracellular release from phytoplankton varies from $<5 \%$ to $>50 \%$ of primary production (Thomas 1971, Fogg 1983, Baines and Pace 1991, Fernandez et al. 1994, Biddanda and Benner 1997, Karl et al. 1998, Teira et al. 2001, Marañon et al. 2004, Pugnetti et al. 2005, Alonso-Saez et al. 2008, Lopez-Sandoval et al. 2011) and can even reach $80 \%$ during the decline phase of blooms (Nagata 2000). Considering a mean PER in the range of $10-20 \%$ (Nagata 2000) and assuming that $\sim 50 \%$ of the extracellular release is in the form 
of reactive polysaccharides (i.e. TEP precursors) (Benner et al. 1992, McCarthy et al. 1996, Biddanda and Benner 1997), the production rate of TEP precursors may represent $5-10 \%$ of primary production. Since estimates of global primary production are $50 \mathrm{Pg} \mathrm{C} \mathrm{y}^{-1}$ (Behrenfeld et al. 2005, Carr et al. 2006), global TEP production could represent 2.5-5 $\mathrm{Pg} \mathrm{C} \mathrm{y}^{-1}$. An operational definition of TEP is provided in the Supplementary Material (Section S1).

Several laboratory and mesocosm experiments have established a direct, linear link between TEP concentration, aggregation, and rapid sinking of marine snow (e.g. Passow et al. 1994, Logan et al. 1995, Passow et al. 2001, Gaerdes et al. 2011). In addition, since the discovery of TEP, several studies have stressed the critical role of TEP for aggregation and sinking of particles in various aquatic systems, including oceans (Logan et al. 1995, Dam and Drapeau 1995, Engel 2000, Passow et al. 2001, Fabricius et al. 2003, Wolanski et al. 2003, Engel et al. 2004a, Engel et al. 2004b, Mari et al. 2007), fresh waters (Grossart et al. 1997), and estuaries (Wolanski and Spagnol 2003, Wurl and Holmes 2008, Wetz et al. 2009, Mari et al. 2012). The story is generally simple: owing to their high stickiness, TEP act as biological glue and are thus responsible for the formation of fast-sinking aggregates. However, Passow et al. (2001) observed that only a small fraction of the standing stock of TEP was recovered in traps moored at $500 \mathrm{~m}$, suggesting that TEP may also experience a fate different from aggregation and sinking.

Two major factors that affect the buoyancy of particles are their size and their excess density compared to that of seawater. Below the lower size limit of particulate organic matter (i.e. 0.1 , or 0.22 or $0.7 \mu \mathrm{m}$, according to the type of filter used to separate the dissolved and particulate components), colloids do not sink because of their small size $(<0.1 \mu \mathrm{m}$; Wells and Goldberg 1991). Small organic particles such as individual bacteria do not sink (or sink very slowly) although their density is slightly higher than that of seawater (Inoue et al. 2007). TEP are the only known example of organic particles that are intrinsically positively buoyant, i.e. whose density is less than that of seawater. Some aggregates may also become positively buoyant, e.g. if they contain gas bubbles (Riebesell 1992) or TEP (Engel and Schartau 1999, Chow et al. 2015), but positive buoyancy is not an intrinsic property of their organic matter.

The only published values of TEP density are those of Azetsu-Scott and Passow (2004), and it is thus not possible as yet to combine these values with those from other studies to derive information on the variability of TEP density as a function of environmental conditions, e.g. polymer type, degree of polymer annealing, $\mathrm{pH}$, crystallization of divalent cations, etc. For example, based on the potential mineral crystallization of divalent cations within gels at high $\mathrm{pH}$ (i.e. >8.5-9) and the hypothesized alteration of their density (Chin et al. 1998), one could argue that under high $\mathrm{pH}$ conditions, such mineral crystallization may occur within TEP (they are gels), which may, in turn, increase their density. Given that the usual $\mathrm{pH}$ of surface seawater is $<8.2$, the previous mechanism is not likely to cause increased TEP density under conditions commonly occurring in surface waters, but $\mathrm{pH}$ values $>9$ can occur at sea in very specific circumstances such as inside Phaeocystis colonies during periods of high productivity (Lubbers et al. 1990).

Taking all these factors in consideration, the lower-than-seawater density of TEP makes their fate more complex than that solely inferred from their stickiness, and their relative contribution to the buoyancy of POC may alter the sinking characteristics of marine aggregates (Engel and Schartau 1999, Chow et al. 2015). In the present work, we use the low density of TEP as the piece of the puzzle, which had been overlooked until now, that brings already known pieces into a coherent, novel picture.

1.4) Evidence of the upward flux of TEP: Enrichment of the sea surface microlayer 
Most studies on the SML have reported that this layer was enriched in TEP compared with the underlying water (Azetsu-Scott and Niven 2005, Aller et al. 2005, Kuznetsova et al. 2005, Wurl and Holmes 2008, Wurl et al. 2009, Cunliffe et al. 2009, Wurl et al. 2011, Gao et al. 2012, Karavoltsos et al. 2015, Wurl et al. 2016). During high wind conditions, it was shown that the SML could be depleted in TEP compared to underlying waters (Wurl et al. 2009, Engel and Galgani 2016), and TEP-enrichment was found to be negatively linearly related to wind speed, i.e. TEP depletion occurred at wind speeds higher than about $5 \mathrm{~m} \mathrm{~s}^{-1}$ (Wurl et al. 2009). This relationship between TEP-enrichment and wind speed is consistent with the linear negative relationship observed between the thickness of the SML and wind speed (Liu and Dickhut 1998). Under high wind conditions, the SML breaks and part of the material composing it is mixed into the water column, while another part is aerosolized. According to Gantt et al. (2011), aerosolization of the organic matter forming the SML starts for wind speeds $>3-4 \mathrm{~m} \mathrm{~s}^{-1}$, and is greatest for wind speeds of about $8 \mathrm{~m} \mathrm{~s}^{-1}$. This can explain the high variability in the SML enrichment in TEP reported by Engel and Galgani (2016) as these authors experienced highly variable wind conditions during sampling.

Characterization of the SML largely depends on sampling procedures, which are even more difficult to implement than sampling in the water column. Indeed, the SML is a very fragile system, and samplers collect only the part of the SML adhering to the glass plate or other devices used for sampling, and thus do not recover $100 \%$ of the SML. This means that, at best, the sample collected approaches the real concentration of the materials that compose the SML, but certainly cannot exceed it. In other words, it is easy to underestimate the concentration of TEP (and of other components) in the SML, but virtually impossible to overestimate it.

The thinness of the SML (i.e. $50-100 \mu \mathrm{m}$ ) may seem at odds with the continuous upward flux of TEP hypothesized above. This apparent contradiction is resolved when considering the intense loss processes at play in the SML, such as high photodegradation (Wurl et al. 2011) and enhanced bacterial use (Obernosterer et al. 2005), and the fact that only a small fraction of the TEP pool probably reaches the SML due to the aggregation of TEP with dense particles during their ascent. In addition as discussed above, under conditions of variable winds, the formation of a durable, relatively thick SML may be prevented, or TEP may be lost from the SML through aerosolization (Wilson et al. 2015). In other words, not all positively buoyant TEP reach the SML, and those finding their way to the SML may either be rapidly degraded there or subjected to wind-driven mixing. A large fraction of TEP likely resides in surface waters until aggregating with heavy particles and sinking. Hence TEP could affect global carbon fluxes by influencing the retention time of POC in surface waters, and thus the ratio of in situ remineralization to downward export.

As an analogy, TEP could be compared to gas balloons, which rise in the air when their buoyancy is not counterbalanced by ballast. Continuing this comparison, a large fleet of balloons (i.e. a large TEP pool) would move downwards when $(i)$ there are enough hooks on the balloons to which ballast could be attached (i.e. high stickiness), and (ii) the total weight of the ballast exerts a downward force that exceeds the upward buoyancy force. In the following sections, we examine how the dynamics of the TEP pool control the fate of POC in surface waters and, more generally, carbon cycling. The organization of the discussion reflects the time scales on which various TEP-pertinent processes influence carbon cycling. Those processes that span several time scales are discussed at the time scale of their greatest effect on the carbon cycle.

\section{2) Processes active on daily to monthly time scales}




\section{1) TEP-mediated reduction of downward POC export}

The sinking velocity of marine snow that embeds diatoms is generally very fast (20$200 \mathrm{~m} \mathrm{~d}^{-1}$; Asper 1987, Alldredge and Gotschalk 1988, Armstrong et al. 2009, McDonnell and Buesseler 2010) compared to that of individually sinking diatom cells $\left(0.1-1 \mathrm{~m} \mathrm{~d}^{-1}\right.$; Culver and Smith 1989). This reduces the amount of remineralization experienced by these aggregates in the upper ocean (i.e. $<1000 \mathrm{~m}$ ) and thus increases the proportion of POC that reaches the deep ocean.

The factors that determine the sinking velocity of an aggregate include its size and packaging, the latter including porosity (Iversen and Ploug 2010) and density (Alldredge and Gotschalk 1988, De La Rocha and Passow 2007). The density of an aggregate varies as a function of the density of both TEP (Azetsu-Scott and Passow 2004) and the enclosed solid particles (Asper 1987, Azetsu-Scott and Johnson 1994), and depends on the TEP-to-solid particles ratio (Engel and Schartau 1999, Azetsu-Scott and Passow 2004). Owing to the low TEP density, a high ratio of TEP to solid particles may reduce the sinking velocity of an aggregate, or even lead to an upward flux (Engel and Schartau 1999, Azetsu-Scott and Passow 2004, Mari 2008). Hence TEP may act as a vehicle for transporting upward both light particles and particle-reactive solutes, i.e. dissolved substances that adsorb onto particles. For example, Azetsu-Scott and Niven (2005) have shown that the upward movement of TEP was responsible for the accumulation of ${ }^{234} \mathrm{Th}$ in the SML, which can also be enriched with other trace metals (Ebling and Landing 2015). In other words, increased production of TEP may at times lead to a decrease in the downward particle flux, or even to an upward flux.

The occurrence of slowly sinking particles in the mesopelagic layer (200-1000 m) may indicate the presence of high TEP fractions within sinking POC. At these depths, the density of water is higher than at the surface, which may explain a decrease in the sinking rate of POC, but remineralization of the organic fraction of aggregates may cause an increase in their sinking rate. During their seasonal study over a 1.5-year period south of Canary Islands, Alonso-González et al. (2010) observed that $>60 \%$ of the sinking POM flux at $260 \mathrm{~m}$ (i.e. upper mesopelagic layer) was due to slowly sinking particles $\left(<11 \mathrm{~m} \mathrm{~d}^{-1}\right)$ during the summer/autumn period, whereas during the winter/spring period most of the sinking POM $(53 \%)$ belonged to the highest sinking velocity classes $\left(>326 \mathrm{~m} \mathrm{~d}^{-1}\right)$. Since TEP accumulate in surface waters during summer (Mari and Burd 1998, Mari et al. 2001), the low sinking velocity of aggregates observed by Alonso-González et al. (2010) might have been due to low density caused by a high proportion of TEP. The effect of TEP on the vertical POM flux can be estimated by re-examining literature data that described the annual dynamics of TEP in the Kattegat (Mari and Burd 1998) and the offshore northwestern Mediterranean Sea (DYFAMED site; Mari et al. 2001). A crude estimate of the density of aggregates composed of combined TEP and phytoplankton cells can be obtained from the concentrations of TEP and chlorophyll $a$ in the two studies (calculations are detailed in the Supplementary Material, Section S2). Figures 2 and 3 provide the estimated density of TEP-diatom aggregates in the Kattegat and the Mediterranean Sea, respectively, and the average in situ POC flux, which was modeled in the Kattegat from sediment trap data recorded from 1989 to 1997 (Carstensen et al. 2003), and measured in the Mediterranean Sea with moored sediment traps during 1999 (Miquel et al. 2011). Seasonal variations in the density of TEP-diatom aggregates were similar in the two systems, with a peak of high densities during the early phase of the spring bloom and lower densities during summer. Seasonal variations in average POC flux were also generally similar in the two systems. The similar patterns of seasonal variations in estimated density of aggregates and average in situ POC flux suggest that the downward export of POC from surface waters in the two systems was strongly influenced by aggregate density. 
Although the above exercise shows that the sinking of POC can be influenced by the relative contribution of TEP in aggregates, our results should be taken with caution since the assumptions we used for estimating the density of aggregates were simplifications. Indeed, the solid matter embedded into aggregates consists not only of diatoms but also includes other particles like bacteria, zooplankton debris and minerals. Also, not all TEP or solid particles present in the water are incorporated into aggregates. Nevertheless, the similarity between the seasonal variations in the density of aggregates and the downward POC flux is consistent with the idea that the dynamics of the TEP pool contribute to regulating the downward export characteristics of particles from the surface ocean.

The sinking velocity of POM depends not only on intrinsic properties of the aggregates, but also on seawater dynamic viscosity, hereinafter referred to as viscosity. Although the latter property depends on temperature (Miyake and Koizumi 1948), it has been shown that the 2- to 3-fold increase in seawater viscosity (which is similar to the effect of a $30^{\circ} \mathrm{C}$ decrease in temperature) observed during phytoplankton blooms could be largely attributed to the mucous materials released by cells (Jenkinson 1986, 1993, Jenkinson and Biddanda 1995, Seuront et al. 2006, 2007, Seuront and Vincent 2008, Seuront et al. 2010). While the effect of TEP on seawater viscosity has never been directly investigated, it can be assumed that the mucous material released during blooms consists of TEP and their dissolved precursors. For example, studies conducted over the course of Phaeocystis globosa blooms showed that chlorophyll concentration and seawater viscosity were positively correlated before the disruption of colonies and negatively afterwards, the disruption of colonies being accompanied by the release of TEP (Seuront et al. 2006, 2007). In addition, it was found that the viscosity of seawater collected from the TEP-enriched SML (Wurl and Holmes 2008, Wurl et al. 2009) was much higher than that of subsurface seawater (Zhang et al. 2003), confirming the key effect of TEP concentration on seawater viscosity. Since the viscosity of seawater directly affects several small-scale processes (e.g. viral, bacterial and parasitic infection, predation, nutrient uptake, aggregate formation, and sinking), changes in TEP concentration may indirectly alter not only aggregation, but also the sinking velocities and the remineralization rates of aggregates.

In summary, the accumulation of C-rich pools of HMW-DOM and TEP in surface waters may reduce, at least temporarily, the overall downward export of POM and associated particle-reactive elements. This could lead to a time lag between the production of a large standing stock of POM and its downward export, resulting in increased biological remineralization and photochemical degradation of the POM retained in surface waters.

\section{2) Decoupling of atmospheric deposition of minerals and downward POC export}

The only mechanism that seems able to cause the downward export from surface waters of positively buoyant TEP (apart from sinking of water masses) is the ballasting of TEPcontaining aggregates, i.e. the incorporation of high-density particles that are heavy enough to exceed the buoyancy of the low-density TEP pool. This requires the presence of such dense particles in surface waters, i.e. either during blooms of plankton organisms with heavy mineral tests (i.e. mineral ballast diatoms, coccolithophores, pteropods) or subsequent to atmospheric dust deposition events. Siliceous ballast (also called "opal") is mostly provided by diatoms. Carbonate ballast is mostly provided by coccolithophores and foraminifera, but the tests of the latter do not appear to be as tightly linked to POC flux as coccoliths, as they mostly sink individually (De La Rocha and Passow 2007, Ziveri et al. 2007). As a result, foraminifera are usually not considered when discussing ballasting effects on sinking POC (Fischer and Karakas 2009). Concentrations and masses of other carbonate particles in the water column, such as pteropods shells and calcareous dinophyte shells are very low 
compared to those of coccoliths and foraminifera tests, but they may locally play a role (Schiebel 2002).

While strong correlations are often observed between downward fluxes of POC and the mineral content of sinking particles in the deep ocean, suggesting a potential causal relationship that led to the "ballast effect" concept (Klaas and Archer 2002, Armstrong et al. 2002), this link is not so clear in surface waters (Sanders et al. 2010). A large deposition event of mineral dust may or may not translate into enhanced downward export, depending on the concentration of TEP in surface waters at the time of the event. Such an apparent decoupling between mineral dust deposition and the downward POC flux has been observed at the DYFAMED site (see above), where one study reported a large winter event of Saharan dust deposition that was accompanied by enhanced downward fluxes of minerals and POC (Ternon et al. 2010), whereas another study described such deposition that occurred in summer and was not followed by increased downward fluxes (Heimbürger et al. 2014). The authors of these two studies concluded from their contrasting observations that the main mechanism that controls the downward export flux is atmospheric deposition (Ternon et al. 2010) or primary production (Heimbürger et al. 2014), respectively.

One way to explain how these similar observations can lead to such contradictory results is to consider the role of TEP. Here we estimate the densities of aggregates at the DYFAMED site in winter and summer (our approach is detailed in the Supplementary Material, Section S3). According to our estimates, the TEP-mineral aggregates formed during winter should sink, whereas those formed during summer should rise (Fig. 4). These results indicate that even the strongest dust deposition event recorded between 2003 and 2007 could not counter the large buoyant TEP pool occurring during summer (Fig. 3; Mari et al. 2001), while it could stimulate downward export from surface waters during winter when TEP concentrations were low at DYFAMED.

We conclude from the studies reviewed here that the mineral ballast effect is not in itself a factor that drives the downward flux, but instead it acts in concert with TEP dynamics, i.e. the relative contributions of the positively buoyant TEP and the negatively buoyant ballasting particles determine the upward or downward direction of the vertical flux (Passow 2004).

The lack of downward POC export could cause the retention of mineral particles in surface waters, thus producing a "dam effect", i.e. a surface accumulation of ballasting particles until their total mass reaches the level required to counter the low density of the TEP pool (i.e. to break the dam). Once the critical concentration of mineral particles is reached, a pulsed downward flux of minerals that had accumulated in surface waters may occur. As a result, massive mineral fluxes may occur in the mesopelagic layer seemingly independently from concomitant or recent dust deposition events. Such a decoupling between atmospheric and water-column mineral fluxes was observed at the DYFAMED site during an annual survey when sampling was conducted twice a month (Migon et al. 2002). There, the downward flux (measured at $200 \mathrm{~m}$ ) greatly exceeded at times what would be expected from concomitant or recent atmospheric deposition, consistent with the idea that the additional mineral material "broke the dam" that was retaining the previously accumulated particles in surface waters. This hypothesis is supported by the observation that some metals (i.e. Al, V, $\mathrm{Cr}, \mathrm{Mn}, \mathrm{Fe}, \mathrm{Ni}$ and $\mathrm{Pb}$ ), which have different temporal patterns of atmospheric deposition first accumulate and get homogenized in surface waters before being exported to depth synchronously at a later time (Heimbürger et al. 2014).

\section{3) Observed decoupling between the standing stock of POC in surface waters and the downward POC flux}


The downward POC export at the base of the euphotic zone (i.e. typically within the range of $50-150 \mathrm{~m}$ ) is generally low relative to primary production, with estimates ranging from $<5-10 \%$ derived from ${ }^{234} \mathrm{Th}$ (Buesseler 1998) to $\sim 20 \%$ as modeled for the global ocean (Laws et al. 2000). Observations in a wide range of marine systems have shown that downward POC export from surface waters was often decoupled from primary production. For example, decoupling between the standing stock of suspended and sinking POC was observed in nutrient-enriched upwelling zones (e.g. Pitcher et al. 1991, Kiørboe et al. 1998), in eutrophicated coastal areas (e.g. Rinaldi et al. 1995), during Phaeocystis spp. blooms (Reigstad and Wassmann 2007), and in open-ocean high-nutrient low-chlorophyll (HNLC) systems during iron fertilization experiments (Boyd et al. 2000, Waite and Nodder 2001, Boyd et al. 2007).

During a study conducted in the Benguela upwelling area, Kiørboe et al. (1998) observed that the downward POC fluxes were insignificant despite high formation rates of diatom aggregates (volume concentration between 1000 and $3000 \mu \mathrm{L} \mathrm{L}^{-1}$ ). The dominant diatom group in this upwelling-related bloom was Chaetoceros spp. Laboratory experiments have shown that Chaetoceros spp. produce exceptionally high amounts of TEP precursors, i.e. compounds that can coagulate to form TEP and large aggregates (Kiørboe and Hansen 1993, Crocker and Passow 1995). In their field study, Kiørboe et al. (1998) did not consider the potential role of TEP in retaining diatom aggregates in surface waters given that the low density of TEP was not known then. Instead, these authors attributed the low downward export of aggregates to an inverse ballasting effect of unknown origin. They proposed two potential mechanisms that could have reduced the density of aggregates, i.e. the colonization of aggregates by the positively buoyant heterotrophic dinoflagellate Noctiluca scintillans, and the trapping of gas bubbles in aggregates. But they concluded that the contributions of these two mechanisms to aggregate buoyancy was insignificant. We suggest here that TEP, which were very abundant during the bloom (average volume concentration $\sim 10 \mu \mathrm{L} \mathrm{L}^{-1}$ ), played an important role in increasing the residence time of aggregates in surface waters.

The recurring occurrence of slicks in upwelling areas (Ryan et al. 2010) has been linked to the accumulation of buoyant biogenic surfactants, such as TEP at the air-sea interface (Cunliffe et al. 2013) (surfactants are defined and discussed below, in Section 3.4). The accumulation of such substances at the air-sea interface can be indicative of high TEP production. Hence the frequent occurrence of slicks in upwelling areas is consistent with the hypothesis of a reduced downward flux of POC as a consequence of an upward flux of TEPassociated material.

The repeated mucilage events observed in the eutrophicated coastal Adriatic Sea are associated with intense diatom blooms that mostly involve Chaetoceros spp. and Skeletonema costatum (Herndl and Peduzzi 1988, Stachowitsch et al. 1990, Rinaldi et al. 1995). The occurrence of large non-sinking mucilage aggregates (i.e. particles aggregated by mucilage) in that area has challenged the understanding of export mechanisms for decades (Alldredge and Crocker 1995). How could such large aggregates accumulate at the surface? One hypothesis was that sinking aggregates could become neutrally buoyant when encountering a strong density gradient such as a halocline, where they would accumulate (MacIntyre et al. 1995). Another possibility, which was described for large (i.e. $>2 \mathrm{~cm}$ ) marine snow aggregates, is the formation of gas bubbles by the metabolic activity of attached microbes (Riebesell 1992). In addition, TEP are produced in large quantities in the Adriatic Sea (Schuster and Herndl 1995, Radic et al. 2005), where they could contribute significantly to the formation of buoyant mucilage aggregates. This hypothesis is consistent with the observed dominance of carbohydrates in the composition of the non-sinking mucilage aggregates encountered in the Adriatic Sea (Kovac et al. 2004). Indeed, carbohydrates represent on average $70 \%$ of the 
carbon content of non-sinking mucilage aggregates (Bongiorni et al. 2007), and these aggregates exhibit high C:N molar ratio (i.e. up to 17; Müller-Niklas et al. 1994, Giani et al. 2005), supporting the idea of a high contribution of TEP.

Although Phaeocystis spp. form large blooms, their contribution to the downward export of POC is generally low except when Phaeocystis co-occur with diatoms (Passow and Wassmann 1994, Reigstad and Wassmann 2007). The latter could presumably ballast the aggregates and cause them to sink. Phaeocystis form large colonies, where the small flagellated cells are embedded in a polysaccharide matrix (e.g. Guillard and Hellebust 1971, Eberlein et al. 1985, Lancelot and Mathot 1985, Verity et al. 1988, Hong et al. 1997). When they become senescent, the Phaeocystis colonies disintegrate and the matrix of the colony releases the TEP contained within it (Passow 2000, Passow 2002a, Mari et al. 2005), which can represent up to $60 \%$ of the total POC (Alderkamp et al. 2007). Since Phaeocystis produce very large amounts of TEP, the low downward export at the end of Phaeocystis blooms, when ballasting particles are absent, is likely caused by high TEP concentration. Actually, the production of very high amounts of buoyant TEP during Phaeocystis blooms is responsible for the build-up of carbon-rich mucilaginous material (i.e. TEP) in surface waters (Riebesell et al. 1995) and for foam events that frequently occur after Phaeocystis blooms (e.g. Eberlein et al. 1985, Billen and Fontigny 1987, Blauw et al. 2010). The mucilage that accumulates in surface waters due to Phaeocystis has a long residence time, because of its low biodegradability (Thingstad and Billen 1994). The high C:N ratio of this material (Thingstad and Billen 1994) and the lack of inorganic nutrients in surface waters after the bloom may hamper microbial degradation (Martinussen and Thingstad 1987, Alderkamp et al. 2007) thereby lengthening the retention time of the mucilage near the surface.

Mesoscale iron fertilization experiments in HNLC areas may also provide examples of the high-biomass-low-export scenario. These experiments were conducted at sea to test the "iron hypothesis", which explains the low chlorophyll (LC) observed in some high-nutrient (HN) areas by iron limitation of phytoplankton growth (Martin et al. 1994). It was consequently proposed that iron fertilization could stimulate primary production, which in turn should enhance the rate of downward carbon export. The iron hypothesis was tested during mesoscale iron-fertilization experiments in several oceans, including in the polar Southern Pacific (Boyd et al. 2000, 2007) and Atlantic (Walter et al. 2005), in the equatorial Pacific (Martin et al. 1994, Coale et al. 1996), and in the sub-Arctic Pacific (Tsuda et al. 2003). These experiments clearly showed that enhanced iron supply caused increased primary production in surface waters of HNLC areas, as evidenced by the development of strong phytoplankton blooms, largely diatoms in most cases, and the drawdown of carbon dioxide and nutrients. However, while iron enrichment increased the synthesis of organic carbon by phytoplankton, large export events were generally not observed. Actually, several of the ironinduced massive diatom blooms were retained in surface waters, and the ultimate fate of the algal carbon remained unknown (Boyd et al. 2000, Martin et al. 2013). In some cases, physical dispersion and dilution may have masked export signals (Boyd and Law 2001). Although no increase in the downward flux of POC was observed in most iron fertilization experiments despite enhanced primary production, the downward export of newly formed biogenic material increased significantly inside the fertilized patch during EIFEX (European Iron Fertilization Experiment, South Pacific Ocean), leading to the sinking of at least half of the bloom biomass (Smetacek et al. 2012). The observation of massive sinking during EIFEX may be due to the fact that this experiment lasted 5 weeks compared to 2-3 weeks for previous ones, supporting the idea of a long residence time of blooms in surface waters of fertilized patches before sinking. It could be hypothesized that this long residence time reflected POC buoyancy provided by TEP. Indeed during EIFEX, TEP concentration in the upper $150 \mathrm{~m}$ 
within the fertilized patch increased by a factor $>3$ over the first 30 days before decreasing due to POC sinking (Uta Passow, unpublished results), whereas TEP concentration outside the fertilized patch remained constant. Similarly, during an iron-enrichment experiment in the western sub-Arctic Pacific, the TEP pool increased by a factor $>3$ inside the fertilized patch during the bloom of diatoms, which was dominated by Chaetoceros spp. (Ramaiah et al. 2005). It may thus be hypothesized that, in at least some of the iron fertilization experiments, TEP increased in the fertilized patches thus postponing the downward export of POC beyond the end of the 2 to 3 -week experiments, consistent with our TEP hypothesis.

\section{4) Factors that control the non-sinking POM pool}

The accumulation of TEP in surface waters depends on the rate at which they are produced (gains) and removed (losses). The factors that affect the production rate of TEP or their dissolved precursors include the community composition and physiological state of the phytoplankton, and environmental growth conditions (reviewed in Passow 2002a). The mechanisms of in situ TEP removal include remineralization by bacteria and filter feeders (i.e. some protozoans and appendicularians), and photodegradation. This section discusses the production and in situ removal of the TEP fraction that does not sink and is thus temporarily retained in surface waters.

TEP gain: production by phytoplankton (effects of temperature, nutrients and p $\mathrm{CO}_{2}$ ). The production of TEP is stimulated by elevated temperature through the increased extracellular release of TEP precursors by phytoplankton (Claquin et al. 2008, Piontek et al. 2009, Wohlers et al. 2009, Engel et al. 2011, Fukao et al. 2012, Taucher et al. 2012, Biermann et al. 2014, Seebah et al. 2014). An increase of $2^{\circ} \mathrm{C}$ can enhance extracellular release by up to 54\% (Morán et al. 2006).

Nutrient limitation is accompanied by increased release of extracellular polysaccharides, i.e. TEP precursors, from phytoplankton (Myklestad 1995). This phenomenon, called cellular carbon overflow, is caused by limitation of the synthesis of phytoplankton biomass (Wood and Van Valen 1990), with the coagulation of the resulting excess C-rich DOM creating a pool of C-rich POM (i.e. TEP).

Experimental results have suggested that conditions of high $p \mathrm{CO}_{2}$ (i.e. ocean acidification) also frequently lead to enhanced production of C-rich DOM and TEP (Engel 2002, Engel et al. 2004a, Riebesell et al. 2007, MacGilchrist et al. 2014, Song et al. 2014), but the effect of $p \mathrm{CO}_{2}$ on TEP production is controversial (Egge et al. 2009, Passow et al. 2014). The discrepant results can be explained by interactive effects between different environmental conditions and by differences in the carbon concentrating mechanisms (CCM) of phytoplankton. Indeed, the effect of elevated $p \mathrm{CO}_{2}$ on TEP production varies with the type of CCM used by the various species, i.e. under optimal growth conditions (non-limiting nutrients, saturating light, and near-optimal temperature), elevated $p \mathrm{CO}_{2}$ led to increased TEP production by Skeletonema costatum, but did not change TEP production by Thalassiosira weissflogii (Seebah et al. 2014, Taucher et al. 2015). Furthermore, the response of TEP production to $p \mathrm{CO}_{2}$ was shown to vary within a given species if environmental conditions (light climate, growth temperature, nutrients availability) were sub-optimal or optimal (Passow and Laws 2015). For example, the release of dissolved organic carbon (DOC) and TEP by some species was not affected by elevated $p \mathrm{CO}_{2}$ when nutrients were not limiting, but was enhanced under nitrogen limitation (Giordano et al. 1994, Kim et al. 2011, Taucher et al. 2015). Also, increased $p \mathrm{CO}_{2}$ enhanced TEP production by Thalassiosira weissflogii at suboptimal irradiance and growth temperature, but not under optimal growth conditions (Passow and Laws 2015). The recurrent occurrence of sea-surface slicks in upwelling areas (Ryan et al. 2010), which are characterized by high $\mathrm{pCO}_{2}$ conditions, is consistent with the idea of 
$\mathrm{CO}_{2}$-enhanced TEP production in surface waters followed by an upward flux of TEP toward the SML.

TEP gain: production of TEP precursors by bacteria. Another mechanism of TEP formation could be bacterial activity. Indeed, bacteria frequently produce extracellular polymeric substances (e.g. Decho 1990) that can coagulate to form TEP (Schuster and Herndl 1995, Stoderegger and Herndl 1999, Passow 2002b, Sugimoto et al. 2007, Koch et al. 2014). One possible case of bacterial TEP production could be a response to UV radiation, cited below (TEP loss: photodegradation in surface waters). Another could be the formation of TEP in the dark ocean, which is discussed at the end of the present study (Do non-sinking TEP occur in the dark ocean?)

TEP gain: formation due to surface coagulation and retention by gas bubbles. Gas bubbles are ubiquitous in the open ocean. They can be produced by breaking waves and by biological activity (i.e. respiration, decomposition, and photosynthesis). While there is no global estimate of the contribution of the latter mechanisms to the production of gas bubbles in surface waters, injection of air bubbles caused by breaking waves is well documented. Air bubbles are injected in surface waters when wind speed exceeds $3 \mathrm{~m} \mathrm{~s}^{-1}$. Breaking waves inject significant quantities of air bubbles into the ocean, generating bubble plumes that can disperse in the upper water column to form bubble clouds (Thorpe 1992). These air bubbles range in size from about $20-200 \mu \mathrm{m}$ diameter, and can penetrate down to depths of $15-25 \mathrm{~m}$ (e.g. Crawford and Farmer 1987).

Breaking waves and injection of air bubbles disrupt the SML, and mix downwards TEP that had accumulated at the air-sea interface during calm conditions. Moreover, during their ascent towards the surface, gas bubbles induce coagulation of surface-active colloidal material (including TEP precursors), which in turn stimulates the transformation of DOM into POM. This mechanism has been well described since the pioneering study of Sutcliffe et al. (1963). It is now recognized to promote aggregation (Johnson et al. 1986) and the formation of TEP (Zhou et al. 1998), and was included in the conceptual model of Wurl et al. (2011). Bubbling DOM-rich seawater with air has been used to produce TEP in the laboratory (Mopper et al. 1995, Mari and Kiørboe 1996, Mari 1999). It is estimated that, on the global scale, the winddriven abiotic pathway of TEP formation may transfer $\sim 2 \mathrm{Pg} \mathrm{C} \mathrm{yr}^{-1}$ from DOC to POC (Monahan and Dam 2001).

Rising wind-induced air bubbles not only stimulate TEP formation, but also increase the buoyancy of TEP, lifting them towards the surface. Bubbles that reach the air-sea interface can fuel the SML with the associated TEP and eventually cause the formation of foam, such as observed during Phaeocystis blooms. Alternatively, when bubbles burst, they spray the associated TEP into the atmosphere. The latter mechanism is responsible for the aerosolization of large quantities of polysaccharides (Kuznetsova et al. 2005, Leck and Bigg 2005, Russell et al. 2010, Wilson et al. 2015).

Wind-driven mechanisms can play a significant role in maintaining high TEP concentrations in surface waters by stimulating the abiotic transformation of dissolved precursors into TEP, and trapping micro-bubbles inside TEP (Fig. 5). If TEP are pumped down and up at the rhythm of wind-driven bubble injection, the inclusion of gas bubbles within the TEP matrix could potentially extend their retention time in surface waters by lowering their density. However, surface coagulation on rising bubbles has been shown to stimulate microbial respiration of DOC (Kepkay and Johnson 1989). Therefore, this mechanism not only contributes to maintaining the TEP pool in surface waters, but it also stimulates its remineralization by microbes. Hence the net effect of wind-driven bubble injection on the TEP pool is difficult to estimate and will vary in space and time. 
TEP loss: photodegradation in surface waters. The terms photodegradation, photolysis and photooxidation are often used interchangeably in the marine DOC literature. The definitions of these terms as recommended by the International Union of Pure and Applied Chemistry are provided by Verhoeven (1996). As in Legendre et al. (2015), we use here the general term photodegradation, which refers to the photochemical transformation of a molecule into lower molecular weight fragments, usually in an oxidation process. In surface waters and more particularly the SML, TEP are exposed to strong UV radiation (UVR), which can lead to photodegradation. The penetration depth of UVR in the water column varies greatly, i.e. the depth at which UVR is reduced to $10 \%$ of its surface value ranges for UVB from $\sim 0$ to $5 \mathrm{~m}$ in coastal waters and $\sim 5$ to $15 \mathrm{~m}$ in the open ocean, and for UVA from $\sim 0$ to $8 \mathrm{~m}$ in coastal waters and $\sim 8$ to $45 \mathrm{~m}$ in the open ocean (review in Tedetti and Sempéré 2006), and down to $60 \mathrm{~m}$ in oligotrophic regions (Lee et al. 2013).

The rate of TEP photodegradation has been estimated in UVB-induced photodegradation experiments, using TEP formed from DOM solutions (Ortega-Retuerta et al. 2009b). These experiments were conducted on 50-mL seawater samples containing newly formed TEP, which allowed maximum exposure of TEP to UVB, and the observed average rate of TEP photodegradation by UVB radiation was $\sim 0.3 \mathrm{~d}^{-1}$ (maximum up to $0.7 \mathrm{~d}^{-1}$ ) over the day-night cycle. In other words, in the absence of TEP production and assuming a net photodegradation loss rate of $0.3 \mathrm{~d}^{-1}$, a pool of TEP exposed to the same UVB conditions as used by Ortega-Retuerta et al. (2009b) should totally disappear within $80 \mathrm{~h}$. It follows that a given TEP particle can be exported downwards and thus contribute to the sinking flux of POC only when its retention time in surface waters exposed to UVB does not exceed $80 \mathrm{~h}$. The photodegradation of TEP can be even faster considering that UVA and photosynthetically active radiation also cause TEP transformation, although at a lower rate than UVB (i.e. $<0.17 \mathrm{~d}^{-1}$ ) (Ortega-Retuerta et al. 2009b). The products of TEP photodegradation may be low molecular weight DOM (LMW-DOM) and DIC, the latter because DOC can be photomineralized directly to DIC (Mopper et al. 1991, Miller and Zepp 1995) and a similar process may exist for TEP. Photodegradation of TEP into LMW-DOM that is readily accessible to bacteria likely enhances remineralization (Mopper and Stahovec 1986, Amador et al. 1989, Kieber et al. 1989, Lindell et al. 1995, Wetzel et al. 1995, Benner and Biddanda 1998). Hence the photodegradative pathways of direct photomineralization of TEP to DIC and the photodegradation of TEP into bioavailable LMW-DOM, both should enhance TEP remineralization.

The above experimental results confirmed the results of laboratory experiments conducted by Kovac et al. (1998) on non-sinking mucilage aggregates originating from the northern Adriatic Sea, which have shown that polysaccharides in these aggregates were photolabile. Their photodegradation proceeded through the cleavage of polysaccharide chains to monosaccharides, and the subsequent degradation of the latter. They estimated that about $40 \%$ of the polysaccharides were photodegraded after $30 \mathrm{~h}$, which yields the same photodegradation rate (i.e. $0.3 \mathrm{~d}^{-1}$ ) as that estimated by Ortega-Retuerta et al. (2009b).

The photodegradation loss rate of $0.3 \mathrm{~d}^{-1}$ is likely to be a maximum loss value, for three reasons. Firstly, UVR attenuates rapidly with depth (Fleischmann 1989), and the presence of high TEP and DOC concentrations in non-oligotrophic surface waters may enhance the diffuse attenuation coefficient of light, further reducing exposure (Morris et al. 1995). Hence photodegradation will likely be lower than $0.3 \mathrm{~d}^{-1}$ since on average TEP in surface waters will be exposed to lower UVR. Secondly, the photodegradation experiments were performed with pure TEP, in the absence of solid particles that may protect TEP at sea. Thirdly, wind-driven turbulence may decrease the exposure time of TEP to high UVR by mixing TEP vertically within surface waters. Nevertheless, photodegradation is expected to be a significant 
mechanism of TEP loss, especially for TEP in the SML (Wurl et al. 2011). Kovac et al. (1998) concluded from their above experiments on mucilage aggregates from the northern Adriatic Sea that photochemical degradation in surface waters there was as significant as microbial degradation. Moreover, the LMW-DOM formed as a result of photodegradation is more accessible to microbes than the original TEP, thus fueling heterotrophic activity (Kovac et al. 1998).

It was also suggested that a reaction of bacteria to UVR in the SML could be the production of TEP as sun blocker (Wurl et al. 2011), a mechanism that would contribute to maintain high TEP concentrations in the SML. Hence UVR could not only cause photodegradation of TEP, also stimulate its production by bacteria. The mechanisms involved in the latter could be those described above for the production of TEP precursors by bacteria (TEP gain: production of TEP precursors by bacteria).

TEP loss: in situ remineralization. The colonization of TEP by bacteria (Alldredge et al. 1993, Passow and Alldredge 1994, Schuster and Herndl 1995, Mari and Kiørboe 1996) subjects TEP to intense exoenzymatic activity (Ploug and Passow 2007). For example, there is a strong linear positive relationship between TEP concentration and the $\alpha$ - and $\beta$-glucosidase activity of attached bacteria (Smith et al. 1995). While the rate of bacterial degradation of TEP has not been determined, because of the difficulty in teasing apart formation, degradation and modification of TEP by bacteria, the bacterial degradation of particulate carbohydrates released into the seawater (extracellular) during phytoplankton blooms has been studied.

Although TEP are by definition extracellular particulate carbohydrates (in contrast to cell internal carbohydrates), the particulate carbohydrates found in seawater might not all be TEP. However, we suggest here that the extracellular particulate carbohydrates produced during phytoplankton blooms are mostly TEP (as explained in Supplementary Material; Section S1).

Harvey et al. (1995) showed that the extracellular particulate carbohydrates released by phytoplankton (i.e. TEP) have a biological turnover rate due to bacterial remineralization of $0.53 \mathrm{~d}^{-1}$, which is higher than that of the cellular (i.e. non-TEP) POC (i.e. $0.25 \mathrm{~d}^{-1}$ ). This differential degradation of TEP-C and non-TEP POC is confirmed by Hamanaka et al. (2002), who showed that the production rates of extracellular particulate carbohydrates (i.e. TEP) and non-TEP POC were 0.57 and $0.27 \mathrm{~d}^{-1}$, respectively, and their retention rates in surface waters were 0.53 and $0.21 \mathrm{~d}^{-1}$, respectively (Table 1). Hence $92 \%$ of the TEP-C and $80 \%$ of the nonTEP POC were retained in surface waters as a result of their buoyancy. The remaining $8 \%$ of TEP-C and $20 \%$ of non-TEP POC were exported downwards via gravitational settling. This suggests that the export of TEP-C from surface waters via sinking was small compared to that of non-TEP POC. Because in a steady-state system there is no accumulation of TEP-C and non-TEP POC in surface waters, the rates of retention and degradation should match, and the retention rate of TEP could be used as an estimate of their degradation rate in surface waters.

Considering that photodegradation is rather conservative (i.e. its rate does not change much day after day), an accumulation of TEP in surface waters requires that the rate of production be temporarily higher than the rate of degradation by bacteria. Given that bacterial degradation is frequently controlled by the availability of nitrogen and phosphorous, because the $\mathrm{C}: \mathrm{N}$ and $\mathrm{C}: \mathrm{P}$ ratios of $\mathrm{DOM}$ and $\mathrm{POM}$ are high compared to those of bacterial cells (Amon and Benner 1994), the low nutrient concentrations that often characterize stratified surface waters in summer likely favor the accumulation of TEP during that season. Indeed, although bacteria are able to store carbon under nutrient-limited conditions, cell division is not possible (Zweifel et al. 1993). In addition, the large amounts of dissolved carbohydrates 
released by phytoplankton during severely nutrient-limited conditions, may inhibit bacterial glucosidase activity by endproduct inhibition (Obernosterer and Herndl 1995, Thingstad et al. 1997). These two processes lead to an accumulation of DOM and TEP in surface waters, which is consistent with the results of Zweifel et al. (1993) who showed that the addition of inorganic nutrients to samples from a nutrient-depleted system promoted DOC remineralization, likely including TEP degradation. Nutrient replenishment of surface waters may result from vertical mixing, due to a weakening of the pycnocline, and also takes place via the atmospheric deposition of Saharan dust (e.g. Pulido-Villena et al. 2008, Reche et al. 2009) or anthropogenic aerosols (e.g. Bartoli et al. 2005). Such nutrient inputs likely participate in ending the periods of accumulation of non-sinking, extracellular carbon pool in surface waters by favoring its remineralization.

\section{3) Processes active on monthly to annual time scales}

\section{1) Fate of the accumulated POM pool}

Accumulation of TEP in surface waters may last several weeks or months, and the fate of the accumulated TEP material will differ depending on the relative strengths of aggregation and degradation mechanisms. In addition, water movements may export non-sinking TEP laterally or downwards. This may have a number of ecological and biogeochemical consequences.

Accumulation of TEP. The accumulation of TEP in surface waters has been observed during the summer-stratified period in both temperate areas (see Fig. 2 and 3; Mari and Burd 1998, Mari et al. 2001) and polar waters (Ortega-Retuerta et al. 2009a, Wurl et al. 2011). Hence the time scale of accumulation can reach several months. While the accumulation of TEP in surface waters has only been described for a few systems, the accumulation of C-rich DOM (i.e. TEP precursors) has been reported in a number of systems. One example is the surface accumulation of C-rich DOM in mid-latitudes (Körtzinger et al. 2001). Another example is the observation by Hansell and Waterhouse (1997) along a transect from $67^{\circ} \mathrm{S}$ to $23^{\circ} \mathrm{N}$ in the eastern Pacific Ocean of a positive correlation between the accumulation of $\mathrm{C}$ rich DOM in the upper water column and temperature, and the association of high concentrations of C-rich DOM with the establishment of a robust seasonal thermocline isolating surface from deeper waters. The authors concluded that water column stability or the long residence time imparted by the thermocline was a primary determinant of the accumulation of C-rich DOM in surface waters. This suggests that, high concentrations of TEP may occur for weeks to months in surface waters in stratified systems, either seasonally in mid-latitudes, or more permanently under the tropics.

Aggregation and sinking of TEP. We discussed above the accumulation of TEP in the surface ocean in the absence of ballasting particles. However, the presence of ballasting particles alone does not guarantee the formation of sinking aggregates given that the rate of aggregation is a function of particle numbers, sizes, collision rates and stickiness (Jackson 1990, Jackson and Burd 1998).

The degree to which marine particles stick together is characterized by the stickiness coefficient $(\alpha)$, which is defined as the probability that two particles adhere upon collision. Intraspecific stickiness refers to the interactions between similar particles (e.g. two TEP particles, or two cells of the same phytoplankton species), and interspecific stickiness to the interactions between different types of particle (e.g. one TEP particle and one phytoplankton cell). The interspecific stickiness coefficient is equal to the average of the intraspecific stickiness coefficients (Hansen and Kiørboe 1997). As a result, the dynamics of particles in a bloom are determined by the overall interspecific particle stickiness (Jackson 1990), 
hereinafter called apparent particle stickiness. This characteristic has generally been determined on water samples that included all suspended particles, e.g. TEP and phytoplankton cells (Kiørboe and Hansen 1993, Jackson 1995, Logan et al. 1995, Dam and Drapeau 1995, Engel 2000, Passow et al. 2001, Chow et al. 2015). The range of $\alpha$ in these studies was typically from 0.1 to 0.8 , which is one to two orders of magnitude higher than the stickiness of non-TEP marine organic particles (typically $\alpha \leq 0.01$; Gibbs 1983, Kiørboe et al. 1990, Alldredge and McGillivary 1991, Kiørboe and Hansen 1993). Given that the apparent stickiness of particles in marine water samples is orders of magnitude larger than those of non-TEP particles, the apparent particle stickiness of marine particles seems primarily determined by TEP stickiness.

The surface of phytoplankton cells is often coated with polysaccharides, which stain with Alcian Blue, exuded by the cells, and the stickiness of this cell surface coating appears to be as high as that of TEP (Chow et al. 2015). Chow and co-authors showed that apparent particle stickiness during the development of blooms of Emiliania huxleyi (coccolithophore) varied from $\sim 0.4$ to 1.0 and was closely related to the ratio of extracellular polysaccharides (including both TEP and Alcian Blue cell coating) to the total volume of particles. Hence apparent particle stickiness may be driven by the two types of extracellular polysaccharides. Details on methods to determine apparent particle stickiness can be found in Kiørboe et al. (1990) and Engel (2000), and those that specifically address apparent TEP stickiness (i.e. excluding the stickiness of Alcian Blue stainable cell surface coating) can be found in Mari and Robert (2008).

Aggregation between TEP and solid particles depends on the relative abundances and size of the different pools of particles, and on TEP stickiness. Whereas the exact role of TEP in promoting aggregation remains elusive, e.g. the relative importance of stickiness versus concentration of TEP is debated (Jackson 1995), it is well established that TEP are essential for particle aggregation, and that the high stickiness of TEP is of primary importance in driving aggregation (review in Passow 2002a, Engel et al. 2004b). Changes in stickiness will thus influence aggregate formation and potentially the downward carbon flux. However, some lithogenic minerals also exhibit high stickiness and may thus also drive aggregation (Salter et al. 2010, Passow et al.2014).

It follows that changes in TEP stickiness may influence the fraction of TEP within aggregates and thereby the density of aggregates. Although TEP stickiness is very high, it is also relatively variable as it typically ranges from 0.1 to 0.8 . For example, it has been shown that TEP stickiness decreases at the end of phytoplankton blooms (Kiørboe et al. 1994, Dam and Drapeau 1995), which may be due to variation of the source of TEP and bacterial action on TEP. Another example is the drastic decrease observed in the stickiness of TEP in a sample of surface waters after only one day in darkness (Rochelle-Newall et al. 2010). Hence TEP stickiness seems to vary as a function of the source, degradation stage and possibly age of TEP.

The idea that TEP stickiness varies as a function of age was tested by assuming that the residence time of a water mass could provide an estimate of the age of the local TEP. Mari et al. (2007) and Mari and Robert (2008) used the local e-flushing time (LeFT, measured in days) to quantify the residence time of the water mass in the lagoon of New Caledonia. The LeFT is a synthetic parameter that characterizes the time required for a mass tracer at a given location (control volume) to be reduced by a factor of $1 / \mathrm{e}$ (Jouon et al. 2006) by waters coming from outside the lagoon. The shorter the LeFT, the faster the water mass in the control volume will be replaced. In contrast, longer LeFT indicates slower replacement of the water mass, hence longer residence time. The intraspecific stickiness of TEP collected in surface 
waters of the lagoon along a horizontal LeFT gradient showed a continuous decrease from $\alpha \sim 0.71$ at low LeFT $=0 \mathrm{~d}$ to $\alpha \sim 0.05$ at high LeFT $=47 \mathrm{~d}$, which was consistent with the idea that prolonged exposure to degradation reduces TEP stickiness (Fig. 6). A decrease in TEP stickiness will result in a decrease in aggregation rate, which will in turn reduce the formation rate of aggregates.

Although bacterial activity seems to play a key role in controlling TEP stickiness, ocean acidification and temperature (Seebah et al. 2014) as well as metal concentration (Mari and Robert 2008) have been shown to affect the stickiness of TEP as well. Regarding ocean acidification, molecular dynamic simulations suggest that decreased seawater $\mathrm{pH}$ may affect the structure and stickiness of TEP through the protonation of the carboxylic groups, which may reduce the number of inter- and intrachain hydrogen bonds, and thus prevent the formation of ionic bridges between carboxylic groups and $\mathrm{Ca}^{2+}$ ions ( $\mathrm{Li}$ et al. 2013). However, results from laboratory experiments did not show a clear trend in TEP stickiness and aggregation due to ocean acidification: A decrease in $\mathrm{pH}$ within the range expected for ocean acidification led to a decrease in TEP stickiness when it was caused by a shift in alkalinity (Mari 2008), but not when it was due to an increase in the concentration of DIC (Passow 2012). However, temperature and combined temperature-pH effects were observed, both for the aggregation rate and the sinking velocity of aggregates containing the diatom Thalassiosira weissflogii (Seebah et al. 2014).

In surface waters, low TEP stickiness has been observed to coincide with increased retention rate and low downward flux of POC, and enhanced turbidity (Kiørboe et al. 1998, Mari and Robert 2008, Mari et al. 2012). This would be consistent with the idea that TEP stickiness contributes to determine the balance between retention of particles in surface waters and their downward export. A link between apparent particle stickiness and aggregation and/or sinking of particles has been predicted by model simulations (Boyd et al. 2005, Jackson et al. 2005), but has not been fully supported by experiments or field observations as yet. For example, an increase in apparent particle stickiness of one order of magnitude would decrease the critical concentration for particle aggregation by one order of magnitude, thus increasing the sinking velocities and reducing the concentration of particles in the upper ocean (Boyd et al. 2005). The opposite should be true for decreased apparent particle stickiness. Hence apparent particle stickiness, which depends upon TEP stickiness, should play a central role in both the build-up of a non-sinking POC pool in the upper water column when TEP stickiness is low, and the aggregation and sinking processes when TEP stickiness is high. A conceptual model illustrating the different stickiness states and their potential consequences for carbon cycling is depicted in Fig. 7. On the left-hand side of the Figure, highly sticky TEP rapidly combine with many dense particles to form compact, high-density, fast-sinking aggregates. On the right-hand side of the Figure, TEP with low stickiness coagulate with only a few dense particles, resulting in non-sinking aggregates with a high fraction of TEP compared to solid particles.

What is the fate of the TEP-rich, buoyant, low density aggregates on monthly to annual time scales? As aggregates age, the ratio of TEP to dry mass decreases due to the preferential remineralization and solubilization of the TEP matrix (Ploug and Passow 2007). This decrease in the fraction of TEP in aggregates leads to an increase in the sinking velocity of aggregates as their age increases (Ploug et al. 2008). As a result of their increased sinking velocity, the diffusivity and supply of oxygen within aggregates potentially increases as the aggregate age (Ploug et al. 2008). The sinking velocity of an aggregate will further increase as it reaches nutrient-richer deep waters, where bacterial remineralization of the TEP matrix is intensified. This temporal progression from a buoyant aggregate composed of a large fraction of TEP to a rapidly sinking aggregate that contains less TEP is illustrated in Figure 8. Another 
process that may further accelerate the sinking velocity of sinking aggregates is differential settling, i.e. the encounter rate between large aggregates and small dense particles that sink more slowly than the large ones will increase as the settling velocity of aggregates increases. Enhanced collision rates, which incorporate the small particles into larger aggregates, will increase the proportion of dense particles in large sinking aggregates, further increasing their density and settling velocity.

Theoretical considerations indicate that stickiness not only affects aggregate formation rates, but can also potentially affect the structure of the aggregates themselves. The structure of an aggregate is often represented by the fractal dimension $(D)$ of the particle. This can be thought of as a measure of how the number of constituent particles $(N)$ comprising the aggregate scales with aggregate size (Meakin 1998, Seuront 2010):

$$
N \sim R^{D}
$$

where $R$ is a measure of the aggregate size (e.g. radius of gyration, equivalent spherical diameter, etc.). The fractal dimensions of marine aggregates vary between $\mathrm{D}=1.3-2.3$ (Burd and Jackson 2009), a particle with $D=3$ corresponding to a solid, three-dimensional object. The fractal dimension of an aggregate affects its porosity and hence its density and sinking speed (Jiang and Logan 1991). If particles have a stickiness equal to 1, then two such particles will adhere together the first time they collide; this is termed diffusion limited aggregation (DLA), and the process leads to aggregates with an open, porous structure, and a typical fractal dimension of approximately 2.5 for cluster DLA in three dimensions (Meakin 1998). This is because the high stickiness results in the formation of elongated structures emanating from the core of the aggregate rather like a snowflake. These elongated structures can create spaces within the aggregate that are hard to fill because particles are more likely to collide with the extremities of the elongated structure. Aggregates formed by DLA have a lower fractal dimension, higher porosity, and hence lower excess density and sinking speed.

Alternatively, two particles with much lower values of stickiness will likely undergo multiple collisions with each other before adhering. This potentially allows the smaller of the two particles to work its way into the internal spaces of the larger particles before adhering to it; this is termed reaction limited aggregation and leads to more compact, less porous aggregates with larger fractal dimensions, and lower sinking speeds.

If these theoretical considerations are applicable to the formation of marine snow, then one would expect that aggregates formed in the presence of high TEP abundances would lead to aggregates that are typically more porous with lower settling speeds. Conversely with lower TEP concentrations, one might expect to see more aggregates that are more compact with relatively larger average sinking speeds. To our knowledge, no experiments have been performed to test these ideas, though these structural effects might be hard to separate from the buoyancy effects described above.

The chemical nature of TEP precursors may similarly affect the structure of TEP particles themselves. The arrangement of binding sites along polysaccharide molecules can affect the fractal dimension of TEP aggregates (Metcalfe et al. 2006), though this effect is small. In Metcalfe et al. (2006), the fractal dimension and mean size of particles changed depending on whether polymers were uniformly sticky along their whole lengths, or sticky only at the ends. These results indicate that a single, bulk value for stickiness might be inappropriate when dealing with particles that have different structures and distributions of binding sites.

Coagulation models in marine sciences generally use a single, constant value of stickiness (e.g. Burd and Jackson 2009). Hence changes in stickiness resulting from changes 
in temperature, $\mathrm{pH}$ or bacterial transformation are not incorporated into the models. This is partly because of the lack of good mechanistic understanding of organic particle stickiness in seawater. Interactions between inorganic particles (e.g. clay particles) can be modeled in terms of double layer interactions and van der Waals forces (e.g. Elimelech et al. 1995), whereas for organic particles, steric interactions, hydrophobic interactions and polymer bridging can all play a role, making mechanistic understanding of stickiness much more difficult.

\section{2) Decoupling between primary production and downward export}

Low downward export of POC was often observed during iron fertilization experiments, and it was suggested that this could be explained by a spatio-temporal decoupling between the enhanced primary production and downward export, i.e. export would have occurred far from the fertilization zone and several weeks after the fertilization event (Nodder and Waite 2001). At sea, such decoupling was observed spatially in the California upwelling system, where downward POC export could take place $300 \mathrm{~km}$ away from the primary production area (Plattner et al. 2005). The decoupling between primary production and downward export can also result from a time lag between both, e.g. the 1.5-month delay in the Sargasso Sea between variations in surface chlorophyll $a$ concentrations derived from remotely sensed ocean color and POC sinking measured with sediment traps at $3200 \mathrm{~m}$ depth (Deuser et al. 1990). Similar cases of decoupling between primary production and the downward POC flux were observed in the subtropical North Pacific Ocean (Karl et al. 1996) and the Southern Ocean (Asper and Smith 1999, Buesseler et al. 2003).

Possible long-term effects of an in situ iron-enrichment on the planktonic ecosystem and the biological pump were investigated through model simulations of the 60 days that followed the initial iron input (Southern Ocean Iron RElease Experiment, SOIREE; Hannon et al. 2001). This modeling exercise showed that the 13-day monitoring of the bloom that had been conducted at sea was too short to capture any downward export, i.e. iron-mediated increases in phytoplankton biomass, production, export, and uptake of atmospheric $\mathrm{CO}_{2}$ all peaked about 1-2 weeks after the research vessel had departed the SOIREE area. In addition, the model simulations predicted that most of the net carbon production inside the fertilized patch accumulated in the upper ocean. Indeed, the predicted downward POC export, which started 40-d after the initial iron fertilization, represented only $22 \%$ of the net carbon production. The remaining $78 \%$ of the organic carbon accumulated and was remineralized in surface waters over the 60-day simulation.

Although TEP were not measured during the above studies, it can be hypothesized that the observed spatio-temporal decoupling between primary production and POC export was linked to the build-up of a large pool of non-sinking TEP in surface waters. High production of TEP would have resulted in the formation of non-sinking, or even ascending aggregates (Fig. 9). During their retention period within surface waters, non-sinking aggregates would have been subjected to photodegradation and bacterial remineralization, which would have lowered the TEP fraction in the aging aggregates (Kovac et al. 1998, Ploug and Passow 2007), thereby enhancing their density (Ploug et al. 2008). Once degradation processes had altered the composition of aggregates toward a lower TEP fraction and a density higher than that of seawater, the aggregates could sink out of surface waters.

\section{3) Retention versus export of POC: The role of TEP in the marine carbon cycle}

We estimated the effect of the relative concentrations of TEP and non-TEP particles in aggregates on the partitioning between the retention versus export pathways of POC. To calculate a first-order estimate, we used the simplifying assumptions that $(i)$ extracellular 
particulate carbohydrates consisted mostly of TEP, (ii) only TEP and diatoms are produced (and thus occur) in the euphotic zone, (iii) all TEP and diatoms do aggregate, (iv) TEP and diatoms have specific densities, $(v)$ TEP and diatom have specific carbon contents, ( $v i)$ TEP and non-TEP POC have specific degradation rates (detailed above in Table 1). Calculations are explained in the Supplementary Material, Section S4. We estimated that theoretical aggregates composed of TEP and diatoms would sink only if less than $\sim 5 \%$ of their carbon content consist of TEP, and would be buoyant when TEP would make up more than $5 \%$ of the aggregate's carbon. The formation of aggregates that would sink immediately would thus require a production rate of TEP-C that is less than $\sim 5 \%$ that of diatom carbon.

In the development that follows, the relationship between TEP and the solid particle content of aggregates will be expressed as \% based on carbon content. The value of 5\% TEP-C will be taken as the critical TEP fraction below which aggregates would sink.

In cases where the production rate of TEP would be too high to allow the formation of aggregates that would sink immediately, POC would be retained in surface waters until the proportion of TEP in aggregates had decreased via the differential degradation of TEP-C and non-TEP POC (i.e. 0.53 and $0.21 \mathrm{~d}^{-1}$, respectively). Figure 10a depicts the TEP-C fraction that remains in model aggregates as a function of the age of aggregates, e.g. an aggregate that initially consisted of 20\% TEP-C would contain only 5\% TEP-C after about 3 days. The Figure also shows that model aggregates with an initial TEP-C fraction of $8 \%$ sink after spending about 1 day in the euphotic zone, whereas those with an initial TEP-C fraction of $17 \%$ would sink after 2.7 days. As a result, Figure 10a also depicts the retention time of aggregates (i.e. value for the age of the aggregates on the $\mathrm{X}$-axis) in the euphotic zone before sinking (i.e. when the fraction of TEP-C in aggregates reaches 5\%) according to the initial fraction of TEP-C in aggregates.

We used the above calculations, i.e. the time required for an aggregate to reach 5\% TEP-C and thus, to sink, to estimate the fraction of the initial aggregate that would be remineralized within the euphotic zone versus that exported downwards (Fig. 10b). For example, a model aggregate with an initial 8\% TEP-C will remain suspended in the euphotic zone for about 1 day before sinking, and based on the differential degradation of TEP-C and non-TEP POC, about $25 \%$ of such an aggregate will be remineralized before it starts sinking, and a total of $40 \%$ will be respired before it sinks out of the euphotic zone. As a result, about $20,40,50,60,65$ and $70 \%$ of the POC will be remineralized within the euphotic zone for aggregates initially composed of 5, 8, 11, 14, 17 and 20\% TEP-C, respectively. Calculations assumed that all aggregates formed at $25 \mathrm{~m}$ and sank instantaneously at a constant settling speed of $50 \mathrm{~m} \mathrm{~d}^{-1}$ as soon as the relative TEP-C fraction reached $5 \%$.

The results in Fig. 10a and10b show that the initial TEP concentration in aggregates has a strong influence on the fraction of primary produced carbon that is exported from the euphotic zone before being respired. Export out of the euphotic zone is an important component of the biological carbon pump, which is the biologically mediated process responsible for exporting photosynthetically-produced organic carbon from the euphotic zone to the deep ocean (Volk and Hoffert 1985). Our simple calculations suggest that TEP production relative to primary production influences the fraction of primary production that would be exported, and thus the efficiency of the biological carbon pump (Fig. 10c). A doubling of the TEP-C production from 5 to $10 \%$ of total primary production, and hence an increase of the fraction of TEP-C in aggregates from 5 to $10 \%$, would increase the fraction of POC that is remineralized in the euphotic zone from 23 to $48 \%$, which would decrease the efficiency of the biological carbon pump significantly. 
This simple modeling exercise illustrates that small changes in the production or degradation of TEP-C relative to those of non-TEP POC, as might be expected to occur in the future ocean (see Section 4), would potentially affect the biological pump. For example, a $10 \%$ increase in the relative production rate of TEP-C (i.e. from 0.57 to $0.63 \mathrm{~d}^{-1}$ ), were it not accompanied by a corresponding increase in non-TEP POC production or in TEP-C degradation or sinking, could lead to a doubling of the TEP-C fraction in the surface ocean within $\sim 12 \mathrm{~d}$ (Fig. 11). This in turn could decrease the efficiency of the biological carbon pump as explained in the previous paragraph.

Changes in the production of TEP-C relative to primary production do not modify the remineralization e-folding depth, i.e. the depth by which $63 \%$ of the POC exported from the euphotic zone has become remineralized. Hence, the effect of relative TEP-C production on the biological carbon pump can be investigated by reference to the sole euphotic zone. We derived the remineralization e-folding depth from Figure 10b by calculating the downward flux at depths $>75 \mathrm{~m}$ as a percentage of the flux at $75 \mathrm{~m}$ (Fig. 12), showing that the e-folding depth is independent from the relative TEP-C production (i.e. from the initial TEP-C fraction). The e-folding depth value of $280 \mathrm{~m}$ in our example (Fig. 12) corresponds to an exponent $b=0.75$ in the power law function that is usually used to represent the downward flux of POC, $F$, at a depth $z$ below the base of the euphotic zone $z_{\text {eu }}$ (Martin et al. 1987):

$$
F(z)=F\left(z_{\mathrm{eu}}\right)\left(z / z_{\mathrm{au}}\right)^{-b}
$$

An exponent $b$ of 0.75 is within the range of modeled exponents $b$ (i.e. from 0.5 to 1.4; Kwon et al. 2009) as well as median regional field values (i.e. from 0.4 to 1.8; Guidi et al. 2015; their Table S2).

This modeling exercise indicates that the production of TEP relative to total primary production could influence the efficiency of the biological pump. However, it must be kept in mind that our calculations were based on several simplifying assumptions, stated above.

\section{4) Alteration of the air-sea $\mathrm{CO}_{2}$ exchange}

The SML is particularly enriched in TEP (Wurl and Holmes 2008, Wurl et al. 2016), which may directly act as a surfactant, or form surfactants by association with hydrophobic molecules (Wurl et al, 2009). Surfactants, also called surface-active substances (SAS), are molecules in a liquid that are characterized by surface-active properties linked to the presence of both hydrophilic and hydrophobic structural groups (Hunter and Liss 1981). Owing to their chemical characteristics, SAS tend to accumulate at water phase boundaries, such as the airwater interface, where they lower the surface tension between the two phases.

Because the primary sources of SAS in seawater are phytoplankton exudates (Wilson and Collier 1972, Žutic et al. 1981), SAS concentrations increase during blooms (Gašparović et al. 1998a, Gašparović and Ćosović 2001, Croot et al. 2007). For example, during the iron fertilization experiment EIFEX in the Southern Ocean, SAS concentration markedly increased in the whole upper water column during the course of the experiment and peaked during the senescent phase of the bloom (Croot et al. 2007). Given that this temporal pattern was the same as the pattern of TEP production (review in Passow 2002a), we hypothesize that TEP makes up a significant component of SAS released by phytoplankton. This hypothesis is supported by the fact that the chemical composition of SAS in the SML depends on the dominant phytoplankton species (Gašparović et al. 1998b), and mostly consists of carbohydrates relative to proteins and lipids as indicated by the average ratio carbohydrates:proteins:lipids $=10: 4: 1$ (Williams et al. 1986). In addition, the molecules that accumulate in the SML, i.e. carbohydrates, proteins and lipids (Sieburth et al. 1976, Williams et al. 1986, Gašparović et al. 2007) may form complex thin surfactant films by rearrangement 
and coagulation. For example, TEP may combine with lipids in the SML, and thus contribute to the formation of a SAS film at the air-sea interface. This mechanism could be stimulated by the enhanced coagulation rates that are caused by the high concentrations of dissolved and colloidal precursors in the SML, which are known to enhance TEP production (Wurl et al. 2011). The presence of SAS at the air-sea interface influences energy and mass transfers at the ocean-atmosphere boundary layer, and thus plays an important role in biogeochemical cycles (Croot et al. 2007). High SAS concentration especially decreases the rate of air-sea gas exchange (Frew et al. 1990, Frew et al. 2002, Tsai and Liu 2003, Frew 2005, Wurl et al. 2016). Using satellite-based estimates of chlorophyll concentration as an indicator of the presence of SAS (as proposed by Asher 1997), Tsai and Liu (2003) modeled the global effects of SAS (i.e. produced during primary production) on the atmosphere-ocean $\mathrm{CO}_{2}$ fluxes across the air-sea interface. They found that the average percent reduction of the $\mathrm{CO}_{2}$ flux into the ocean caused by SAS was about twice that of outgassing, which resulted in an overall decrease in the net global uptake of $\mathrm{CO}_{2}$ by the oceans. For example, they estimated that under a global SAS coverage corresponding to a global primary productivity $>15 \mathrm{~g} \mathrm{C} \mathrm{m}^{-2}$ month $^{-1}$ (i.e. a value similar to the mean primary production of the Atlantic Ocean; Longhurst et al. 1995), the annual net $\mathrm{CO}_{2}$ flux would be reduced by half compared with a scenario without SAS at the air-sea interface. In a different study, Wurl et al. (2016) estimated that, compared with a non-SAS scenario, the presence of SAS could reduce the flux of $\mathrm{CO}_{2}$ at the air-sea interface by 5 and $15 \%$ in the open and coastal waters, respectively, of the Mediterranean Sea.

The actual fraction of TEP in SAS remains to be determined. Nevertheless, the above studies lead us to hypothesize that the accumulation of TEP in surface waters and the formation of a TEP-enriched SML may significantly lower the uptake of $\mathrm{CO}_{2}$ by the ocean than if there were no SAS.

Another effect of TEP on gas exchange at the air-sea interface may be related to the role of organic carbon in reducing air-sea gas exchange, i.e. $\mathrm{CO}_{2}$ exchange depend on the concentration of total organic carbon in the top $2 \mathrm{~cm}$ of the water column (Calleja et al. 2009). Hence air-sea gas exchanges may not to be solely modulated by the presence of a SASenriched SML, but more generally by the concentration of organic carbon in surface waters, including TEP.

\section{4) Processes active on annual to decadal time scales}

Anthropogenic carbon emissions have a significant effect on the oceans (e.g. Bijma et al. 2013), especially on phytoplankton production (Reusch and Boyd 2013). The anthropogenic release of $\mathrm{CO}_{2}$ leads to warming of both the atmosphere and the surface ocean (e.g. Rayner et al. 2003, Belkin 2009, Reid and Beaugrand 2012), and to ocean acidification (e.g. Caldeira and Wickett 2003, Caldeira 2007, Cao and Caldeira 2008, Doney et al. 2009).

This section examines some possible first order responses of TEP dynamics to global warming and ocean acidification (Table 2), but the complex effects resulting from interactions and synergies cannot be currently predicted. Based on the primary responses in Table 2, we hypothesize here that the overall global-change enhancement of TEP production might lead to the increased temporary retention of POC in surface waters and a concomitant decrease in the efficiency of the biological carbon pump instead of the increase in the downward POC flux that had been postulated in some previous studies (e.g. Arrigo 2007, Riebesell et al. 2007). The effects on TEP of the different processes listed in Table 2 were discussed in previous sections. 
The predicted increase in the global mean atmospheric temperature expected by the end of the 21 st century $\left(>1.5^{\circ} \mathrm{C}\right.$ relative to the period 1850-1900; Collins et al. 2013) and resulting increase in average surface ocean temperature (from 1 to $3^{\circ} \mathrm{C}$; Collins et al. 2013) lead us to hypothesize that the concentration of TEP in surface waters will increase in the future ocean. Indeed, there is an overall increase in TEP production with increasing seawater temperature (Ramaiah et al. 2001, Claquin et al. 2008, Piontek et al. 2009, Wohlers et al. 2009, Engel et al. 2011, Fukao et al. 2012, Taucher et al. 2012, Seebah et al. 2014, Taucher et al. 2015). The correlation between temperature anomalies in the Mediterranean Sea and the occurrence of mucilage events over the past 200 years (Danovaro et al. 2009) also supports the hypothesized link between increased temperature and increased concentration of TEP in surface waters.

In contrast to earlier predictions (Arrigo 2007, Riebesell et al. 2007) we propose here that an increase in TEP production will result in $(i)$ the accumulation of TEP in surface waters, especially in the SML, and consequently (ii) a reduction in the ratio of organic carbon export to primary production. The latter is consistent with the negative correlation between the temperature of surface waters and the export:production ratio predicted for the open ocean by a model that was validated against field data from various marine systems (Laws et al. 2000). Our viewpoint is also consistent with the observed $31 \%$ decrease in the biological drawdown of DIC in surface waters with an increase in seawater temperature of $2-6^{\circ} \mathrm{C}$ during a mesocosm experiment (Wohlers et al. 2009), which could be explained by the observed increase in TEP concentration under elevated temperature (Wohlers et al. 2009), but also by a decrease in particle stickiness as suggested by Simon et al. (2014).

Parallel to the increase in sea-surface temperature, vertical stratification is also expected to increase (Behrenfeld et al. 2006, Collins et al. 2013) with a concomitant decrease in the depth of the mixed layer (Boyd et al. 2007, Rost et al. 2008, Bijma et al. 2013, Reusch and Boyd 2013). Decrease in the depth of the mixed layer and increased vertical stratification will reduce nutrient availability in surface waters (Rost et al. 2008, Steinacher et al. 2010), leading to longer periods of nutrient limitation. As discussed above (Section 2.4), nutrient limitation may cause enhanced TEP production relative to phytoplankton biomass production and a possible concomitant reduction of bacterial degradation. Hence the increase in water-column stratification may both stimulate TEP production and favor the retention of TEP in surface waters.

The increase in partial pressure of $\mathrm{CO}_{2}\left(p \mathrm{CO}_{2}\right)$ in seawater and the resulting ocean acidification frequently lead to carbon overconsumption in phytoplankton, with production of carbohydrates and TEP (Engel 2002, Engel et al. 2004a, Riebesell et al. 2007, Thornton 2009, Endres et al. 2014, Engel et al. 2014, Taucher et al. 2015). A study of the combined effect of increasing temperature and lower $\mathrm{pH}$ on TEP production by the diatom Thalassiosira weissflogii (Seebah et al. 2014) confirmed that higher $\mathrm{pCO}_{2}$ combined with elevated temperature resulted in increased TEP production, which was accompanied by decreased aggregation and sinking velocity of aggregates. In addition, laboratory experiments (Mari 2008) suggested that lower ocean $\mathrm{pH}$ (due to an alkalinity perturbation, as might be expected in nearshore areas impacted by anthropogenic pollutants) may decrease the stickiness of TEP, which in turn may lower the density of marine aggregates. However, a change in $\mathrm{pH}$ due to DIC perturbations, as expected in the future ocean, did not change TEP stickiness (Passow 2012).

The above mentioned mechanisms may lead to the establishment of a "mucous plug" in surface waters, which could potentially alter the delivery of biogenic carbon to deeper waters by enhancing the retention time in surface waters and lowering the sinking velocity of particles. Hence the mucous plug mechanism may create a positive feedback loop of increasing atmospheric $\mathrm{CO}_{2}$. 
While the above mechanisms may synergistically contribute to TEP-enrichment of surface waters in a global change perspective, other processes may, on the contrary, reduce the production of TEP and/or enhance its rate of removal, which may in turn weaken the hypothesized establishment of a "mucous plug". For example, a shallower mixed layer will expose TEP in that layer to longer periods of high UV radiation and hence photodegradation. In addition, it was shown that the bacterial turnover of polysaccharides via exoenzymes was faster at the lower $\mathrm{pH}$ expected for the surface ocean within the next 100 years, via an optimization of glucosidase activity, which could lead to increased rate of TEP loss in the future ocean (Piontek et al. 2010).

Other factors that are and will likely be affected by climate change may alter the production and loss rate of TEP, although there are large uncertainties about even the sign of the climate-change effects. For example, it was shown that dust inputs from the atmosphere are likely to change, but it is unclear whether the dust load to the ocean will increase or decrease (e.g. Mahowald and Luo 2003, Heimbürger et al. 2010, Mahowald et al. 2010). Determining the sign of changes in dust deposition is crucial for assessing the fate of POC in surface waters since dust influences the ballasting of TEP-containing aggregates and frequently promotes aggregation (see Section 2.2; Passow et al. 2014). Another example of a factor that could potentially affect TEP production and removal is the deposition of atmospheric black carbon (BC). Indeed, the input of BC to the ocean could stimulate opposite pathways of TEP cycling in the surface ocean, i.e. enhanced formation of TEP from DOM (Mari et al. 2014), or stimulation of bacterial activity (Mari et al. 2014, Malits et al. 2015), which may in turn enhance TEP degradation. Since the frequency, length and intensity of wildfires is likely to increase due to global change (Jolly et al. 2014), and since anthropogenic emissions of BC are currently increasing (Bao et al. 2015), the load of BC to the surface ocean may increase, which may either stimulate the production or removal of TEP. Changes in phytoplankton species composition due to changing environmental conditions and subsequent changes in food web structure (review in Bijma et al. 2013) will also affect TEP production and loss rates.

\section{5) Conclusions}

The formation of organic carbon in surface waters and its subsequent export to depth is a crucial part of the oceanic carbon cycle. Our study addressed the role of TEP on carbon cycling by focusing on surface waters processes, but it could also be hypothesized that processes in the dark ocean are affected by the occurrence of such particles (this hypothesis is briefly described in the Supplementary Material, Section S5). The processes that lead to the aggregation of particles and that determine the rates at which they sink are extremely important. Even though we know that transparent exopolymer particles play a crucial role in particle aggregation, we lack a firm mechanistic understanding of how TEP drive this process and, more importantly, in how they determine particle retention time and sinking speed. We do know that TEP accumulate in surface waters and are produced by phytoplankton and bacteria, but the possibility that high TEP concentrations could decouple primary production and POC export may help in explaining the observed timing of export events. More importantly, we need a better understanding of how environmental changes affect TEP production and properties in order to predict how the role of TEP in the ocean carbon cycle might change under future climate scenarios. 
Acknowledgements. This work follows from discussions among co-authors during the Workshop on the Effects of climate change on the biologically-driven carbon pump, held during the Third International Symposium on the Effects of Climate Change on the World's Oceans (Santos City, Brazil, March 23-27, 2015) organized by the North Pacific Marine Science Organization (PICES). This research was supported by funding from Université Pierre et Marie Curie Paris 06 (UPMC) and CNRS to the Villefranche Oceanography Laboratory (LL, CM, XM), and from the National Science Foundation OCE-1041038 and OCE-1538602 to UP, and OCE-0645485 to AB. We thank two anonymous reviewers for their thoughtful comments and suggestions. 


\section{References}

Alderkamp, A.-C., Buma, A.G.J., van Rijssel, M., 2007. The carbohydrates of Phaeocystis and their degradation in the microbial food web. Biogeochemistry 83(1-3), 99-118, doi:10.1007/s10533-007-9078-2.

Alldredge, A.L., Crocker, K.M., 1995. Why do sinking mucilage aggregates accumulate in the water column? Science of the Total Environment 165(1-3), 15-22, doi:10.1016/0048-9697(95)04539-D.

Alldredge, A.L., Gotschalk, C., 1988. In situ settling behavior of marine snow. Limnology and Oceanography 33(3), 339-351, doi:10.4319/lo.1988.33.3.0339.

Alldredge, A.L., McGillivary, P., 1991. The attachment probabilities of marine snow and their implications for particle coagulation in the ocean. Deep-Sea Research A 38(4), 431-443, doi:10.1016/0198-0149(91)90045-H.

Alldredge, A.L., Passow, U., Logan, B.E., 1993. The abundance and significance of a class of large, transparent organic particles in the ocean. Deep-Sea Research I 40(6), 1131-1140, doi:10.1016/0967-0637(93)90129-Q.

Alldredge, A.L., Silver, M.W., 1988. Characteristics, dynamics and significance of marine snow. Progress in Oceanography 20(1), 41-82, doi:10.1016/0079-6611(88)90053-5.

Aller, J.Y., Kuznetsova, M.R., Jahns, C.J., Kemp, P.F., 2005. The sea surface microlayer as a source of viral and bacterial enrichment in marine aerosols. Journal of Aerosol Science 36(5-6), 801-812, doi:10.1016/j.jaerosci.2004.10.012.

Alonso-González, I.J., Arístegui, J., Lee, C., Sanchez-Vidal, A., Calafat, A., Fabrés, J., Sangrá, P., Masqué, P., Hernández-Guerra, A., Benítez-Barrios, V., 2010. Role of slowly settling particles in the ocean carbon cycle. Geophysical Research Letters 37(13), L13608, doi:10.1029/2010GL043827.

Alonso-Saez, L., Vazquez-Dominguez, E., Cardelus, C., Pinhassi, J., Sala, M., Lekunberri, I., Balague, V., VilaCosta, M., Unrein, F., Massana, R., Simo, R., Gasol, J.M., 2008. Factors controlling the year-round variability in carbon flux through bacteria in a coastal marine system. Ecosystems 11(3), 397-409, doi:10.1007/s10021-008-9129-0.

Amador, J.A., Alexander, M., Zika, R.G., 1989. Sequential photochemical and microbial degradation of organic molecules bound to humic acid. Applied and Environmental Microbiology 55(11), 2843-2849.

Amon, R.M.W., Benner, R., 1994. Rapid cycling of high-molecular-weight dissolved organic matter in the ocean. Nature 369(6481), 549-552, doi:10.1038/369549a0.

Armstrong, R.A., Lee, C., Hedges, J.I., Honjo, S., Wakeham, S.G., 2002. A new mechanistic model for organic carbon fluxes in the ocean based on the quantitative association of POC with ballast minerals. Deep-Sea Research II 49(1-3), 219-236, doi:10.1016/S0967-0645(01)00101-1.

Armstrong, R.A., Peterson, M.L., Lee, C., Wakeham, S.G., 2009. Settling velocity spectra and the ballast ratio hypothesis. Deep-Sea Research II 56(18), 1470-1478, doi:10.1016/j.dsr2.2008.11.032.

Arrigo, K.R., 2007. Marine manipulations. Nature 450(7169), 591-592, doi:10.1038/450491a.

Asher, W.E., 1997. The sea-surface microlayer and its effects on global air-sea gas transfer. In: Liss, P.S., Duce, R.A. (Eds.), The Sea Surface and Global Change. Cambridge Univ. Press, New York, pp. 251-286.

Asper, V.L., 1987. Measuring the flux and sinking speed of marine snow aggregates. Deep-Sea Research A 34(1), 1-17, doi:10.1016/0198-0149(87)90117-8.

Asper, V.L., Smith, Jr. W.O., 1999. Particle fluxes during austral spring and summer in the southern Ross Sea, Antarctica. Journal of Geophysical Research 104(C3), 5345-5359, doi:10.1029/1998JC900067.

Azetsu-Scott, K., Johnson, B.D., 1994. Time series of the vertical distribution of particles during a spring phytoplankton bloom in a coastal basin. Continental Shelf Research 14(6), 687-705, doi:10.1016/02784343(94)90113-9.

Azetsu-Scott, K., Niven, S.E.H., 2005. The role of transparent exopolymer particles (TEP) in the transport of Th234 in coastal water during a spring bloom. Continental Shelf Research 25(9), 1133-1141, doi:10.1016/j.csr.2004.12.013.

Azetsu-Scott, K., Passow, U., 2004. Ascending marine particles: Significance of transparent exopolymer particles (TEP) in the upper ocean. Limnology and Oceanography 49(3), 741-748, doi:10.4319/lo.2004.49.3.0741. 
Baines, S.B., Pace, M.L., 1991. The production of dissolved organic matter by phytoplankton and its importance to bacteria: Patterns across marine and freshwater systems. Limnology and Oceanography 36(6), 1078-1090, doi:10.4319/lo.1991.36.6.1078.

Banse, K., 1994. Uptake of inorganic carbon and nitrate by marine plankton and the Redfield ratio. Global Biogeochemical Cycles 8(1), 81-84, doi:10.1029/93GB02865.

Bao, K., Shen, J., Wang, G., Gao, C., 2015. Anthropogenic black carbon emission increase during the last 150 years at coastal Jiangsu, China. PLoS One 10(7), e0129680, doi:10.1371/journal.pone.0129680.

Bartoli, G., Migon, C., Losno, R., 2005. Atmospheric input of dissolved inorganic phosphorus and silicon to the coastal northwestern Mediterranean Sea: fluxes, variability and possible impact on phytoplankton dynamics. Deep-Sea Research I 52(11), 2005-2016, doi:10.1016/j.dsr.2005.06.006.

Bates, N.R., Michaels, A.F., Knap, A.H., 1996. Seasonal and interannual variability of oceanic carbon dioxide species at the US JGOFS Bermuda Atlantic Time-series Study (BATS) site. Deep-Sea Research II 43(2-3), 347-383, doi:10.1016/0967-0645(95)00093-3.

Behrenfeld, M., Boss, E., Siegel, D.A., Shea, D.M., 2005. Carbon-based ocean productivity and phytoplankton physiology from space. Global Biogeochemical Cycles 19(1), doi:10.1029/2004GB002299.

Behrenfeld, M., O’Malley, R., Siegel, D., McClain, C.R., Sarmiento, J.L., Feldman, G.C., Milligan, A.J., Falkowski, P.G., Letelier, R.M., Boss, E.S., 2006. Climate-driven trends in contemporary ocean productivity. Nature 444(7120), 752-755, doi:10.1038/nature05317.

Belkin, I.M., 2009. Rapid warming of large marine ecosystems. Progress in Oceanography 81(1-4), 207-213, doi:10.1016/j.pocean.2009.04.011.

Benner, R., Biddanda, B., 1998. Photochemical transformations of surface and deep marine dissolved organic matter: Effects on bacterial growth. Limnology and Oceanography 43(6), 1373-1378, doi:10.4319/lo.1998.43.6.1373.

Benner, R., Pakulski, J.D., McCarthy, M., Hedges, J.I., Hatcher, P.G., 1992. Bulk Chemical Characteristics of Dissolved Organic Matter in the Ocean. Science 255(5051), 1561-1564, doi:10.1126/science.255.5051.1561.

Biddanda, B., Benner, R., 1997. Carbon, nitrogen, and carbohydrate fluxes during the production of particulate and dissolved organic matter by marine phytoplankton. Limnology and Oceanography 42(3), 506-518.

Biermann, A., Engel, A., Riebesell, U., 2014. Changes in organic matter cycling in a plankton community exposed to warming under different light intensities. Journal of Plankton Research 36(3), 658-671, doi:10.1093/plankt/fbu005.

Bijma, J., Pörtner, H.-O., Yesson, C., Rogers, A.D., 2013. Climate change and the oceans - What does the future hold? Marine Pollution Bulletin 74(2), 495-505, doi:10.1016/j.marpolbul.2013.07.022.

Billen, G., Fontigny, A., 1987. Dynamics of Phaeocystis dominated spring bloom in Belgian coastal waters. II. Bacterioplankton dynamics. Marine Ecology Progress Series 37(2-3), 249-257, doi:10.3354/meps037249.

Blauw, A.N., Los, F.J., Huisman, J., Peperzak, L., 2010. Nuisance foam events and Phaeocystis globosa blooms in Dutch coastal waters analyzed with fuzzy logic. Journal of Marine Systems 83(3-4), 115-126, doi:10.1016/j.jmarsys.2010.05.003.

Bongiorni, L., Armeni, M., Corinaldesi, C., Dell'Anno, A., Pusceddu, A., Danovaro, R., 2007. Viruses, prokaryotes and biochemical composition of organic matter in different types of mucilage aggregates. Aquatic Microbial Ecology 49(1), 15-23, doi:10.3354/ame01126.

Boyd, P.W., Jickells, T., Law, C.S., Blain, S., Boyle, E.A., Buesseler, K.O., Coale, K.H., Cullen, J.J., de Baar, H.J.W., Follows, M., Harvey, M., Lancelot, C., Levasseur, M., Owens, N.P.J., Pollard, R., Rivkin, R.B., Sarmiento, J., Schoemann, V., Smetacek, V., Takeda, S., Tsuda, A., Turner, S., Watson, A.J., 2007. Mesoscale iron enrichment experiments 1993-2005: Synthesis and future directions. Science 315(5812), 612-617, doi:10.1126/science.1131669.

Boyd, P.W., Law, C.S., 2001. The Southern Ocean Iron RElease Experiment (SOIREE)—introduction and summary. Deep-Sea Research II 48(11-12), 2425-2438, doi:10.1016/S0967-0645(01)00002-9.

Boyd, P.W., Strzepek, R., Takeda, S., Jackson, G.A., Wong, C.S., McRay, R.M., Law, C., Kiyosawa, H., Saito, H., Sherry, N., Johnson, K., Gower, J., Ramaiah, N., 2005. The evolution and termination of an iron-induced mesoscale bloom in the northeast subarctic Pacific. Limnology and Oceanography 50(6), 1872-1886, doi:10.4319/lo.2005.50.6.1872. 
Boyd, P.W., Watson, A.J., Law, C.S., Abraham, E.R., Trull, T., Murdoch, R., Bakker, D.C.E., Bowie, A.R., Buesseler, K.O., Chang, H., Charette, M., Croot, P., Downing, K., Frew, R., Gall, M., Hadfield, M., Hall, J., Harvey, M., Jameson, G., LaRoche, J., Liddicoat, M., Ling, R., Maldonado, M.T., McKay, M.R., Nodder, S., Pickmere, S., Pridmore, R., Rintoul, S., Safi, K., Sutton, P., Strzepek, R., Tanneberger, K., Turner, S., Waite, A., Zeldis, J., 2000. A mesoscale phytoplankton bloom in the polar Southern Ocean stimulated by iron fertilization. Nature 407(6805), 695-702, doi:10.1038/35037500.

Buesseler, K.O., 1998. The decoupling of production and particulate export in the surface ocean. Global Biogeochemical Cycles 12(2), 297-310, doi:10.1029/97GB03366.

Buesseler, K.O., Barber, R.T., Dickson, M.-L., Hiscock, M.R., Moore, J.K., Sambrotto, R., 2003. The effect of marginal ice-edge dynamics on production and export in the Southern Ocean along $170^{\circ} \mathrm{W}$. Deep-Sea Research II 50(3-4), 579-603, doi:10.1016/S0967-0645(02)00585-4.

Burd, A.B., Jackson, G.A., 2009. Particle aggregation. Annual Review of Marine Science 1, 65-90, doi:10.1146/annurev.marine.010908.163904.

Caldeira, K., 2007. What corals are dying to tell us about $\mathrm{CO}_{2}$ and ocean acidification. Oceanography 20(2), $188-195$

Caldeira, K., Wickett, M.E., 2003. Anthropogenic carbon and ocean pH. Nature 425(6956), 365, doi:10.1038/425365a.

Calleja, M.L., Duarte, C.M., Prairie, Y.T., Agusti, S., Herndl, G.J., 2009. Evidence for surface organic matter modulation of air-sea $\mathrm{CO}_{2}$ gas exchange. Biogeosciences 6(6), 1105-1114.

Cao, L., Caldeira, K., 2008. Atmospheric $\mathrm{CO}_{2}$ stabilization and ocean acidification. Geophysical Research Letters 35(19), L19609, doi:10.1029/2008GL035072.

Carlson, C.A., Ducklow, H.W., Michaels, A.F., 1994. Annual flux of dissolved organic carbon from the euphotic zone in the northwestern Sargasso Sea. Nature 371(6496), 405-408, doi:10.1038/371405a0.

Carr, M.E., Friedrichs, M.A.M., Schmeltz, M., Aita, M.N., Antoine, D., Arrigo, K.R., Asanuma, I., Aumont, O., Barber, R., Behrenfeld, M., Bidigare, R., Buitenhuis, E.T., Campbell, J., Ciotti, A., Dierssen, H., Dowell, M., Dunne, J., Esaias, W., Gentili, B., Gregg, W., Groom, S., Hoepffner, N., Ishizaka, J., Kameda, T., Le Quere, C., Lohrenz, S., Marra, J., Melin, F., Moore, K., Morel, A., Reddy, T.E., Ryan, J., Scardi, M., Smyth, T., Turpie, K., Tilstone, G., Waters, K., Yamanaka, Y., 2006. A comparison of global estimates of marine primary production from ocean color. Deep-Sea Research II 53(5-7), 741-770, doi:10.1016/j.dsr2.2006.01.028.

Carstensen, J., Conley, D., Müller-Karulis, B., 2003. Spatial and temporal resolution of carbon fluxes in a shallow coastal ecosystem, the Kattegat. Marine Ecology Progress Series 252, 35-50, doi:10.3354/meps252035.

Chin, W., Orellana, M.W., Verdugo, P., 1998. Spontaneous assembly of marine dissolved organic matter into polymer gels. Nature 391(6667), 568-570, doi:10.1038/35345.

Chow, J.S., Lee, C., Engel, A., 2015. The influence of extracellular polysaccharides, growth rate, and free coccoliths on the coagulation efficiency of Emiliania huxleyi. Marine Chemistry 175, 5-17, doi:10.1016/j.marchem.2015.04.010.

Cisternas-Novoa, C., Lee, C., Engel, A., 2015. Transparent exopolymer particles (TEP) and Coomassie stainable particles (CSP): Differences between their origin and vertical distributions in the ocean. Marine Chemistry 175, 56-71, doi:10.1016/j.marchem.2015.03.009.

Claquin, P., Probert, I., Lefebvre, S., Veron, B., 2008. Effects of temperature on photosynthetic parameters and TEP production in eight species of marine microalgae. Aquatic Microbial Ecology 51(1), 1-11, doi:10.3354/ame01187.

Coale, K.H., Johnson, K.S., Fitzwater, S.E., Gordon, R.M., Tanner, S., Chavez, F.P., Ferioli, L., Sakamoto, C., Rogers, P., Millero, F., Steinberg, P., Nightingale, P., Cooper, D., Cochlan, W.P., Landry, M.R., Constantinou, J., Rollwagen, G., Trasvina, A., Kudela, R., 1996. A massive phytoplankton bloom induced by an ecosystem-scale iron fertilization experiment in the equatorial Pacific Ocean. Nature 383(6600), 495-501, doi: $10.1038 / 383495 \mathrm{a} 0$.

Codispoti, L.A., Friederich, G.E., Hood, D.W., 1986. Variability in the inorganic carbon system over the southeastern Bearing Sea shelf during spring 1980 and spring-summer 1981. Continental Shelf Research 5(12), 133-160, doi:10.1016/0278-4343(86)90013-0. 
Collins, M., Knutti, R., Arblaster, J., Dufresne, J.-L., Fichefet, T., Friedlingstein, P., Gao, X., Gutowski, W., Johns, T., Krinner, G., Shongwe, M., Tebaldi, C., Weaver, A., Wehner, M., 2013. Long-term climate change: Projections, commitments and irreversibility. In: Stocker, T.F., Qin, D., Plattner, G-.K., Tignor, M., Allen, S.K., Boschung, J., Nauels, A., Xia, Y., Bex, V., Midgley, P.M. (Eds.), Climate Change 2013: The Physical Science Basis Contribution of Working Group I to the Fifth Assessment Report of the Intergovernmental Panel on Climate Change. Cambridge University Press, Cambridge, United Kingdom and New York, NY, USA.

Copin-Montégut, C., 2000. Consumption and production on scales of a few days of inorganic carbon, nitrate and oxygen by the planktonic community: results of continuous measurements at the Dyfamed Station in the northwestern Mediterranean Sea (May 1995). Deep-Sea Research I 47(3), 447-477, doi:10.1016/S09670637(99)00098-9.

Copin-Montégut, G., Avril, B., 1993. Vertical distribution and temporal variation of dissolved organic carbon in the North-Western Mediterranean Sea. Deep-Sea Research I 40(10), 1963-1972, doi:10.1016/09670637(93)90041-Z.

Crawford, G.B., Farmer, D.M., 1987. On the spatial distribution of ocean bubbles. Journal of Geophysical Research 92(C8), 8231-8243, doi:10.1029/JC092iC08p08231.

Crocker, K.M., Passow, U., 1995. Differential aggregation of diatoms. Marine Ecology Progress Series 117(1-3), 249-257, doi:10.3354/meps117249.

Croot, P.L., Passow, U., Assmy, P., Jansen, S., Strass, V.H., 2007. Surface active substances in the upper water column during a Southern Ocean Iron Fertilization Experiment (EIFEX). Geophysical Research Letters 34(3), L03612, doi:10.1029/2006GL028080.

Culver, M.E., Smith, W.O., 1989. Effects of environmental variation on sinking rates of marine phytoplankton. Journal of Phycology 25(2), 262-270, doi:10.1111/j.1529-8817.1989.tb00122.x.

Cunliffe, M., Engel, A., Frka, S., Gašparović, B., Guitart, C., Murrell, J.C., Salter, M., Stolle, C., UpstillGoddard, R., Wurl, O., 2013. Sea surface microlayers: A unified physicochemical and biological perspective of the air-ocean interface. Progress in Oceanography 109, 104-116, doi:10.1016/j.pocean.2012.08.004.

Cunliffe, M., Murrell, J.C., 2009. The sea-surface microlayer is a gelatinous biofilm. The ISME Journal 3(9), 1001-1003, doi:10.1038/ismej.2009.69.

Cunliffe, M., Salter, M., Mann, P.J., Whiteley, A.S., Upstill-Goddard, R.C., Colin Murrell, J., 2009. Dissolved organic carbon and bacterial populations in the gelatinous surface microlayer of a Norwegian fjord mesocosm. FEMS Microbiology Letters 299(2), 248-254, doi: 10.1111/j.1574-6968.2009.01751.x.

Dam, H.G., Drapeau, D.T., 1995. Coagulation efficiency, organic-matter glues and the dynamics of particles during a phytoplankton bloom in a mesocosm study. Deep-Sea Research II 42(1), 111-123, doi:10.1016/0967-0645(95)00007-D.

Dandonneau, Y., Menkes, C., Duteil, O., Gorgues, T., 2008. Concentration of floating biogenic material in convergence zones. Journal of Marine Systems 69(3-4), 226-232, doi:10.1016/j.jmarsys.2006.02.016.

Danovaro, R., Fonda Umani, S., Pusceddu, A., 2009. Climate change and the potential spreading of marine mucilage and microbial pathogens in the Mediterranean Sea. PLoS One 4, e7006, doi:10.1371/journal.pone.0007006.

Decho, A.W., 1990. Microbial exopolymer secretions in ocean environments: their role(s) in food webs and marine processes. Oceanography and Marine Biology 28, 73-153.

De La Rocha, C., Passow, U., 2007. Factors influencing the sinking of POC and the efficiency of the biological carbon pump. Deep-Sea Research II 54(5-7), 639-658, doi:10.1016/j.dsr2.2007.01.004.

Deuser, W.G., Muller-Karger, F.E., Evans, R.H., Brown, O.B., Esaias, W.E., Feldman, G.C., 1990. Surfaceocean color and deep-ocean carbon flux: how close a connection? Deep-Sea Research A 37(8), 1331-1343, doi:10.1016/0198-0149(90)90046-X.

Doney, S., Fabry, V., Feely, R., Kleypas, J., 2009. Ocean acidification: the other $\mathrm{CO}_{2}$ problem. Annual Review of Marine Science 1, 169-192, doi:10.1146/annurev.marine.010908.163834.

Eberlein, K., Leal, M.T., Hammer, K.D., Hickel, W., 1985. Dissolved organic substances during a Phaeocystis pouchetii bloom in the German Bight (North Sea). Marine Biology 89(3), 311-316, doi:10.1007/BF00393665. 
Ebling, A.M., Landing, W.M., 2015. Sampling and analysis of the sea surface microlayer for dissolved and particulate trace elements. Marine Chemistry 177(1), 134-142, doi:10.1016/j.marchem.2015.03.012.

Egge, J.K., Thingstad, T.F., Larsen, A., Engel, A., Wohlers, J., Bellerby, R.G.J., Riebesell, U., 2009. Primary production during nutrient-induced blooms at elevated $\mathrm{CO}_{2}$ concentrations. Biogeosciences 6(5), 877-885.

Elimelech, M., Gregory, J., Jia, X., Williams, R.A., 1995. Particle Deposition and Aggregation: Measurement, Modelling, and Simulation (Butterworth-Heinemann, Woburn, MA, USA).

Endres, S., Galgani, L., Riebesell, U., Schulz, K.-G., Engel, A., 2014. Stimulated bacterial growth under elevated $p \mathrm{CO}_{2}$ : Results from an off-shore mesocosm study. PLoS One 9(6), doi:10.1371/journal.pone.0099228.

Engel, A., 2000. The role of transparent exopolymer particles (TEP) in the increase in apparent particle stickiness $(\alpha)$ during the decline of a diatom bloom. Journal of Plankton Research 22(3), 485-497, doi:10.1093/plankt/22.3.485.

Engel, A., 2002. Direct relationship between $\mathrm{CO}_{2}$ uptake and transparent exopolymer particles production in natural phytoplankton. Journal of Plankton Research 24(1), 49-53, doi:10.1093/plankt/24.1.49.

Engel, A., Delille, B., Jacquet, S., Riebesell, U., Rochelle-Newall, E., Terbruggen, A., Zondervan, I., $2004 a$. Transparent exopolymer particles and dissolved organic carbon production by Emiliania huxleyi exposed to different $\mathrm{CO}_{2}$ concentrations: A mesocosm experiment. Aquatic Microbial Ecology 34(1), 93-104, doi:10.3354/ame034093.

Engel, A., Galgani, L., 2016. The organic sea-surface microlayer in the upwelling region off the coast of Peru and potential implications for air-sea exchange processes. Biogeosciences 13, 989-1007, doi:10.5194/bg-13989-2016.

Engel, A., Händel, N., Wohlers, J., Lunau, M., Grossart, H.-P., Sommer, U., Riebesell, U., 2011. Effects of sea surface warming on the production and composition of dissolved organic matter during phytoplankton blooms: results from a mesocosm study. Journal of Plankton Research 33(3), 357-372, doi:10.1093/plankt/fbq122.

Engel, A., Passow, U., 2001. Carbon and nitrogen content of transparent exopolymer particles (TEP) in relation to their Alcian Blue adsorption. Marine Ecology Progress Series 219, 1-10, doi:10.3354/meps219001.

Engel, A., Piontek, J., Grossart, H.-P., Riebesell, U., Schulz, K.G., Sperling, M., 2014. Impact of $\mathrm{CO}_{2}$ enrichment on organic matter dynamics during nutrient induced coastal phytoplankton blooms. Journal of Plankton Research 36(3), 641-657, doi:10.1093/plankt/fbt125.

Engel, A., Schartau, M., 1999. Influence of transparent exopolymer particles (TEP) on sinking velocity of Nitzschia closterium aggregates. Marine Ecology Progress Series 182, 69-76, doi:10.3354/meps182069.

Engel, A., Thoms, S., Riebesell, U., Rochelle-Newall, E., Zondervan, I., 2004b. Polysaccharide aggregation as a potential sink of marine dissolved organic carbon. Nature 428, 929-932, doi:10.1038/nature02453.

Fabricius, K.E., Wild, C., Wolanski, E., Abele, D., 2003. Effects of transparent exopolymer particles and muddy terrigenous sediments on the survival of hard coral recruits. Estuarine, Coastal and Shelf Science 57(4), 613621, doi:10.1016/S0272-7714(02)00400-6.

Fernandez, M., Bianchi, M., Van Wambeke, F., 1994. Bacterial biomass, heterotrophic production and utilization of dissolved organic matter photosynthetically produced in the Almeria-Oran front. Journal of Marine Systems 5, 313-325, doi:10.1016/0924-7963(94)90053-1.

Fischer, G., Karakas, G., 2009. Sinking rates and ballast composition of particles in the Atlantic Ocean: implications for the organic carbon fluxes to the deep ocean. Biogeosciences 6(1), 85-102.

Fleischmann, E.M., 1989. The measurement and penetration of ultraviolet radiation into tropical marine water. Limnology and Oceanography 34(8), 1623-1629.

Frew, N.M., 2005. The role of organic films in air-sea gas exchange. In: Liss, P.S., Duce, R.A. (Eds.), The Sea Surface and Global Change. Cambridge University Press, Cambridge, pp. 121-172.

Frew, N.M., Goldman, J.C., Dennett, M.R., Johnson, A.S., 1990. Impact of phytoplankton-generated surfactants on air-sea gas exchange. Journal of Geophysical Research 95, 3337-3352, doi:10.1029/JC095iC03p03337.

Frew, N.M., Nelson, R.K., McGillis, W.R., Bock, E.J., Edson, J.B., Hara, T., 2002. Spatial variations in surface microlayer surfactants and their role in modulating air-sea exchange. In: Donelan, M.A., Drennan, W.M., 
Saltzman, E.S., Wannikhof, R. (Eds.), Gas Transfer at Water Surfaces. In: Geophys. Monogr. Ser., vol. 127. AGU, Washington, D.C., pp. 153-159.

Fogg, G.E., 1983. The ecological significance of extracellular products of phytoplankton photosynthesis. Botanica Marina 26(1), 3-14, doi:10.1515/botm.1983.26.1.3.

Fowler, S.W., Knauer, G.A., 1986. Role of large particles in the transport of elements and organic compounds though the oceanic water column. Progress in Oceanography 16(3), 147-194, doi:10.1016/00796611(86)90032-7.

Fukao, T., Kimoto, K., Kotani, Y., 2012. Effect of temperature on cell growth and production of transparent exopolymer particles by the diatom Coscinodiscus granii isolated from marine mucilage. Journal of Applied Phycology 24, 181-186, doi:10.1007/s10811-011-9666-3.

Gaerdes, A., Iversen, M.H., Grossart, H.-P., Passow, U., Ullrich, M., 2011. Diatom associated bacteria are required for aggregation of Thalassiosira weissflogii. ISME Journal 5, 436-445, doi:10.1038/ismej.2010.145.

Galgani, L., Stolle, C., Endres, S., Schulz, K.G., Engel, A., 2014. Effects of ocean acidification on the biogenic composition of the sea-surface microlayer: Results from a mesocosm study. Journal of Geophysical Research: Oceans 119, doi:10.1002/ 2014JC010188.

Gao, Q., Leck, C., Rauschenberg, C., Matrai, P.A., 2012. On the chemical dynamics of extracellular polysaccharides in the high Arctic surface microlayer. Ocean Science 8(4), 401-418, doi:10.5194/os-8-4012012.

Gašparović, B., Ćosović, B., 2001. Distribution of surface-active substances in the northern Adriatic Sea. Marine Chemistry 75, 301-313, doi:10.1016/S0304-4203(01)00044-5.

Gašparović, B., Ćosović, B., Vojvodić, V., 1998b. Contribution of organic acids to the pool of surface active substances in model and marine samples using o-nitrophenol as an electrochemical probe. Organic Geochemistry 29, 1025-1032, doi:10.1016/S0146-6380(98)00055-2.

Gašparović, B., Plavai, M., Ćosović, B., Saliot, A., 2007. Organic matter characterization in the sea surface microlayers in the subarctic Norwegian fjords region. Marine Chemistry 105, 1-14, doi:10.1016/j.marchem.2006.12.010.

Gašparović, B., Vojvodić, V., Ćosović, B., 1998a. Excretion of organic matter during an experimental phytoplankton bloom followed using o-nitrophenol as an electrochemical probe. Croatica Chemica Acta 71(2), 271-284.

Giani, M., Berto, D., Zangrando, V., Castelli, S., Sist, P., Urbani, R., 2005. Chemical characterization of different typologies of mucilaginous aggregates in the Northern Adriatic Sea. Science of the Total Environment 353(1-3), 232-246, doi:10.1016/j.scitotenv.2005.09.027.

Gibbs, R.J., 1983. Effect of natural organic coatings on the coagulation of particles. Environmental Science \& Technology 17(4), 237-240, doi:10.1021/es00110a011.

Giordano, M., Davis, J.S., Bowes, G., 1994. Organic carbon release by Dunaliella salina (chlorophyta) under different growth conditions of $\mathrm{CO}_{2}$, nitrogen, and salinity. Journal of Phycology 30(2), 249-257, doi:10.1111/j.0022-3646.1994.00249.x.

Grossart, H.-P., Simon, M., Logan, B.E., 1997. Formation of macroscopic organic aggregates (lake snow) in a large lake: the significance of transparent exopolymer particles, phytoplankton, and zooplankton. Limnology and Oceanography 42(8), 1651-1659, doi:10.4319/lo.1997.42.8.1651.

Guillard, R.R., Hellebust, J.H., 1971. Growth and production of extracellular substances by two strains of Phaeocystis pouchetii. Journal of Phycology 7, 330-338, doi:10.1111/j.1529-8817.1971.tb01528.x.

Hamanaka, J., Tanoue, E., Hama, T., Handa, N., 2002. Production and export of particulate fatty acids, carbohydrates and combined amino acids in the euphotic zone. Marine Chemistry 77(1), 55-69, doi:10.1016/S0304-4203(01)00075-5.

Hannon, E., Boyd, P.W., Silvoso, M., Lancelot, C., 2001. Modeling the bloom evolution and carbon flows during SOIREE: Implications for future in situ iron-enrichments in the Southern Ocean. Deep-Sea Research II 48(11-12), 2745-2773, doi:10.1016/S0967-0645(01)00016-9.

Hansell, D.A., Waterhouse, T.Y., 1997. Controls on the distribution of organic carbon and nitrogen in the eastern Pacific Ocean. Deep-Sea Research I 44(5), 843-857, doi:10.1016/S0967-0637(96)00128-8. 
Hansen, J.L.S., Kiørboe, T., 1997. Quantifying interspecific coagulation efficiency of phytoplankton. Marine Ecology Progress Series 159, 75-79, doi:10.3354/meps159075.

Harvey, H.R., Tuttle, J.H., Bell, J.T., 1995. Kinetics of phytoplankton decay during simulated sedimentation: changes in biochemical composition and microbial activity under oxic and anoxic conditions. Geochimica et Cosmochimica Acta 59(16), 3367-3377, doi:10.1016/0016-7037(95)00217-N.

Heimbürger, L.-E., Cossa, D., Marty, J.C., Migon, C., Averty, B., Dufour, A., Ras, J., 2010. Methyl mercury distributions in relation with nano- and picophytoplankton in an oceanic water column (Ligurian Sea, Northwestern Mediterranean). Geochimica et Cosmochimica Acta 74(19), 5549-5559, doi:10.1016/j.gca.2010.06.036

Heimbürger, L.-E., Migon, C., Losno, R., Miquel, J.-C., Thibodeau, B., Stabholz, M., Dufour, A., Leblond, N., 2014. Vertical export flux of metals in the Mediterranean Sea. Deep-Sea Research I 87, 14-23, doi:10.1016/j.dsr.2014.02.001.

Herndl, G.J., Peduzzi, P., 1988. The ecology of amorphous aggregations (marine snow) in the northern Adriatic sea: I. General considerations. Marine Ecology 9(1), 79-90, doi:10.1111/j.1439-0485.1988.tb00199.x.

Hong, Y., Smith, W.O. Jr, White, A.-M., 1997. Studies on transparent exopolymer particles (TEP) produced in the Ross Sea (Antarctica) and by Phaeocystis antarctica (Prymnesiophyceae). Journal of Phycology 33, 368376, doi:10.1111/j.0022-3646.1997.00368.x.

Hunter, K.A., Liss, P.S., 1981. Polarographic measurement of surface-active material in natural waters. Water Research 15(2), 203-215, doi:10.1016/0043-1354(81)90113-5.

Inoue, K., Nishimura, M., Nayak, B.B., Kogure, K., 2007. Separation of Marine Bacteria according to Buoyant Density by Use of the Density-Dependent Cell Sorting Method. Applied and Environmental Microbiology 73(4), 1049-1053, doi:10.1128/AEM.01158-06.

Iversen, M.H., Ploug, H., 2010. Ballast minerals and the sinking carbon flux in the ocean: carbon specific respiration rates and sinking velocity of marine snow aggregates. Biogeosciences 7(9), 2613-2624, doi:10.5194/bg-7-2613-2010.

Jackson, G.A., 1990. A model of the formation to marine algal flocks by physical coagulation processes. DeepSea Research A 37(8), 1197-1211, doi:10.1016/0198-0149(90)90038-W.

Jackson, G.A., 1995. TEP and coagulation during a mesocosm experiment. Deep-Sea Research II 42(1), 215 222, doi:10.1016/0967-0645(95)00015-I.

Jackson, G.A., Burd, A.B., 1998. Aggregation in the marine environment. Environmental Science \& Technology 32(19), 2805-2814, doi:10.1021/es980251w.

Jackson, G.A., Waite, A.M., Boyd, P.W., 2005. Role of algal aggregation in vertical carbon export during SOIREE and in other low biomass environments. Geophysical Research Letters 32(13), L13607, doi:10.1029/2005GL023180.

Jenkinson, I.R., 1986. Oceanographic implications of non-newtonian properties found in phytoplankton cultures. Nature 323(6087), 435-437, doi:10.1038/323435a0.

Jenkinson, I.R., 1993. Bulk-phase viscoelastic properties of seawater. Oceanologica Acta 16(4), 317-334.

Jenkinson, I.R., Biddanda, B.A., 1995. Bulk-phase viscoelastic properties of seawater: relationship with plankton components. Journal of Plankton Research 17(12), 2251-2274, doi:10.1093/plankt/17.12.2251.

Jiang, Q., Logan, B.E., 1991. Fractal dimensions of aggregates determined from steady state size distributions. Environmental Science \& Technology 25(12), 2013-2038, doi: 10.1021/es00024a007.

Johnson, B.D., Zhou, X., Wangersky, P.J., 1986. Surface coagulation in sea water. Netherlands Journal of Sea Research 20(2-3), 201-210, doi:10.1016/0077-7579(86)90042-6.

Jolly, M.W., Cochrane, M.A., Freeborn, P.H., Holden, Z.A., Brown, T.J., Williamson, G.J., Bowman, D.M.J.S., 2014. Climate-induced variations in global wildfire danger from 1979 to 2013. Nature Communications 6,7537, doi:10.1038/ncomms8537.

Jones, V., Meador, T.B., Gogou, A., Migon, C., Penkman, K.E.H., Collins, M.J., Repeta, D.J., 2013. Characterisation and dynamics of dissolved organic matter in the Northwestern Mediterranean Sea. Progress in Oceanography 119, 78-89, doi:10.1016/j.pocean.2013.06.007. 
Jouon, A., Douillet, P., Ouillon, S., Fraunié, P., 2006. Calculations of hydrodynamic time parameters in a semiopened coastal zone using a 3D hydrodynamic model. Continental Shelf Research 26(12-13), 1395-1415, doi:10.1016/j.csr.2005.11.014.

Karavoltsos, S., Kalambokis, E., Sakellari, A., Plavšić, M., Dotsika, E., Karalis, P., Leondiadis, L., Dassenakis, M., Scoullos, M., 2015. Organic matter characterization and copper complexing capacity in the sea surface microlayer of coastal areas of the Eastern Mediterranean. Marine Chemistry 173, 234-243, doi:10.1016/j.marchem.2014.12.004.

Karl, D.M., Christian, J.R., Dore, J.E., Hebel, D.V., Letelier, R.M., Tupas, L.M., Winn, C.D., 1996. Seasonal and interannual variability in primary production and particle flux at Station ALOHA. Deep-Sea Research II 43(2-3), 539-568, doi:10.1016/0967-0645(96)00002-1.

Karl, D.M., Hebel, D.V., Bjorkman, K., Letelier, R.M., 1998. The role of dissolved organic matter release in the productivity of the oligotrophic North Pacific Ocean. Limnology and Oceanography 43(6), 1270-1286.

Kepkay, P.E., Jellett, J.F., Niven, S.E.H., 1997. Respiration and the carbon-to-nitrogen ratio of a phytoplankton bloom. Marine Ecology Progress Series 150(1-3), 249-261, doi:10.3354/meps150249.

Kepkay, P.E., Johnson, B.D., 1989. Coagulation on bubbles allows microbial respiration of oceanic dissolved organic carbon. Nature 338(6210), 63-65, doi:10.1038/338063a0.

Kieber, D.J., McDaniel, J., Mopper, K., 1989. Photochemical source of biological substrates in sea water: implications for carbon cycling. Nature 341(6243), 637-639, doi:10.1038/341637a0.

Kim, J.-M., Lee, K., Shin, K., Yang, E.J., Engel, A., Karl, D.M., Kim, H.-C., 2011. Shifts in biogenic carbon flow from particulate to dissolved forms under high carbon dioxide and warm ocean conditions. Geophysical Research Letters 38, L08612, doi:10.1029/2011GL047346.

Kiørboe, T., Andersen, K.P., Dam, H.G., 1990. Coagulation efficiency and aggregate formation in marine phytoplankton. Marine Biology 107(2), 235-246, doi:10.1007/BF01319822.

Kiørboe, T., Hansen, J.L.S., 1993. Phytoplankton aggregate formation: observations of patterns and mechanisms of cell sticking and the significance of exopolymeric material. Journal of Plankton Research 15(9), 993-1018, doi:10.1093/plankt/15.9.993.

Kiørboe, T., Lundsgaard, C., Olesen, M., Hansen, J.L.S., 1994. Aggregation and sedimentation processes during a spring phytoplankton bloom: A field experiment to test coagulation theory. Journal of Marine Research 52(2), 297-323, doi:10.1357/0022240943077145.

Kiørboe, T., Tiselius, P., Mitchell-Innes, B., Hansen, J.L.S., Visser, A.W., Mari, X., 1998. Intensive aggregate formation with low vertical flux during an upwelling-induced diatom bloom. Limnology and Oceanography 43(1), 104-116.

Klaas, C., Archer, D.E., 2002, Association of sinking organic matter with various types of mineral ballast in the deep sea: Implications for the rain ratio. Global Biogeochemical Cycles 16(4), 1116, doi:10.1029/2001GB001765.

Koch, B.P., Kattner, G., Witt, M., Passow, U., 2014. Molecular insights into the microbial formation of marine dissolved organic matter: recalcitrant or labile? Biogeosciences 11(15), 4173-4190, doi:10.5194/bg-11-41732014.

Körtzinger, A., Koeve, W., Kähler, P., Mintrop, L., 2001. C:N ratios in the mixed layer during the productive season in the northeast Atlantic Ocean. Deep-Sea Research I 48(3), 661-688, doi:10.1016/S09670637(00)00051-0.

Kovac, N., Faganeli, J., Bajt, O., Sket, B., Orel, B., Penna, N., 2004. Chemical composition of macroaggregates in the northern Adriatic sea. Organic Geochemistry 35(10), 1095-1104, doi:10.1016/j.orggeochem.2004.06.005.

Kovac, N., Faganeli, J., Sket, B., Bajt, O., 1998. Characterization of macroaggregates and photodegradation of their water soluble fraction. Organic Geochemistry 29(5-7), 1623-1634, doi:10.1016/S0146-6380(98)001788.

Kuznetsova, M., Lee, C., Aller, J., 2005. Characterization of the proteinaceous matter in marine aerosols. Marine Chemistry 96(3-4), 359-377, doi:10.1016/j.marchem.2005.03.007.

Kwon, E.Y., Primeau, F., Sarmiento, J.L., 2009. The impact of remineralization depth on the air-sea carbon balance. Nature Geoscience 2(9), 630-635, doi:10.1038/NGEO612. 
Lancelot, C., Mathot, S., 1985. Biochemical fractionation of primary production by phytoplankton in Belgian coastal waters during short- and long-term incubations with 14C-bicarbonate. 2. Phaeocystis poucheti colonial population. Marine Biology 86(3), 227-232, doi:10.1007/BF00397508.

Laws, E.A., Falkowski, P.G., Smith, Jr W.O., Ducklow, H., McCarthy, J.J., 2000. Temperature effects on export production in the open ocean. Global Biogeochemical Cycles 14(4), 1231-1246, doi:10.1029/1999GB001229.

Leck, C., Bigg, A.K., 2005. Biogenic particles in the surface microlayer and overlaying atmosphere in the central Arctic Ocean during summer. Tellus B 57(4), 305-316, doi:10.1111/j.1600-0889.2005.00148.x.

Lee, Z., Hu, C., Shang, S., Du, K., Lewis, M., Arnone, R., Brewin, R., 2013. Penetration of UV-visible solar radiation in the global oceans: Insights from ocean color remote sensing. Journal of Geophysical Research 118(9), 4241-4255, doi:10.1002/jgrc.20308.

Legendre, L., Rivkin, R.B., Weinbauer, M.G., Guidi, L., Uitz, J., 2015. The microbial carbon pump concept: Potential biogeochemical significance in the globally changing ocean. Progress in Oceanography 134, 432450, doi:10.1016/j.pocean.2015.01.008.

Li, X., Leck, C., Sun, L., Hede, T., Tu, Y., Ågren, H., 2013. Cross-linked polysaccharide assemblies in marine gels: An atomistic simulation. Journal of Physical Chemistry Letters 4(16), 2637-2642, doi:10.1021/jz401276r.

Lindell, M.J., Graneli, W., Tranvik, L.J., 1995. Enhanced bacterial growth in response to photochemical transformation of dissolved organic matter. Limnology and Oceanography 40(1), 195-199.

Logan, B.E., Passow, U., Alldredge, A.L., Grossart, H.-P., Simon, M., 1995. Rapid formation and sedimentation of large aggregates is predictable from coagulation rates (half-lives) of transparent exopolymer particles (TEP). Deep-Sea Research II 42(1), 203-214, doi:10.1016/0967-0645(95)00012-F.

Longhurst, A., Sathyendranath, S., Platt, T., Caverhill, C., 1995. An estimate of global primary production in the ocean from satellite radiometer data. Journal of Plankton Research 17(6), 1245-1271, doi:10.1093/plankt/17.6.1245.

Lopez-Sandoval, D.C., Fernandez, A., Maranon, E., 2011. Dissolved and particulate primary production along a longitudinal gradient in the Mediterranean Sea. Biogeosciences 8(3), 815-825, doi:10.5194/bg-8-815-2011.

MacGilchrist, G.A., Shi, T., Tyrrell, T., Richier, S., Moore, C.M., Dumousseaud, C., Achterberg, E.P., 2014. Effect of enhanced $p \mathrm{CO}_{2}$ levels on the production of dissolved organic carbon and transparent exopolymer particles in short-term bioassay experiments. Biogeosciences 11(13), 3695-3706, doi:10.5194/bg-11-36952014.

MacIntyre, S., Alldredge, A.L., Gotschalk, C.C., 1995. Accumulation of marine snow at density discontinuities in the water column. Limnology and Oceanography 40(3), 449-468.

Mahowald, N.M., Kloster, S., Engelstaedter, S., Moore, J.K., Mukhopadhyay, S., McConnell, J.R., Albani, S., Doney, S.C., Bhattacharya, A., Curran, M.A.J., Flanner, M.G., Hoffman, F.M., Lawrence, D.M., Lindsay, K., Mayewski, P.A., Neff, J., Rothenberg, D., Thomas, E., Thornton, P.E., Zender, C.S., 2010. Observed 20th century desert dust variability: Impact on climate and biogeochemistry. Atmospheric Chemistry and Physics 10(22), 10875-10893, doi:10.5194/acp-10-10875-2010.

Mahowald, N.M., Luo, C., 2003. A less dusty future? Geophysical Research Letters 30(17), 1903, doi:10.1029/2003GL017880.

Malits, A., Cattaneo, R., Sintes, E., Gasol, J.M., Herndl, G.J., Weinbauer, M.G., 2015. Potential impacts of black carbon on the marine microbial community. Aquatic Microbial Ecology 75(1), 27-42, doi:10.3354/ame01742.

Marañon, E., Cermeno, P., Fernandez, E., Rodrıuez, J., Zabala, L., 2004. Significance and mechanisms of photosynthetic production of dissolved organic carbon in a coastal eutrophic ecosystem. Limnology and Oceanography 49(5), 1652-1666.

Marchal, O., Monfray, P., Bates, N.R., 1996. Spring-summer imbalance of dissolved inorganic carbon in the mixed layer of the northwestern Sargasso Sea. Tellus B 48(1), 115-135, doi:10.1034/j.16000889.1996.00011.x.

Mari, X., 1999. Carbon content and C:N ratio of transparent exopolymeric particles (TEP) produced by bubbling exudates of diatoms. Marine Ecology Progress Series 183, 59-71, doi:10.3354/meps183059. 
Mari, X., 2008. Does ocean acidification induce an upward flux of marine aggregates? Biogeosciences 5(4), 1023-1031.

Mari, X., Beauvais, S., Lemée, R., Pedrotti, M.L., 2001. Non-Redfield C:N ratio of transparent exopolymeric particles in the northwestern Mediterranean Sea. Limnology and Oceanography 46(7), 1831-1836.

Mari, X., Burd, A.B., 1998. Seasonal size spectra of transparent exopolymeric particles (TEP) in a coastal sea and comparison with those predicted using coagulation theory. Marine Ecology Progress Series 163, 63-76, doi:10.3354/meps 163063 .

Mari, X., Kiørboe, T., 1996. Abundance, size distribution and bacterial colonization of transparent exopolymeric particles (TEP) in the Kattegat. Journal of Plankton Research 18(6), 969-986, doi:10.1093/plankt/18.6.969.

Mari, X., Lefèvre, J., Torréton, J.-P., Bettarel, Y., Pringault, O., Rochelle-Newall, E., Marchesiello, P., Menkes, C., Rodier, M., Migon, C., Motegi, C., Weinbauer, M.G., Legendre, L., 2014. Effects of soot deposition on particle dynamics and microbial processes in marine surface waters. Global Biogeochemical Cycles 28(7), 662-678, doi:10.1002/2014GB004878.

Mari, X., Robert, M., 2008. Metal induced variations of TEP sticking properties in the southwestern lagoon of New Caledonia. Marine Chemistry 110(1-2), 98-108, doi:10.1016/j.marchem.2008.02.012.

Mari, X., Rochelle-Newall, E., Torréton, J.-P., Pringault, O., Jouon, A., Migon, C., 2007. Water residence time: A regulatory factor of the DOM to POM transfer efficiency. Limnology and Oceanography 52(2), 808-819.

Mari, X., Torréton, J.-P., Trinh, C.B.T., Bouvier, T., Chu, V.T., Ouillon, S., Lefebvre, J.-P., 2012. Aggregation dynamics along a salinity gradient in the Bach Dang estuary, North Vietnam. Estuarine, Coastal and Shelf Science 96, 151-158, doi:10.1016/j.ecss.2011.10.028.

Martin, J.H., Coale, K.H., Johnson, K.S., Fitzwater, S.E., Gordon, R.M., Tanner, S.J., Hunter, C.N., Elrod, V.A., Nowicki, J.L., Coley, T.L., Barber, R.T., Lindley, S., Watson, A.J., Van Scoy, K., Law, C.S., Liddicoat, M.I., Ling, R., Stanton, T., Stockel, J., Collins, C., Anderson, A., Bidigare, R., Ondrusek, M., Latasa, M., Millero, F.J., Lee, K., Yao, W., Zhang, J.Z., Friederich, G., Sakamoto, C., Chavez, F., Buck, K., Kolber, Z., Greene, R., Falkowski, P., Chisholm, S.W., Hoge, F., Swift, R., Yungel, J., Turner, S., Nightingale, P., Hatton, A., Liss, P., Tindale, N.W., 1994. Testing the iron hypothesis in ecosystems of the equatorial Pacific Ocean. Nature 371(6493), 123-129, doi:10.1038/371123a0.

Martin, J.H., Knauer, G.A., Karl, D.M., Broenkow, W.W., 1987. VERTEX: Carbon cycling in the northeast Pacific. Deep-Sea Research A 34(2), 267-285, doi:10.1016/0198-0149(87)90086-0.

Martin, P., van der Loeff, M.R., Cassar, N., Vandromme, P., d’Ovidio, F., Stemmann, L., Rengarajan, R., Soares, M., González, H.E., Ebersbach, F., Lampitt, R.S., Sanders, R., Barnett, B.A., Smetacek, V., Naqvi, S.W.A., 2013. Iron fertilization enhanced net community production but not downward particle flux during the Southern Ocean iron fertilization experiment LOHAFEX. Global Biogeochemical Cycles 27(3), 871-881, doi:10.1002/gbc.20077.

Martinussen, I., Thingstad, T.F., 1987. Utilization of N, P and organic C by heterotrophic bacteria. 2. Comparison of experiments and a mathematical model. Marine Ecology Progress Series 37(2-3), 285-293, doi:10.3354/meps037285.

McCarthy, M., Hedges, J., Benner, R., 1996. Major biochemical composition of dissolved high molecular weight organic matter in seawater. Marine Chemistry 55(3-4), 281-297, doi:10.1016/S0304-4203(96)00041-2.

McDonnell, A.M.P., Buesseler, K.O., 2010. Variability in the average sinking velocity of marine particles. Limnology and Oceanography 55(5), 2085-2096, doi:10.4319/lo.2010.55.5.2085.

Meakin, P., 1998. Fractals, Scaling and Growth Far From Equilibrium (Cambridge University Press, Cambridge, UK).

Metcalfe, A.M., Stoll, S., Burd, A.B., 2006. The effect of inhomogeneous stickiness on polymer aggregation. Journal of Colloid and Interface Science 298, 629-638.

Michaels, A.F., Bates, N.R., Buesseler, K.O., Carlson, C.A., Knap, A.H., 1994. Carbon-cycle imbalances in the Sargasso Sea. Nature 372(6506), 537-540, doi:10.1038/372537a0.

Migon, C., Sandroni, V., Marty, J.-C., Gasser, B., Miquel, J.-C., 2002. Transfer of atmospheric matter through the euphotic layer in the northwestern Mediterranean: seasonal pattern and driving forces. Deep-Sea Research II 49(11), 2125-2141, doi:10.1016/S0967-0645(02)00031-0. 
Miquel, J.-C., Martín, J., Gasser, B., Baena, A.R.Y., Toubal, T., Fowler, S.W., 2011. Dynamics of particle flux and carbon export in the northwestern Mediterranean Sea: A two decade time-series study at the DYFAMED site. Progress in Oceanography 91(4), 461-481, doi:10.1016/j.pocean.2011.07.018.

Miller, W.L., Zepp, R.G., 1995. Photochemical production of dissolved inorganic carbon from terrestrial organic matter: Significance to the oceanic organic carbon cycle. Geophysical Research Letters 22(4), 417-420, doi:10.1029/94GL03344.

Miyake, Y., Koizumi, M., 1948. The measurement of the viscosity coefficient of sea water. Journal of Marine Research 7(2), 63-66.

Monahan, E.C., Dam, H.G., 2001. Bubbles: An estimate of their role in the global oceanic flux of carbon. Journal of Geophysical Research 106(C5), 9377-9383, doi:10.1029/2000JC000295.

Mopper, K., Stahovec, W.L., 1986. Sources and sinks of low molecular weight organic carbonyl compounds in seawater. Marine Chemistry 19(4), 305-321, doi:10.1016/0304-4203(86)90052-6.

Mopper, K., Zhou, X.L., Kieber, R.J., Kieber, D.J., Sikorski, R.J., Jones, R.D., 1991. Photochemical degradation of dissolved organic carbon and its impact on the oceanic carbon cycle. Nature 353(6339), 60-62, doi:10.1038/353060a0.

Mopper, K., Zhou, J., Ramana, K.S., Passow, U., Dam, H.G., Drapeau, D.T., 1995. Role of surface-active carbohydrates in the flocculation of a diatom bloom in a mesocosm. Deep-Sea Research II 42(1), 47-73, doi:10.1016/0967-0645(95)00004-A.

Morán, X.A.G., Sebastian, M., Pedros-Alio, C., Estrada, M., 2006. Response of Southern Ocean phytoplankton and bacterioplankton production to short-term experimental warming. Limnology and Oceanography 51(4), 1791-1800.

Morris, D.P., Zagarese, H., Williamson, C.E., Balseiro, E.G., Hargreaves, B.R., Modenutti, B., Moeller, R., Queimalinos, C., 1995. The attenuation of solar UV radiation in lakes and the role of dissolved organic carbon. Limnology and Oceanography 40(8), 1381-1391.

Müller-Niklas, G., Schuster, S., Kaltenböck, E., Herndl, G.J., 1994. Organic content and bacterial metabolism in amorphous aggregations of the northern Adriatic Sea. Limnology and Oceanography 39(1), 58-68.

Myklestad, S.M., 1995. Release of extracellular products by phytoplankton with special emphasis on polysaccharides. Science of the Total Environment 165(1-3), 155-164, doi:10.1016/0048-9697(95)04549-G.

Nagata, T., 2000. Production mechanisms of dissolved organic matter. In: Kirchman, D.L. (Ed.), Microbial Ecology of the Oceans. Wiley-Liss, Inc., New York, pp. 121-152.

Nodder, S.D., Waite, A.M., 2001. Is Southern Ocean organic carbon and biogenic silica export enhanced by iron-stimulated increases in biological production? Sediment trap results from SOIREE. Deep-Sea Research II 48(11-12), 2681-2701, doi:10.1016/S0967-0645(01)00014-5.

Obernosterer, I., Catala, P., Reinthaler, T., Herndl, G.J., Lebaron, P., 2005. Enhanced heterotrophic activity in the surface microlayer of the Mediterranean Sea. Marine Ecology Progress Series 39(3), 293-302, doi:10.3354/ame039293.

Obernosterer, I., Herndl, G.J., 1995. Phytoplankton extracellular release and bacterial growth: dependence on the inorganic N:P ratio. Marine Ecology Progress Series 116(1-3), 247-257, doi:10.3354/meps116247.

Ortega-Retuerta, E., Passow, U., Duarte, C.M., Reche, I., 2009b. Effects of ultraviolet B radiation on (not so) transparent exopolymer particles. Biogeosciences 6(12), 3071-3080.

Ortega-Retuerta, E., Reche, I., Pulido-Villena, E., Agustí, S., Duarte, C.M., 2009a. Uncoupled distributions of transparent exopolymer particles (TEP) and dissolved carbohydrates in the Southern Ocean. Marine Chemistry 115(1-2), 59-65, doi:10.1016/j.marchem.2009.06.004.

Passow, U., 2000. Formation of Transparent Exopolymer Particles, TEP, from dissolved precursor material. Marine Ecology Progress Series 192, 1-11, doi:10.3354/meps192001.

Passow, U., 2002a. Transparent exopolymer particles (TEP) in aquatic environments. Progress in Oceanography 55(3-4), 287-333, doi:10.1016/S0079-6611(02)00138-6.

Passow, U., 2002b. Production of transparent exopolymer particles (TEP) by phyto- and bacterioplankton. Marine Ecology Progress Series 236, 1-12, doi:10.3354/meps236001. 
Passow, U., 2004. Switching perspectives: Do mineral fluxes determine particulate organic carbon fluxes or vice versa? Geochemistry Geophysics Geosystems 5, Q04002, doi:10.1029/2003GC000670.

Passow, U., 2012. The abiotic formation of TEP under different ocean acidification scenarios. Marine Chemistry 128, 72-80, doi:10.1016/j.marchem.2011.10.004.

Passow, U., Alldredge, A.L., 1994. Distribution, size, and bacterial colonization of transparent exopolymer particles (TEP) in the ocean. Marine Ecology Progress Series 113(1-2), 185-198, doi:10.3354/meps 113185

Passow, U., Alldredge, A.L., 1995. A dye-binding assay for the spectrophotometric measurement of transparent exopolymer particles (TEP). Limnology and Oceanography 40(7), 1326-1335.

Passow, U., Alldredge, A.L., Logan, B.E., 1994. The role of particulate carbohydrate exudates in the flocculation of diatom blooms. Deep-Sea Research I 41(2), 335-357, doi:10.1016/0967-0637(94)90007-8.

Passow, U., De La Rocha, C.L., Fairfield, C., Schmidt, K., 2014. Aggregation as a function of $p \mathrm{CO}_{2}$ and mineral particles. Limnology and Oceanography 59(2), 532-547, doi:10.4319/lo.2014.59.2.0532.

Passow, U., Laws, E.A., 2015. Ocean acidification as one of multiple stressors: growth response of Thalassiosira weissflogii (diatom) under temperature and light stress. Marine Ecology Progress Series 541, 75-90, doi:10.3354/meps 11541 .

Passow, U., Shipe, R.F., Murray, A., Pak, D.K., Brzezinski, M.A., Alldredge, A.L., 2001. The origin of transparent exopolymer particles (TEP) and their role in the sedimentation of particulate matter. Continental Shelf Research 21(4), 327-346, doi:10.1016/S0278-4343(00)00101-1.

Passow, U., Wassmann, P., 1994. On the trophic fate of Phaeocystis pouchetii (Hariot). IV. The formation of marine snow by $P$. pouchetii. Marine Ecology Progress Series 104(1-2), 153-161, doi:10.3354/meps104153.

Passow, U., Ziervogel, K., Asper, V., Diercks, A., 2012. Marine snow formation in the aftermath of the Deepwater Horizon oil spill in the Gulf of Mexico. Environmental Research Letters 7 (035031), 11, doi:10.1088/1748-9326/7/3/035301.

Piontek, J., Händel, N., Langer, G., Wohlers, J., Riebesell, U., Engel, A., 2009. Effects of rising temperature on the formation and microbial degradation of marine diatom aggregates. Aquatic Microbial Ecology 54(3), 305-318, doi:10.3354/ame01273.

Piontek, J., Lunau, M., Händel, N., Borchard, C., Wurst, M., Engel, A., 2010. Acidification increases microbial polysaccharide degradation in the ocean. Biogeosciences 7(5), 1615-1624, doi:10.5194/bg-7-1615-2010.

Pitcher, G.C., Walker, D.R., Mitchell-Innes, B.A., Moloney, C.L., 1991. Short-term variability during an Anchor station study in the southern Benguela upwelling system: Phytoplankton dynamics. Progress in Oceanography 28(1-2), 39-64, doi:10.1016/0079-6611(91)90020-M.

Plattner, G.-K., Gruber, N., Frenzel, H., McWilliams, J.C., 2005. Decoupling marine export production from new production. Geophysical Research Letters 32, L11612, doi:10.1029/2005GL022660.

Ploug, H., Iversen, M.H., Fischer, G., 2008. Ballast, sinking velocity, and apparent diffusivity within marine snow and zooplankton fecal pellets: Implications for substrate turnover by attached bacteria. Limnology and Oceanography 53(5), 1878-1886, doi:10.4319/lo.2008.53.5.1878.

Ploug, H., Passow, U., 2007. Direct measurement of diffusivity within diatom aggregates containing transparent exopolymer particles. Limnology and Oceanography 52(1), 1-6.

Prieto, L., Ruiz, J., Echevarria, F., Garcia, C.M., Bartual, A., Galvez, J.A., Corzo, A., Macias, D., 2002. Scales and processes in the aggregation of diatom blooms: high time resolution and wide size range records in a mesocosm study. Deep-Sea Research I 49(7), 1233-1253, doi:10.1016/S0967-0637(02)00024-9.

Pugnetti, A., Armeni, M., Camatti, E., Crevatin, E., Dell'Anno, A., Del Negro, P., Milandri, A., Socal, G., Umani, S.F., Danovaro, R., 2005. Imbalance between phytoplankton production and bacterial carbon demand in relation to mucilage formation in the Northern Adriatic Sea. Science of the Total Environment 353(1-3), 162-177, doi:10.1016/j.scitotenv.2005.09.014.

Pulido-Villena, E., Wagener, T., Guieu, C., 2008. Bacterial response to dust pulses in the western Mediterranean: Implications for carbon cycling in the oligotrophic ocean. Global Biogeochemical Cycles 22(1), GB1020, doi:10.1029/2007GB003091. 
Radic, T., Kraus, R., Fuks, D., Radic, J., Pecar, O., 2005. Transparent exopolymeric particles' distribution in the northern Adriatic and their relation to microphytoplankton biomass and composition. Science of the Total Environment 353(1-3), 151-161, doi:10.1016/j.scitotenv.2005.09.013.

Ramaiah, N., Takeda, S., Furuya, K., Yoshimura, T., Nishioka, J., Aono, T., Nojiri, Y., Imai, K., Kudo, I., Saito, H., Tsuda, A., 2005. Effect of iron enrichment on the dynamics of transparent exopolymer particles in the western subarctic Pacific. Progress in Oceanography 64(2-4), 253-261, doi:10.1016/j.pocean.2005.02.012.

Ramaiah, N., Yoshikawa, T., Furuya, K., 2001. Temporal variations in transparent exopolymer particles (TEP) associated with a diatom spring bloom in a subarctic ria in Japan. Marine Ecology Progress Series 212, 7988, doi:10.3354/meps212079.

Rayner, N.A., Parker, D.E., Horton, E.B., Folland, C.K., Alexander, L.V., Rowell, D.P., Kent, E.C., Kaplan, A., 2003. Global analyses of sea surface temperature, sea ice, and night marine air temperature since the late nineteenth century. Journal of Geophysical Research 108(D14), 4407, doi:10.1029/2002JD002670.

Reche, I., Ortega-Retuerta, E., Romera, O., Pulido-Villena, E., Morales-Baquero, R., Casamayor, E.O., 2009. Effect of Saharan dust inputs on bacterial activity and community composition in Mediterranean lakes and reservoirs. Limnology and Oceanography 54(3), 869-879, doi:10.4319/lo.2009.54.3.0869.

Redfield, A.C., Ketchum, B.H., Richards, F.A., 1963. The influence of organisms on the composition of seawater. In: Hill, M.N. (Ed.), The sea, vol. 2. John Wiley \& Sons, Interscience: New York and London. pp. 2677.

Reid, P.C., Beaugrand, G., 2012. Global synchrony of an accelerating rise in sea surface temperature. Journal of the Marine Biological Association of the United Kingdom 92(7), 1435-1450, doi: $10.1017 /$ S0025315412000549.

Reigstad, M., Wassmann, P., 2007. Does Phaeocystis spp. contribute significantly to vertical export of organic carbon? Biogeochemistry 83(1-3), 217-234, doi:10.1007/s10533-007-9093-3.

Reusch, T.B.H., Boyd, P.W., 2013. Experimental evolution meets marine phytoplankton. Evolution 67(7), 18491859, doi:10.1111/evo.12035.

Richards, F.A., 1965. Anoxic basins and fjords. In: Riley, J.P., Skirrow, D. (Eds.), Chemical Oceanography, vol. 1. Academic Press, London, pp. 611-645.

Riebesell, U., 1992. The formation of large marine snow and its sustained residence in surface waters. Limnology and Oceanography 37(1), 63-76.

Riebesell, U., Reigstad, M., Wassmann, P., Noji, T., Passow, U., 1995. On the trophic fate of Phaeocystis pouchetii (hariot): VI. Significance of Phaeocystis-derived mucus for vertical flux. Netherlands Journal of Sea Research 33(2), 193-203, doi:10.1016/0077-7579(95)90006-3.

Riebesell, U., Schulz, K.G., Bellerby, R.G.J., Botros, M., Fritsche, P., Meyerhofer, M., Neill, C., Nondal, G., Oschlies, A., Wohlers, J., Zollner, E., 2007. Enhanced biological carbon consumption in a high $\mathrm{CO}_{2}$ ocean. Nature 450(7169), 545-548, doi:10.1038/nature06267.

Rinaldi, A., Vollenweider, R.A., Montanari, G., Ferrari, C.R., Ghetti, A., 1995. Mucilages in Italian seas: the Adriatic and Tyrrhenian Seas, 1988-1991. Science of the Total Environment 165(1-3), 165-183, doi:10.1016/0048-9697(95)04550-K.

Rochelle-Newall, E., Mari, X., Pringault, O., 2010. Sticking properties of transparent exopolymeric particles (TEP) during aging and biodegradation. Journal of Plankton Research 32(10), 1433-1442, doi:10.1093/plankt/fbq060.

Rost, B., Zondervan, I., Wolf-Gladrow, D., 2008. Sensitivity of phytoplankton to future changes in ocean carbonate chemistry: current knowledge, contradictions and research directions. Marine Ecology Progress Series 373, 227-237, doi:10.3354/meps07776.

Russell, L.M., Hawkins, L.N., Frossard, A.A., Quinn, P.K., Bates, T.S., 2010. Carbohydrate-like composition of submicron atmospheric particles and their production from ocean bubble bursting. Proceedings of the National Academy of Sciences of the United States of America 107(15), 6652-6657, doi:10.1073/pnas.0908905107.

Ryan, J.P., Fischer, A.M., Kudela, R.M., McManus, M.A., Myers, J.S., Paduan, J.D., Ruhsam, C.M., Woodson, C.B., Zhang, Y., 2010. Recurrent frontal slicks of a coastal ocean upwelling shadow. Journal of Geophysical Research 115, C12070, doi:10.1029/2010JC006398. 
Salter, I., Kemp, A.E.S., Lampitt, R.S., Gledhill, M., 2010. The association between biogenic and inorganic minerals and the amino acid composition of settling particles. Limnology and Oceanography 55(5), 22072218, doi:10.4319/lo.2010.55.5.2207.

Sambrotto, R.N., Savidge, G., Robinson, C., Boyd, P.W., Takahashi, T., Karl, D.M., Langdon, C., Chipman, D., Marra, J., Codispoti, L., 1993. Elevated consumption of carbon relative to nitrogen in the surface ocean. Nature 363(6426), 248-250, doi:10.1038/363248a0.

Sanders, R., Morris, P.J., Poulton, A.J., Stinchcombe, M.C., Charalampopoulou, A., Lucas, M.I., Thomalla, S.J., 2010. Does a ballast effect occur in the surface ocean? Geophysical Research Letters 37, L08602, doi:10.1029/2010GL042574.

Schiebel, R. 2002. Planktic foraminiferal sedimentation and the marine calcite budget. Global Biogeochemical Cycles 16(4), 1065, doi:10.1029/2001GB001459.

Schuster, S., Herndl, G.J., 1995. Formation and significance of transparent exopolymeric particles in the northern Adriatic Sea. Marine Ecology Progress Series 124(1-3), 227-236, doi:10.3354/meps 124227.

Seebah, S., Fairfield, C., Ullrich, M.S., Passow, U., 2014. Aggregation and sedimentation of Thalassiosira weissflogii (diatom) in a warmer and more acidified future ocean. PLoS One 9(11), e112379, doi:10.1371/journal.pone.0112379.

Sieburth, J. McN., Willis, P.-J., Johnson, K.M., Burney, C.M., Lavoie, D.M., Hinga, K.R., Caron, D.A., French III, F.W., Johnson, P.W., Davis, P.G., 1976. Dissolved organic matter and heterotrophic microneuston in the surface microlayers of the North Atlantic. Science 194(4272),1415-1418.

Seuront, L., 2010. Fractals and Multifractals in Ecology and Aquatic Science (CRC Press, Boca Raton, Florida, USA).

Seuront, L., Lacheze, C., Doubell, M.J., Seymour, J.R., Van Dongen-Vogels, V., Newton, K., Alderkamp, A.C. Mitchell, J.G., 2007. The influence of Phaeocystis globosa on microscale spatial patterns of chlorophyll $a$ and bulk-phase seawater viscosity. Biogeochemistry 83(1-3), 173-188, doi:10.1007/s10533-007-9097-z.

Seuront, L., Leterme, S.C., Seymour, J.R., Mitchell, J.G., Ashcroft, D., Noble, W., Thomson, P.G., Davidson, A.T., van den Enden, R., Scott, F.J., Wright, S.W., Schapira, M., Chapperon, C., Cribb, N., 2010. Role of microbial and phytoplanktonic communities in the control of seawater viscosity off East Antarctica $\left(30-80^{\circ}\right.$ E). Deep-Sea Research II 57, 877-886, doi:10.1016/j.dsr2.2008.09.018.

Seuront, L., Vincent, D., 2008. Increased seawater viscosity, Phaeocystis globosa spring bloom and Temora longicornis feeding and swimming behaviours. Marine Ecology Progress Series 363, 131-145, doi:10.3354/meps07373.

Seuront, L., Vincent, D., Mitchell, J.G., 2006. Biologically induced modification of seawater viscosity in the Eastern English Channel during a Phaeocystis globosa bloom. Journal of Marine Systems 61(3-4), 118-133, doi:10.1016/j.jmarsys.2005.04.010.

Shanks, A.L., Trent, J.D., 1980. Marine snow: sinking rates and potential role in vertical flux. Deep-Sea Research A 27(2), 137-143, doi:10.1016/0198-0149(80)90092-8.

Simon, H., Lipsewers, Y.A., Giebel, H.-A., Wiltshire, K. H., Simon, M., 2014. Temperature effects on aggregation during a spring diatom bloom, Limnology and Oceanography 59(6), 2089-2100, doi:10.4319/lo.2014.59.6.2089.

Smetacek, V., Klaas, C., Strass, V.H., Assmy, P., Montresor, M., Cisewski, B., Savoye, N., Webb, A., d'Ovidio, F., Arrieta, J.M., Bathmann, U., Bellerby, R., Berg, G.M., Croot, P., Gonzalez, S., Henjes, J., Herndl, G.J., Hoffmann, L.J., Leach, H., Losch, M., Mills, M.M., Neill, C., Peeken, I., Röttgers, R., Sachs, O., Sauter, E., Schmidt, M.M., Schwarz, J., Terbrüggen, A., Wolf-Gladrow, D., 2012. Deep carbon export from a Southern Ocean iron-fertilized diatom bloom. Nature 487(7407), 313-319, doi:10.1038/nature11229.

Smith, D.C., Steward, G.F., Long, R.A., Azam, F., 1995. Bacterial mediation of carbon fluxes during a diatom bloom in a mesocosm. Deep-Sea Research II 42(1), 75-97, doi:10.1016/0967-0645(95)00005-B.

Smith, K.L., Williams, P.M., Druffel, E.R.M., 1989. Upward fluxes of particulate organic matter in the deep North Pacific. Nature 337(6209), 724-726, doi:10.1038/337724a0.

Song, C., Ballantyne, F., Smith, V.H., 2014. Enhanced dissolved organic carbon production in aquatic ecosystems in response to elevated atmospheric $\mathrm{CO}_{2}$. Biogeochemistry 118(1-3), 49-60, doi:10.1007/s10533013-9904-7. 
Stachowitsch, M., Fanuko, N., Richter, M., 1990. Mucus aggregates in the Adriatic Sea: an overview of stages and occurrence. Marine Ecology 11(4), 327-350, doi:10.1111/j.1439-0485.1990.tb00387.x.

Steinacher, M., Joos, F., Frölicher, T.L., Bopp, L., Cadule, P., Cocco, V., Doney, S.C., Gehlen, M., Lindsay, K., Moore, J.K., Schneider, B., Segschneider, J., 2010. Projected 21st century decrease in marine productivity: a multi-model analysis. Biogeosciences 7(3), 979-1005.

Stoderegger, K.E., Herndl, G.J., 1999. Production of exopolymer particles by marine bacterioplankton under contrasting turbulence conditions. Marine Ecology Progress Series 189, 9-16, doi:10.3354/meps189009.

Sugimoto, K., Fukuda, H., Baki, M.A., Koike, I., 2007. Bacterial contributions to formation of transparent exopolymer particles (TEP) and seasonal trends in coastal waters of Sagami Bay, Japan. Aquatic Microbial Ecology 46(1), 31-41, doi:10.3354/ame046031.

Sutcliffe, W.H., Baylor, E.R., Menzel, D.W., 1963. Sea surface chemistry and Langmuir circulation. Deep-Sea Research 10(3), 233-243, doi:10.1016/0011-7471(63)90359-0.

Taucher, J., Jones, J., James, A., Brzezinski, M.A., Carlson, C.A., Riebesell, U., Passow, U., 2015. Combined effects of $\mathrm{CO}_{2}$ and temperature on carbon uptake and partitioning by the marine diatoms Thalassiosira weissflogii and Dactyliosolen fragilissimus. Limnology and Oceanography 60(3), 901-919, doi:10.1002/lno.10063.

Taucher, J., Schulz, K.G., Dittmar, T., Sommer, U., Oschlies, A., Riebesell, U., 2012. Enhanced carbon overconsumption in response to increasing temperatures during a mesocosm experiment. Biogeosciences 9(9), 3531-3545, doi:10.5194/bg-9-3531-2012.

Tedetti, M., Sempéré, R., 2006. Penetration of ultraviolet radiation in the marine environment. A review. Photochemistry and Photobiology 82(2), 389-397, doi:10.1562/2005-11-09-IR-733.

Teira, E., Pazo, M.J., Serret, P., Fernandez, E., 2001. Dissolved organic carbon production by microbial populations in the Atlantic Ocean. Limnology and Oceanography 46(6), 1370-1377.

Ternon, E., Guieu, C., Löye-Pilot, M.-D., Leblond, N., Bosc, E., Gasser, B., Miquel, J.-C., Martin, J., 2010. The impact of Saharan dust on the particulate export in the water column of the North Western Mediterranean Sea. Biogeosciences 7(3), 809-826.

Thingstad, T.F., Billen, G., 1994. Microbial degradation of Phaeocystis material in the water. Journal of Marine Systems 5(1), 55-65, doi:10.1016/0924-7963(94)90016-7.

Thingstad, T.F., Hagström, Å., Rassoulzadegan, F., 1997. Accumulation of degradable DOC in surface waters: Is it caused by a malfunctioning microbial loop? Limnology and Oceanography 42(2), 398-404.

Thomas, J.P., 1971. Release of dissolved organic matter from natural populations of marine phytoplankton. Marine Biology 11(4), 311-323, doi:10.1007/BF00352449.

Thornton, D.C.O., 2009. Effect of low pH on carbohydrate production by a marine planktonic diatom (Chaetoceros muelleri). Research Letters in Ecology, doi:10.1155/2009/105901.

Thorpe, S.A., 1992. Bubble clouds and the dynamics of the upper ocean. Quarterly Journal of the Royal Meteorological Society 118(503), 1-22, doi:10.1002/qj.49711850302.

Toggweiler, J.R., 1993. Carbon overconsumption. Nature 363(6426), 210-211, doi:10.1038/363210a0.

Tsai, W., Liu, K.-K., 2003. An assessment of the effect of sea surface surfactant on global atmosphere-ocean $\mathrm{CO}_{2}$ flux. Journal of Geophysical Research 108 (C4), 3127. doi:10.1029/2000JC000740.

Tsuda, A., Takeda, S., Saito, H., Nishioka, J., Nojiri, Y., Kudo, I., Kiyosawa, H., Shiomoto, A., Imai, K., Ono, T., Shimamoto, A., Tsumune, D., Yoshimura, T., Aono, T., Hinuma, A., Kinugasa, M., Suzuki, K., Sohrin, Y., Noiri, Y., Tani, H., Deguchi, Y., Tsurushima, N., Ogawa, H., Fukami, K., Kuma, K., Saino, T., 2003. A mesoscale iron enrichment in the western Subarctic Pacific induces a large centric diatom bloom. Science 300(5621), 958-961, doi:10.1126/science.1082000.

Tsunogai, S., Uematsu, M., Tanaka, N., Harada, K., Tanoue, E., Handa, N., 1980. A sediment trap experiment in Funka Bay, Japan - Upward flux of particulate matter in seawater. Marine Chemistry 9(4), 321-334, doi:10.1016/0304-4203(80)90032-8.

Verhoeven, J.W., 1996. Glossary of terms used in photochemistry (IUPAC Recommendations 1996). Pure and Applied Chemistry 68(12), 2223-2286. 
Verity, P.G., Villareal, T.A., Smayda, T.J., 1988. Ecological investigations of blooms of colonial Phaeocystis pouchetii. 1. Abundance, biochemical composition, and metabolic rates. Journal of Plankton Research 10(2), 219-248, doi:10.1093/plankt/10.2.219.

Volk, T., Hoffert, M.I., 1985. Ocean carbon pumps: analysis of relative strength and efficiencies of in oceandriven circulation atmospheric $\mathrm{CO}_{2}$ changes. In: Sundquist, E.T., Broecker, W.S. (Eds.), The Carbon Cycle and Atmospheric $\mathrm{CO}_{2}$ : Natural Variation Archean to Present. AGU Monograph 32. American Geophysical Union, Washington, DC, pp. 99-110.

Waite, A.M., Nodder, S.D., 2001. The effect of in situ iron addition on the sinking rates and export flux of Southern Ocean diatoms. Deep-Sea Research II 48(11-12), 2635-2654, doi:10.1016/S0967-0645(01)00012-1.

Walter, S., Peeken, I., Lochte, K., Webb, A., Bange, H.W., 2005. Nitrous oxide measurements during EIFEX, the European Iron Fertilization Experiment in the subpolar South Atlantic Ocean. Geophysical Research Letters 32(23), L23613, doi:10.1029/2005GL024619.

Ward, B.B., Kilpatrick, K.A., Renger, E.H., Eppley, R.W., 1989. Biological nitrogen cycling in the nitracline. Limnology and Oceanography 34(3), 493-513.

Wells, M.L., Goldberg, E.D., 1991. Occurrence of small colloids in sea water. Nature 353(6342), 342-344, doi: $10.1038 / 353342 \mathrm{a} 0$.

Wetz, M.S., Robbins, M.C., Paerl, H.W., 2009. Transparent exopolymer particles (TEP) in a river-dominated estuary: spatial-temporal distributions and an assessment of controls upon TEP formation. Estuaries and Coasts 33(3), 447-455, doi:10.1007/s12237-009-9143-2.

Wetzel, R.G., Hatcher, P.G., Bianchi, T.S., 1995. Natural photolysis by ultraviolet irradiance of recalcitrant dissolved organic matter to simple substrates for rapid bacterial metabolism. Limnology and Oceanography 40(8), 1369-1380.

Williams, P.J. leB., 1995. Evidence for the seasonal accumulation of carbon-rich dissolved organic material, its scale in comparison with changes in particulate material and the consequential effect on net $\mathrm{C} / \mathrm{N}$ assimilation ratios. Marine Chemistry 51(1), 17-29, doi:10.1016/0304-4203(95)00046-T.

Williams, P.M., Carlucci, A.F., Henrichs, S.M., Van Fleet, E.S., Horrigan, S.G., Reid, F.M.H., Robertson, K.J., 1986. Chemical and microbiological studies of sea-surface films in the Southern Gulf of California and off the West Coast of Baja California. Marine Chemistry 19(1), 17-98, doi:10.1016/0304-4203(86)90033-2.

Wilson, W.B., Collier, A., 1972. The production of surface-active material by marine phytoplankton cultures. Journal of Marine Research 30, 15-26.

Wilson, T.W., Ladino, L.A., Alpert, P.A., Breckels, M.N., Brooks, I.M., Browse, J., Burrows, S.M., Carslaw, K.S., Huffman, J.A., Judd, C., Kilthau, W.P., Mason, R.H., McFiggans, G., Miller, L.A., Najera, J.J., Polishchuk, E., Rae, S., Schiller, C.L., Si, M., Temprado, J.V., Whale, T.F., Wong, J.P.S., Wurl, O., YakobiHancock, J.D., Abbatt, J.P.D., Aller, J.Y., Bertram, A.K., Knopf, D.A., Murray, B.J., 2015. A marine biogenic source of atmospheric ice-nucleating particles. Nature 525, 234-238, doi:10.1038/nature 14986.

Wohlers, J., Engel, A., Zöllner, E., Breithaupt, P., Jürgens, K., Hoppe, H.-G., Sommer, U., Riebesell, U., 2009. Changes in biogenic carbon flow in response to sea surface warming. Proceedings of the National Academy of Sciences of the United States of America 106(17), 7067-7072, doi:10.1073/pnas.0812743106.

Wolanski, E., Richmond, R.H., Davis, G., Bonito, V., 2003. Water and fine sediment dynamics in transient river plumes in a small, reef-fringed bay, Guam. Estuarine, Coastal and Shelf Science 56(5-6), 1029-1040, doi:10.1016/S0272-7714(02)00321-9.

Wolanski, E., Spagnol, S., 2003. Dynamics of the turbidity maximum in king Sound, tropical Western Australia. Estuarine, Coastal and Shelf Science 56(5-6), 877-890, doi:10.1016/S0272-7714(02)00214-7.

Wood, M.A., Van Valen, L.M., 1990. Paradox lost? On the release of energy-rich compounds by phytoplankton. Marine Microbial Food Webs 4, 103-116.

Wurl, O., Holmes, M., 2008. The gelatinous nature of the sea-surface microlayer. Marine Chemistry 110(1-2), 89-97, doi:10.1016/j.marchem.2008.02.009.

Wurl, O., Miller, L., Röttgers, R., Vagle, S., 2009. The distribution and fate of surface-active substances in the sea-surface microlayer and water column. Marine Chemistry 115(1-2), 1-9, doi:10.1016/j.marchem.2009.04.007. 
Wurl, O., Miller, L., Vagle, S., 2011. Production and fate of transparent exopolymer particles in the ocean. Journal of Geophysical Research 116, C00H13, doi:10.1029/2011JC007342.

Wurl, O., Stolle, C., Chu, V.T., Pham, T.T., Mari, X., 2016. Biofilm-like properties of the sea surface and predicted effects on air-sea $\mathrm{CO}_{2}$ exchange. Progress in Oceanography 144, 15-24, doi:10.1016/j.pocean.2016.03.002.

Zhang, Z.B., Cai, W.J., Liu, L.S., Liu, C.Y., Chen, F.Z., 2003. Viscosity of sea surface microlayer in Jiaozhou Bay and adjacent sea area. Chinese Journal of Oceanology and Limnology 21, 351-357.

Zhou, J., Mopper, K., Passow, U., 1998. The role of surface-active carbohydrates in the formation of transparent exopolymer particles by bubble adsorption of seawater. Limnology and Oceanography 43(8), 1860-1871, doi:10.4319/lo.1998.43.8.1860.

Ziveri, P., de Bernardic, B., Baumann, K.-H., Stolle, H.M., Mortyn, P.G., 2007. Sinking of coccolith carbonate and potential contribution to organic carbon ballasting in the deep ocean. Deep-Sea Research II 54, 659-675, doi:10.1016/j.dsr2.2007.01.006.

Žutic, V., Ćosović, B., Marčenko, E., Bihari, N., Krsinic, F., 1981. Surfactant production by marine phytoplankton. Marine Chemistry 10, 505-520, doi:10.1016/0304-4203(81)90004-9.

Zweifel, U.L., Norrman, B., Hagström, Å., 1993. Consumption of dissolved organic carbon by marine bacteria and demand for inorganic nutrients. Marine Ecology Progress Series 101(1-2), 23-32, doi:10.3354/meps 101023 . 


\section{SUPPLEMENTARY MATERIAL}

\section{S1) Transparent exopolymer particles and extracellular particulate carbohydrates: operational definition}

Transparent exopolymer particles are operationally defined as particulate polysaccharides that contain acidic sugar units (Alldredge et al. 1993) such as uronic acid ( $\left.\mathrm{R}-\mathrm{COO}^{-}\right)$or alkylsulfate $\left(\mathrm{R}^{-} \mathrm{OSO}_{3}{ }^{-}\right)$(Zhou et al. 1998), which stain with Alcian Blue. These acidic sugar units contribute to the overall negative charge of TEP at seawater $\mathrm{pH}$, and can readily chelate divalent cations such as $\mathrm{Ca}^{2+}$. The disappearance of TEP after the addition of glucosidase confirms that TEP consist mostly of neutral sugars sub-units (Smith et al. 1995), in particular of fucose, rahmnose, arabinose and galactose (Mopper et al. 1995, Zhou et al. 1998, Zhang et al. 2008). The monosaccharide composition of TEP is generally similar to that of the dissolved polysaccharides released by marine phytoplankton (Myklestad et al. 1972), to that of the major constituents of HMW-DOM (Aluwihare et al. 1997, Aluwihare and Repeta 1999) and to that of extracellular particulate carbohydrates produced during phytoplankton blooms (Harvey et al. 1995, Hamanaka et al. 2002). These extracellular particulate carbohydrates are operationally defined by Hamanaka et al. (2002), in contrast to cell internal carbohydrates, as particulate carbohydrates soluble after addition of methanol to seawater. Hence, although it is not certain that all extracellular particulate carbohydrates produced during phytoplankton blooms are TEP, the latter certainly represent a major fraction of phytoplankton extracellular products. Ionic bridges and hydrogen bonds between sugars of adjacent polysaccharide chains play a key role in the assemblage of TEP (Kloareg and Quatrano 1988, Mopper et al. 1995, Chin et al. 1998, Verdugo and Santschi 2010, Verdugo 2012), and render the latter sticky and highly surface-active.

\section{S2) Density of TEP-diatom aggregates: calculations}

The density of aggregates composed of combined TEP and phytoplankton cells was estimated from the concentrations of TEP and chlorophyll $a$ reported in Mari and Burd (1998) and Mari et al. (2001), assuming that: (i) the phytoplankton community was mostly composed of diatoms, (ii) all TEP aggregated with all diatom cells present, and (iii) the porosity of TEPdiatom aggregates was $90 \%$, the latter corresponding to the observation of Ploug and Passow (2007) that pore water occupies $87-98 \%$ of the aggregate's volume. The volume concentration of diatom cells was estimated from chlorophyll $a$ concentrations using a carbon:chlorophyll ratio of 67 (Riemann et al. 1989), and the following relationship between diatom carbon content $\left(C_{\text {diat }} ; \mathrm{pgC}\right.$ cell $\left.^{-1}\right)$ and volume $\left(V_{\text {diat }} ; \mu \mathrm{m}^{-3}\right)$ (Menden-Deuer and Lessard 2000):

$$
C_{\text {diat }}=0.288 V_{\text {diat }}^{0.811}
$$

The density of aggregates, $\rho_{a g g}$, was calculated from the relative contribution of TEP and diatoms to the total volume of aggregates, as:

$$
\rho_{a g g}=\rho_{w} p+(1-p)\left(\%_{T E P} / 100\right) \rho_{T E P}+(1-p)\left(1-\%_{T E P} / 100\right) \rho_{\text {diat }}
$$

where $\rho_{w}, \rho_{T E P}$ and $\rho_{\text {diat }}$ are the densities $\left(\mathrm{kg} \mathrm{m}^{-3}\right)$ of seawater, TEP and diatoms, respectively; $\%_{T E P}$ is the volume fraction of TEP within aggregates, and $p$ the porosity of aggregates. Using the above assumptions together with $\rho_{T E P}=840$ (Azetsu-Scott and Passow 2004) and $\rho_{\text {diat }}=1120 \mathrm{~kg} \mathrm{~m}^{-3}$ (van Ierland and Peperzak 1984), we estimated the density of TEP-diatom aggregates in the Kattegat (Fig. 2) and the Mediterranean Sea (Fig. 3). 


\section{S3) Density of TEP-mineral aggregates: methods}

Here we estimate the densities of aggregates at the DYFAMED site in winter and summer assuming: (i) mineral dust input of $22,210 \mathrm{mg} \mathrm{m}^{-2} \mathrm{~d}^{-1}$ (peak dust deposition at DYFAMED between 2003 and 2007; Ternon et al. 2010), (ii) TEP volume concentration of 0.2 and $8.3 \mathrm{ppm}$ during winter and summer, respectively, as measured at DYFAMED (Mari et al. 2001), (iii) homogeneous vertical distribution of TEP and mineral dust between 0 and $40 \mathrm{~m}$, (iv) aggregation of all TEP with all mineral particles, ( $v$ ) porosity of aggregates composed of mineral particles and TEP ranging from 0 to $99 \%$ (i.e. \% of volume of the aggregate occupied by seawater), and (vi) average densities of 840 and $2300 \mathrm{~kg} \mathrm{~m}^{-3}$ for TEP and dust, respectively. Literature values for the density of mineral dust particles range from 2100 to $2600 \mathrm{~kg} \mathrm{~m}^{-3}$, depending on composition (Chen et al. 2011). We used a value of $2300 \mathrm{~kg} \mathrm{~m}^{-3}$ as representative of mineral dust average density (Chou et al. 2011). The density of aggregates, $\rho_{a g g}$, was calculated using equation S2, except that $\rho_{\text {diat }}$ was replaced here by the density of minerals $\rho_{m}\left(\mathrm{~kg} \mathrm{~m}^{-3}\right)$.

\section{S4) Critical TEP-C content of aggregates for them to sink: calculations}

Assuming that the aggregates consisted of TEP and diatoms and formed in the euphotic zone (i.e. upper $75 \mathrm{~m}$ of the water column; Kwon et al. 2011), we estimated their density, $\rho_{\text {agg, }}$, using equation S2. We found that our theoretical aggregates sank only if their volume was occupied by $<33 \%$ of TEP. Based on the relationship between TEP radius $(\mu \mathrm{m})$ and TEP-C content (pg) (Mari 1999):

$$
T E P-C=0.25 r^{2.55}
$$

and considering that the TEP-C content is equivalent to about $10 \%$ of the phytoplankton carbon content for TEP particles and phytoplankton cells of the same size (Mari 1999), a theoretical aggregate of $1 \mathrm{~mm}$ diameter consisting of $33 \%$ of TEP by volume should contain 0.7 and $13.5 \mu \mathrm{g}$ of TEP-C and diatom-C, respectively, i.e. $5 \%$ of TEP-C.

Hence our theoretical 1-mm aggregates would sink only if less than $\sim 5 \%$ of their carbon content consist of TEP, and would be buoyant when TEP would make up more than $5 \%$ of the aggregate's carbon. The formation of aggregates that would sink immediately would thus require a production rate of TEP-C that is less than $\sim 5 \%$ that of diatom carbon. Given that this theoretical estimate only depends on the values used in equation $\mathrm{S} 2$, i.e. $\rho_{w}, \rho_{T E P}, \rho_{\text {diat }}, \%_{T E P}$, $p$ and $r$, it is remarkable that it is consistent with both the field value from Hamanaka et al. (2002; our Table 1) and the global TEP-C production rate, which is estimated to be $5-10 \%$ of the ocean's primary production (Section 1.2).

\section{S5) Do non-sinking TEP occur in the dark ocean?}

A non-sinking POC pool, similar to that occurring in surface waters, may exist in the dark ocean (i.e. from the base of the euphotic zone to the seabed). The downward export of organic material (i.e. sinking POC and downward mixed DOC) from the surface is supposed to ultimately fuel heterotrophic activity in the dark ocean, and to supply the deep ocean's food webs with bioavailable organic carbon reaching a steady-state between sources and sinks. However, several studies have reported major imbalances between the influx of organic 
substrates and carbon demand of deep-water bacterial communities (Boyd et al. 1999, Reinthaler et al. 2006, Steinberg et al. 2008, Baltar et al. 2009, Baltar et al. 2010, Burd et al. 2010), although Giering et al. (2014) were able to balance the organic carbon budget in the twilight zone of the northwestern North Atlantic Ocean.

Carbon budgets could perhaps also be closed by taking into account the possible unnoticed presence of a pool of slowly settling or suspended (even ascending) particles that escapes sampling by sediment traps. Studies on TEP in the mesopelagic zone are scarce and while some report low concentration of TEP in the dark ocean compared to the euphotic zone (Prieto et al. 2006, Ebersbach et al. 2014), other studies show no significant difference in TEP concentration between the surface and the upper mesopelagic layers (Kodama et al. 2014). A recent study in the Bermuda Rise area showed that TEP concentrations at $2000 \mathrm{~m}$ was as high as at 50-m depth ( 48 versus $\sim 45 \mu \mathrm{g}$ Xanthan Gum equivalent $\mathrm{L}^{-1}$, respectively; CisternasNovoa et al. 2015). A possible source of TEP in the dark ocean is bacterial activity (OrtegaRetuerta et al. 2009a).

Bacterial activity can also lead to the production of TEP in open-ocean deep-sea hydrothermal plume environments (Maruyama et al. 1993, Shackelford and Cowen 2006, Prieto and Cowen 2007). For example, bacteria isolated from deep-sea hydrothermal vents can secrete high-molecular-weight acidic extracellular polysaccharides (Raguénès et al. 1996), and vent-associated bacteria form microbial mats from which exopolysaccharides secretions can be released into the overlying water (Jannasch and Wirsen 1981). As a result of such bacterial activity, exopolysaccharides are released around hydrothermal vents (Raguénès et al. 1997, Toner et al. 2009).

Another potential source of TEP precursors in the dark ocean could be benthic activity. Although, to our knowledge, the production of TEP precursors from sediments has not yet been investigated, the role of sediments as a significant source of DOM to overlying waters in the deep ocean has been documented with benthic DOM fluxes ranging from $\sim 0.1$ to $3 \mathrm{mmol} \mathrm{C} \mathrm{m}^{-2} \mathrm{~d}^{-1}$ (Burdige 2002). In addition, some benthic filter feeders have been shown to produce TEP (McKee et al. 2005, Heinonen et al. 2007, Li et al. 2008).

Assuming that DOM produced in the seabed can coagulate to form particulate polysaccharides with TEP-like properties (i.e. low density and high sticking properties), these particles could ascend in the water column and lead to the reduction of aggregate settling velocity when sticking to them, hence leading to the formation of slowly sinking material. The occurrence of ascending "gelatinous masses" with a high C:N molar ratio in the deep North Pacific, as observed using inverted sediment traps (Smith et al. 1989), supports the idea that TEP-like material can be produced at depth and ascend. This mechanism could contribute to the formation of deep (McCave 1986) and intermediate nepheloid layers containing large mucous aggregates (Dickson and McCave 1986), i.e. the build-up of such nepheloid layers could result from the encounter between ascending buoyant TEP with sinking aggregates and their subsequent aggregation into neutrally buoyant aggregates. This mechanism could explain the high TEP concentration recorded at intermediate depth (i.e. $2000 \mathrm{~m}$ ) by CisternasNovoa et al. (2015), and the occurrence of very abundant and unusually large aggregates (i.e. in the sense that their size is out of range of the usual power law relationship used to describe the size spectra of aggregates formed following the coagulation theory) containing large amounts of TEP, in the North Atlantic Ocean, between 2000 and $5500 \mathrm{~m}$ (Bochdansky et al. 2016). 


\section{References (Supplementary Material)}

Alldredge, A.L., Passow, U., Logan, B.E., 1993. The abundance and significance of a class of large, transparent organic particles in the ocean. Deep-Sea Research I 40(6), 1131-1140, doi:10.1016/0967-0637(93)90129-Q.

Aluwihare, L.I., Repeta, D.J., 1999. A comparison of the chemical characteristics of oceanic DOM and extracellular DOM produced by marine algae. Marine Ecology Progress Series 186, 105-117, doi:10.3354/meps 186105 .

Aluwihare, L.I., Repeta, D.J., Chen, R.F., 1997. A major biopolymeric component of dissolved organic carbon in surface sea water. Nature 387(6629), 166-169, doi:10.1038/387166a0.

Azetsu-Scott, K., Passow, U., 2004. Ascending marine particles: Significance of transparent exopolymer particles (TEP) in the upper ocean. Limnology and Oceanography 49(3), 741-748, doi:10.4319/lo.2004.49.3.0741.

Baltar, F., Aristegui, J., Gasol, J.M., Sintes, E., Herndl, G.J., 2009. Evidence of prokaryotic metabolism on suspended particulate organic matter in the dark waters of the subtropical North Atlantic. Limnology and Oceanography 54(1), 182-193, doi:10.4319/lo.2009.54.1.0182.

Baltar, F., Aristegui, J., Sintes, E., Gasol, J.M., Reinthaler, T., Herndl, G.J., 2010. Significance of non-sinking particulate organic carbon and dark $\mathrm{CO}_{2}$ fixation to heterotrophic carbon demand in the mesopelagic northeast Atlantic. Geophysical Research Letters 37, L09602, doi:10.1029/2010GL043105.

Bochdansky, A.B., Clouse, M.A., Herndl, G.J., 2016. Dragon kings of the deep sea: marine particles deviate markedly from the common number-size spectrum. Scientific Reports 6, 22633, doi:10.1038/srep22633.

Boyd, P.W., Sherry, N.D., Berges, J.A., Bishop, J.K.B., Calvert, S.E., Charette, M.A., Giovannoni, S.J., Goldblatt, R., Harrison, P.J., Moran, S.B., Roy, S., Soon, M., Strom, S., Thibault, D., Vergin, K.L., Whitney, F.A., Wong, C.S., 1999. Transformations of biogenic particulates from the pelagic to the deep ocean realm. Deep-Sea Research II 46(11-12), 2761-2792, doi:10.1016/S0967-0645(99)00083-1.

Burd, A.B., Hansell, D.A., Steinberg, D.K., Anderson, T.R., Aristegui, J., Baltar, F., Beaupré, S.R., Buesseler, K.O., DeHairs, F., Jackson, G.A., Kadko, D.C., Koppelmann, R., Lampitt, R.S., Nagata, T., Reinthaler, T., Robinson, C., Robison, B.H., Tamburini, C., Tanaka, T., 2010. Assessing the apparent imbalance between geochemical and biochemical indicators of meso-and bathypelagic biological activity: What the @\$\#! is wrong with present calculations of carbon budgets? Deep-Sea Research II 57(16), 1557-1571, doi:10.1016/j.dsr2.2010.02.022.

Burdige, D.J., 2002. Sediment pore waters. In: Hansell, D.A., Carlson, C.A. (Eds.), Biogeochemistry of Marine Dissolved Organic Matter. Academic Press, San Diego, CA, pp. 611-661.

Chen, G., Ziemba, L.D., Chu, D.A., Thornhill, K.L., Schuster, G.L., Winstead, E.L., Diskin, G.S., Ferrare, R.A., Burton, S.P., Ismail, S., Kooi, S.A., Omar, A.H., Slusher, D.L., Kleb, M.M., Reid, J.S., Twohy, C.H., Zhang, H., Anderson, B.E., 2011. Observations of Saharan dust microphysical and optical properties from the Eastern Atlantic during NAMMA airborne field campaign. Atmospheric Chemistry and Physics 11(2), 723740, doi:10.5194/acp-11-723-2011.

Chin, W., Orellana, M.W., Verdugo, P., 1998. Spontaneous assembly of marine dissolved organic matter into polymer gels. Nature 391(6667), 568-570, doi:10.1038/35345.

Chou, C., Stetzer, O., Weingartner, E., Juranyi, Z., Kanji, Z.A., Lohmann, U., 2011. Ice nuclei properties within a Saharan dust event at the Jungfraujoch in the Swiss Alps. Atmospheric Chemistry and Physics 11(10), 4725-4738, doi:10.5194/acp-11-4725-2011.

Cisternas-Novoa, C., Lee, C., Engel, A., 2015. Transparent exopolymer particles (TEP) and Coomassie stainable particles (CSP): Differences between their origin and vertical distributions in the ocean. Marine Chemistry 175, 56-71, doi:10.1016/j.marchem.2015.03.009.

Dickson, R.R., McCave, I.N., 1986. Nepheloid layers on the continental slope west of Porcupine Bank. DeepSea Research A 33(6), 791-818, doi:10.1016/0198-0149(86)90089-0.

Ebersbach, F., Assmy, P., Martin, P., Schulz, I., Wolzenburg, S., Nöthig, E.-M., 2014. Particle flux characterisation and sedimentation patterns of protistan plankton during the iron fertilisation experiment LOHAFEX in the Southern Ocean. Deep-Sea Research I 89, 94-103, doi:10.1016/j.dsr.2014.04.007. 
Giering, S.L.C., Sanders, R., Lampitt, R.S., Anderson, T.R., Tamburini, C., Boutrif, M., Zubkov, M.V., Marsay, C.M., Henson, S.A., Saw, K., Cook, K., Mayor, D.J., 2014. Reconciliation of the carbon budget in the ocean's twilight zone. Nature 507, 480-483, doi:10.1038/nature13123.

Hamanaka, J., Tanoue, E., Hama, T., Handa, N., 2002. Production and export of particulate fatty acids, carbohydrates and combined amino acids in the euphotic zone. Marine Chemistry 77(1), 55-69, doi:10.1016/S0304-4203(01)00075-5.

Harvey, H.R., Tuttle, J.H., Bell, J.T., 1995. Kinetics of phytoplankton decay during simulated sedimentation: changes in biochemical composition and microbial activity under oxic and anoxic conditions. Geochimica et Cosmochimica Acta 59(16), 3367-3377, doi:10.1016/0016-7037(95)00217-N.

Heinonen, K.B., Ward, J.E., Holohan, B.A., 2007. Production of transparent exopolymer particles (TEP) by benthic suspension feeders in coastal systems. Journal of Experimental Marine Biology and Ecology 341(2), 184-195, doi:10.1016/j.jembe.2006.09.019.

Jannasch, H.W., Wirsen, C.O., 1981. Morphological survey of microbial mats near deep sea thermal vents. Applied and Environmental Microbiology 41(2), 528-538.

Kloareg, B., Quatrano, R.S., 1988. Structure of cell walls of marine algae and ecophysiological functions of the matrix polysaccharides. Oceanography and Marine Biology: An Annual Review 26, 259-315.

Kodama, T., Kurogi, H., Okazaki, M., Jinbo, T., Chow, S., Tomoda, T., Ichikawa, T., Watanabe, T., 2014. Vertical distribution of transparent exopolymer particle (TEP) concentration in the oligotrophic western tropical North Pacific. Marine Ecology Progress Series 513, 29-37, doi:10.3354/meps 10954.

Kwon, E.Y., Sarmiento, J.L., Toggweiler, J.R., DeVries, T., 2011. The control of atmospheric $p \mathrm{CO}_{2}$ by ocean ventilation change: The effect of the oceanic storage of biogenic carbon. Global Biogeochemical Cycles 25, GB3026, doi:10.1029/2011GB004059.

Li, B., Ward, J.E, Holohan, B.A., 2008. Transparent exopolymer particles (TEP) from marine suspension feeders enhance particle aggregation. Marine Ecology Progress Series 357, 67-77, doi:10.3354/mep.07290.

Mari, X., 1999. Carbon content and C:N ratio of transparent exopolymeric particles (TEP) produced by bubbling exudates of diatoms. Marine Ecology Progress Series 183, 59-71, doi:10.3354/meps 183059.

Mari, X., Beauvais, S., Lemée, R., Pedrotti, M.L., 2001. Non-Redfield C:N ratio of transparent exopolymeric particles in the northwestern Mediterranean Sea. Limnology and Oceanography 46(7), 1831-1836.

Mari, X., Burd, A.B., 1998. Seasonal size spectra of transparent exopolymeric particles (TEP) in a coastal sea and comparison with those predicted using coagulation theory. Marine Ecology Progress Series 163, 63-76, doi: $10.3354 /$ meps 163063 .

Maruyama, A., Mita, N., Higashihara, T., 1993. Particulate materials and microbial assemblages around the Izena black smoking vent in the Okinawa Trough. Journal of Oceanography 49(3), 353-367, doi:10.1007/BF02269570.

McCave, I.N., 1986. Local and global aspects of the bottom nepheloid layers in the world ocean. Netherlands Journal of Sea Research 20(2-3), 167-181, doi:10.1016/0077-7579(86)90040-2.

McKee, M.P., Ward, J.E., MacDonald, B.A., Holohan, B.A., 2005. Production of transparent exopolymer particles (TEP) by the eastern oyster Crassostrea virginica. Marine Ecology Progress Series 288, 141-149, doi: $10.3354 /$ meps 288141 .

Menden-Deuer, S., Lessard, E.J., 2000. Carbon to volume relationships for dinoflagellates, diatoms, and other protist plankton. Limnology and Oceanography 45(3), 569-579.

Mopper, K., Zhou, J., Ramana, K.S., Passow, U., Dam, H.G., Drapeau, D.T., 1995. Role of surface-active carbohydrates in the flocculation of a diatom bloom in a mesocosm. Deep-Sea Research II 42(1), 47-73, doi:10.1016/0967-0645(95)00004-A.

Myklestad, S.M., Haug, A., Larsen, B., 1972. Production of carbohydrates by the marine diatom Chaetoceros affinis var. willei (Gran) Husted. II. Preliminary investigation of the extracellular polysaccharides. Journal of Experimental Marine Biology and Ecology 9(2), 137-144, doi:10.1016/0022-0981(72)90042-1.

Ploug, H., Passow, U., 2007. Direct measurement of diffusivity within diatom aggregates containing transparent exopolymer particles. Limnology and Oceanography 52(1), 1-6. 
Prieto, L., Cowen, J.P., 2007. Transparent exopolymer particles in a deep-sea hydrothermal system: Guaymas Basin, Gulf of California. Marine Biology 150(6), 1093-1101, doi:10.1007/s00227-006-0430-1.

Prieto, L., Navarro, G., Cozar, A., Echevarria, F., Garcia, C.M., 2006. Distribution of TEP in the euphotic and upper mesopelagic zones of the southern Iberian coasts. Deep-Sea Research II 53(11-13), 1314-1328, doi:10.1016/j.dsr2.2006.03.009.

Raguénès, G., Peres, A., Ruimy, R., Pignet, P., Christen, R., Loaëc, M., Rougeaux, H., Garbier, B., Guezennec J., 1997. Alteromonas infernus sp. nov., a new polysaccharide-producing bacterium isolated from a deep-sea hydrothermal vent. Journal of Applied Microbiology 82(4), 422-430, doi:10.1046/j.1365-2672.1997.00125.x.

Raguénès, G., Pignet, P., Gauthier, G., Peres, A., Christen, R., Rougeaux, H., Barbier, G., Guezennec, J., 1996. Description of a new polymer-secreting bacterium from a deep-sea hydrothermal vent, Alteromonas macleodii subsp. fijiensis, and preliminary characterization of the polymer. Applied and Environmental Microbiology 62(1), 67-73.

Reinthaler, T., van Aken, H., Veth, C., Aristegui, J., Robinson, C., Williams, P.J. leB., Lebaron, P., Herndl, G.J., 2006. Prokaryotic respiration and production in the meso- and bathypelagic realm of the eastern and western North Atlantic basin. Limnology and Oceanography 51(3), 1262-1273.

Riemann, B., Simonsen, P., Stensgaard, L., 1989. The carbon and chlorophyll content of phytoplankton from various nutrient regimes. Journal of Plankton Research 11(5), 1037-1045, doi:10.1093/plankt/11.5.1037.

Shackelford, R., Cowen, J.P., 2006. Transparent exopolymer particles (TEP) as a component of hydrothermal plume particle dynamics. Deep-Sea Research I 53(10), 1677-1694, doi:10.1016/j.dsr.2006.08.001.

Smith, D.C., Steward, G.F., Long, R.A., Azam, F., 1995. Bacterial mediation of carbon fluxes during a diatom bloom in a mesocosm. Deep-Sea Research II 42(1), 75-97, doi:10.1016/0967-0645(95)00005-B.Steinberg, D.K., Van Mooy, B.A.S., Buesseler, K.O., Boyd, P.W., Kobari, T., Karl, D.M., 2008. Bacterial vs. zooplankton control of sinking particle flux in the ocean's twilight zone. Limnology and Oceanography 53(4), 1327-1338, doi:10.4319/lo.2008.53.4.1327

Ternon, E., Guieu, C., Löye-Pilot, M.-D., Leblond, N., Bosc, E., Gasser, B., Miquel, J.-C., Martin, J., 2010. The impact of Saharan dust on the particulate export in the water column of the North Western Mediterranean Sea. Biogeosciences 7(3), 809-826

Toner, B.M., Fakra, S.C., Manganini, S.J., Santelli, C.M., Marcus, M.A., Moffett, J.W., Rouxel, O., German, C.R., Edwards, K.J., 2009. Preservation of Iron(II) by carbon-rich matrices in hydrothermal plumes. Nature Geoscience 2(3), 197-201, doi:10.1038/NGEO433.

van Ierland, E.T., Peperzak, L., 1984. Separation of marine seston and density determination of marine diatoms by density gradient centrifugation. Journal of Plankton Research 6(1), 29-44, doi:10.1093/plankt/6.1.29.

Verdugo, P., Santschi, P.H., 2010. Polymer dynamics of DOC networks and gel formation in seawater. Deep-Sea Research II 57(16), 1486-1493, doi:10.1016/j.dsr2.2010.03.002.

Verdugo, P., 2012. Marine microgels. Annual Review of Marine Science 4:375-400, doi:10.1146/annurevmarine-120709-142759.

Zhang, S., Xu, C., Santschi, P.H., 2008. Chemical composition and Th-234 (IV) binding of extracellular polymeric substances (EPS) produced by the marine diatom Amphora sp. Marine Chemistry 112(1-2), 81-92, doi:10.1016/j.marchem.2008.05.009.

Zhou, J., Mopper, K., Passow, U., 1998. The role of surface-active carbohydrates in the formation of transparent exopolymer particles by bubble adsorption of seawater. Limnology and Oceanography 43(8), 1860-1871, doi:10.4319/lo.1998.43.8.1860. 
Fig. 1. Conceptual representation of the creation of a large pool of DOM that is not stoichiometrically locked into the Redfield C:N ratio, from which TEP are formed by coagulation.

Fig. 2. Seasonal variations in the Kattegat: TEP and chlorophyll a concentrations (based on 1995 data; Mari and Burd 1998), estimated average density of TEP-diatom aggregates, and POC flux in sediment traps (average POC flux from 1989 to 1997 sediment traps data; Carstensen et al. 2003).

Fig. 3. Seasonal variations in the northwestern Mediterranean Sea (DYFAMED site) in 1999: TEP and chlorophyll a concentrations (based on data from Mari et al. 2001), estimated average density of TEP-diatom aggregates, and POC flux in sediment traps at $200 \mathrm{~m}$ (Miquel et al. 2011).

Fig.4. Model depicting variations in the density of mixed aggregates of TEP and minerals at the DYFAMED site as a function of the volume fractions of TEP and mineral particles in aggregates, assuming that the porosity of aggregates ranged from 0 to $99 \%$. Aggregates with a density higher than that of seawater (horizontal red line) are negatively buoyant and thus sink, whereas those with a density lower than that of seawater are positively buoyant and thus rise. Calculations are explained in the Supplementary Material, Sections S2 for the TEP-diatom aggregates and S3 for the TEP-mineral aggregates.

Fig. 5. Examples of TEP formed by surface coagulation. Pictures taken at $\times 250$ magnification from naturally occurring TEP after Alcian Blue staining ( $X$. Mari).

Fig. 6. Relationship between local e-flushing time (LeFT) and the intraspecific TEP stickiness (noted $\alpha$ ) in the lagoon of New Caledonia (modified from Mari et al. 2007a and Mari and Robert 2008).

Fig. 7. Conceptual model summarizing the effect of TEP stickiness on the density of aggregates and the downward export of POC from surface waters for a constant amount of dense particles. Depending on TEP stickiness at the time of aggregation, the fraction of dense particles in the resulting aggregates varies.

Fig. 8. Conceptual model summarizing the effect of aging of aggregates (both in surface waters and during sinking) on their density. The delay between aggregate formation and sinking (i.e. retention time) depends on the initial ratio between TEP and dense particles, and the rates of bacterial degradation and photodegradation in surface waters.

Fig. 9. Schematic representation of the export delay (i.e. the time lag between primary production and downward POC export, and the resulting spatial decoupling between the two carbon fluxes) caused by the non-sinking TEP pool, and its effect on lowering the density of organic aggregates.

Fig. 10. [a] Fraction of TEP-C that remains in aggregates (Y-axis) as a function of the time since aggregates formed (X-axis) and of the initial fraction of TEP-C in aggregates (family of curves). Horizontal dashed line: critical 5\% TEP-C fraction, i.e. aggregates below the line sink below the euphotic zone and those above are retained in the euphotic zone. [b] Fraction of aggregates remaining at a given depth (i.e. not remineralized) in comparison to the initial aggregates formed at $25 \mathrm{~m}$ depth, as a function of the initial fraction of TEP-C in aggregates (family of curves). Horizontal line at $75 \mathrm{~m}$ depth: bottom of the euphotic zone. [c] Fraction of aggregates that can be remineralized in the euphotic zone (Y-axis) as a function of the initial TEP-C fraction (X-axis); calculations based on results illustrated in panels [a] and [b].

Fig. 11. Effect of a $10 \%$ increase in the TEP-C production rate on the composition of the standing stock of POC (i.e. relative proportion of TEP-C and non-TEP POC) and hence on the fraction of TEP-C in POC (solid line), as a function of the retention time in the euphotic zone. The excess TEP-C is defined here as the TEP-C produced when production rate increases from 0.57 to $0.63 \mathrm{~d}^{-1}$.

Fig. 12. Increase of remineralization with depth of the fraction of $P O C$ exported from the euphotic zone at $75 \mathrm{~m}$. The vertical line represents the remineralization of $63 \%$ of the POC exported from the euphotic zone, and its intersection with the curve provides the e-folding depth, i.e. $280 \mathrm{~m}$ in this example. The curve and the e-folding depth are the same irrespective of the initial TEP-C fraction in the modeled aggregates, and only depend on the values used in equation S2 (see Supplementary Material, Section 2) for $\rho_{w}, \rho_{\text {TEP }}, \rho_{\text {diat }}$, $\%_{T E P}, p$ and $r$. 


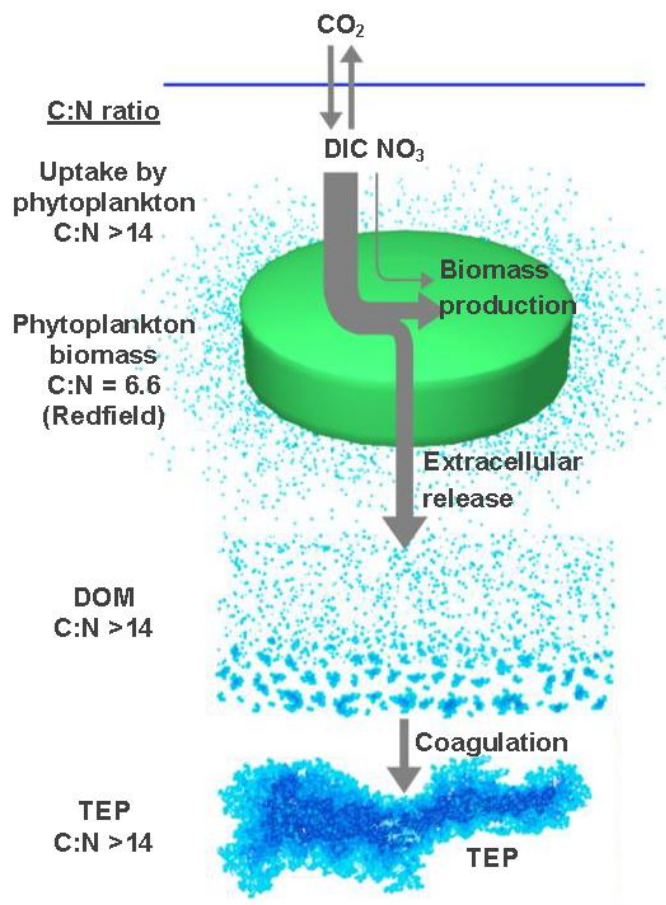

Fig. 1. 


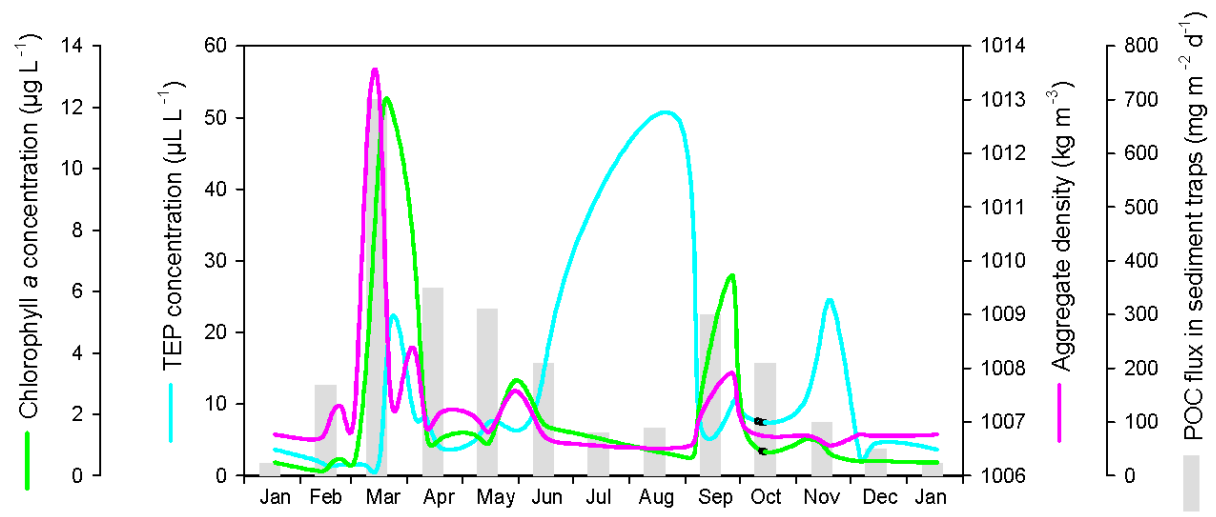

Fig. 2. 


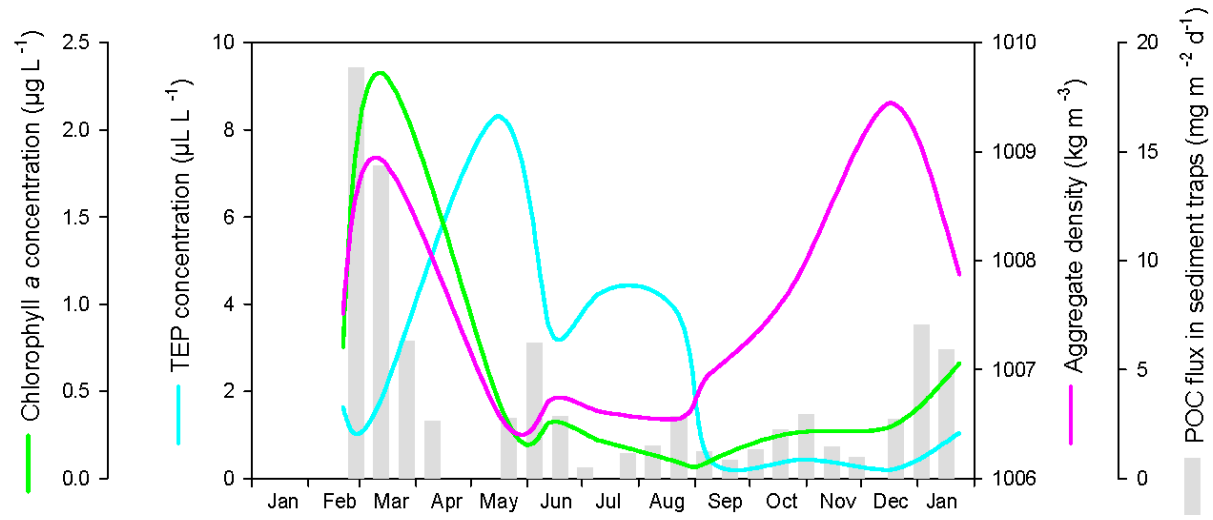

Fig. 3. 


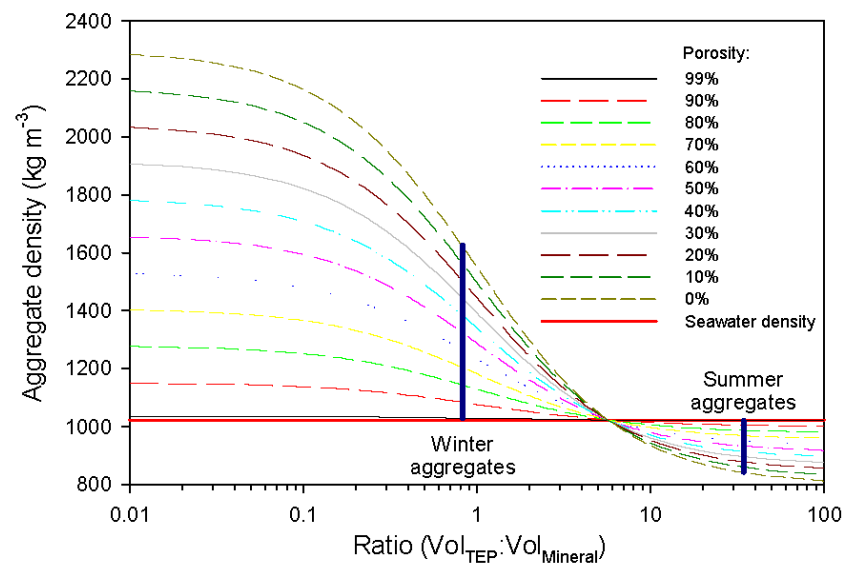

Fig.4. 


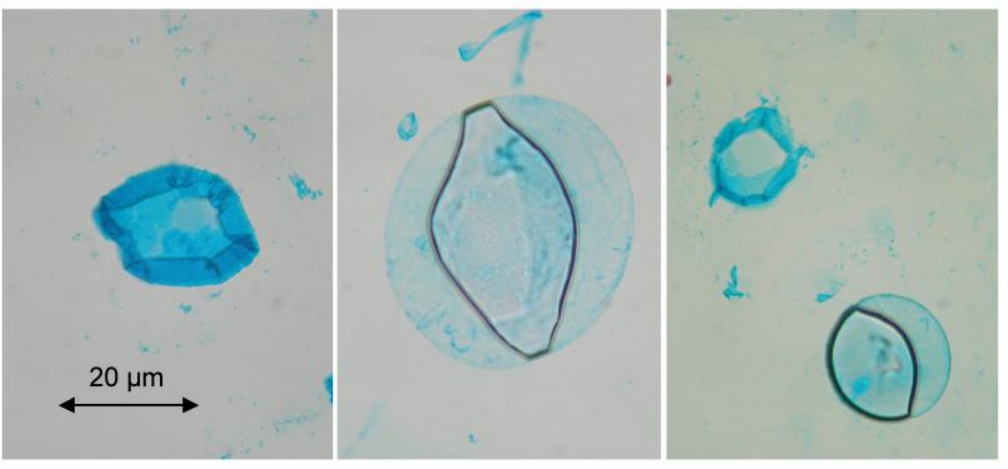

Fig. 5. 


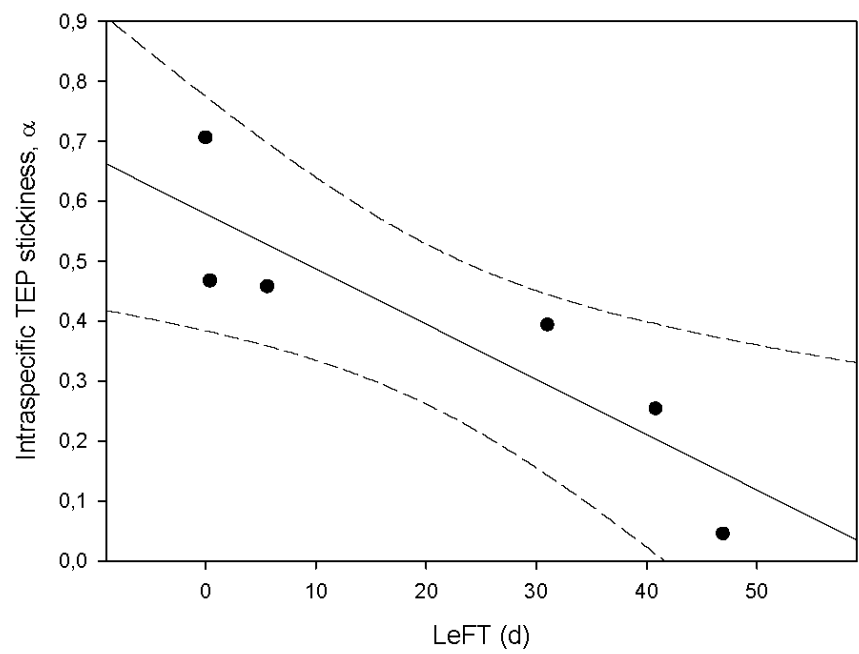

Fig. 6. 

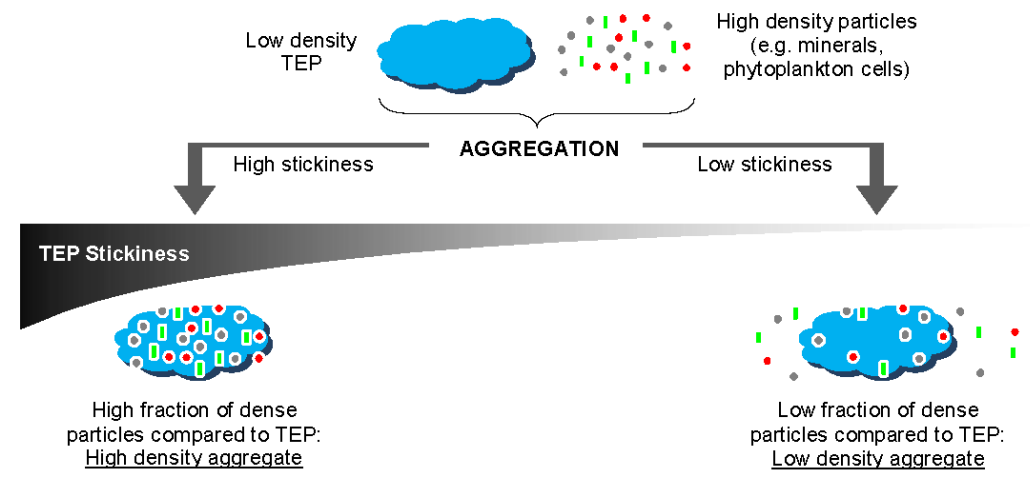

$\begin{array}{ll}\text { POC downward export } & \\ & \text { Retention time }\end{array}$

Fig. 7. 


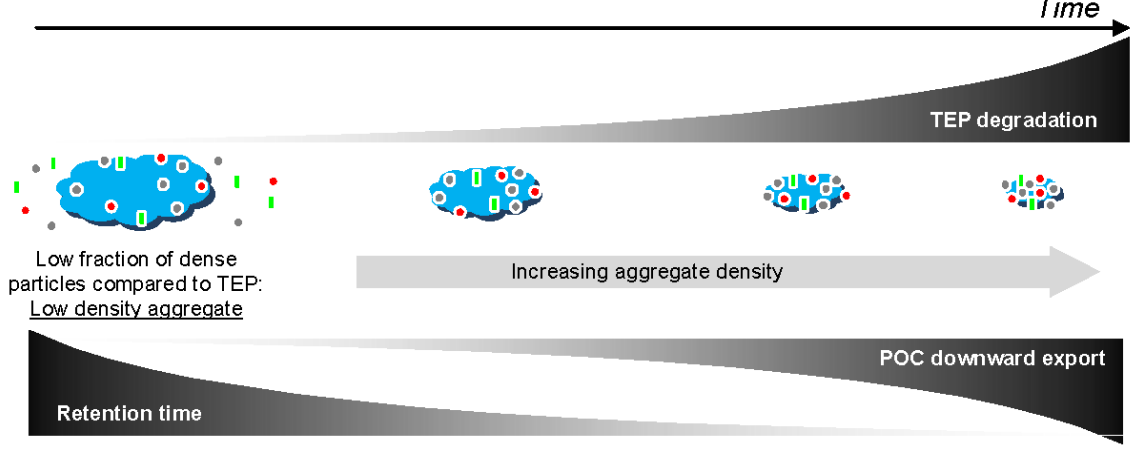

Fig. 8. 


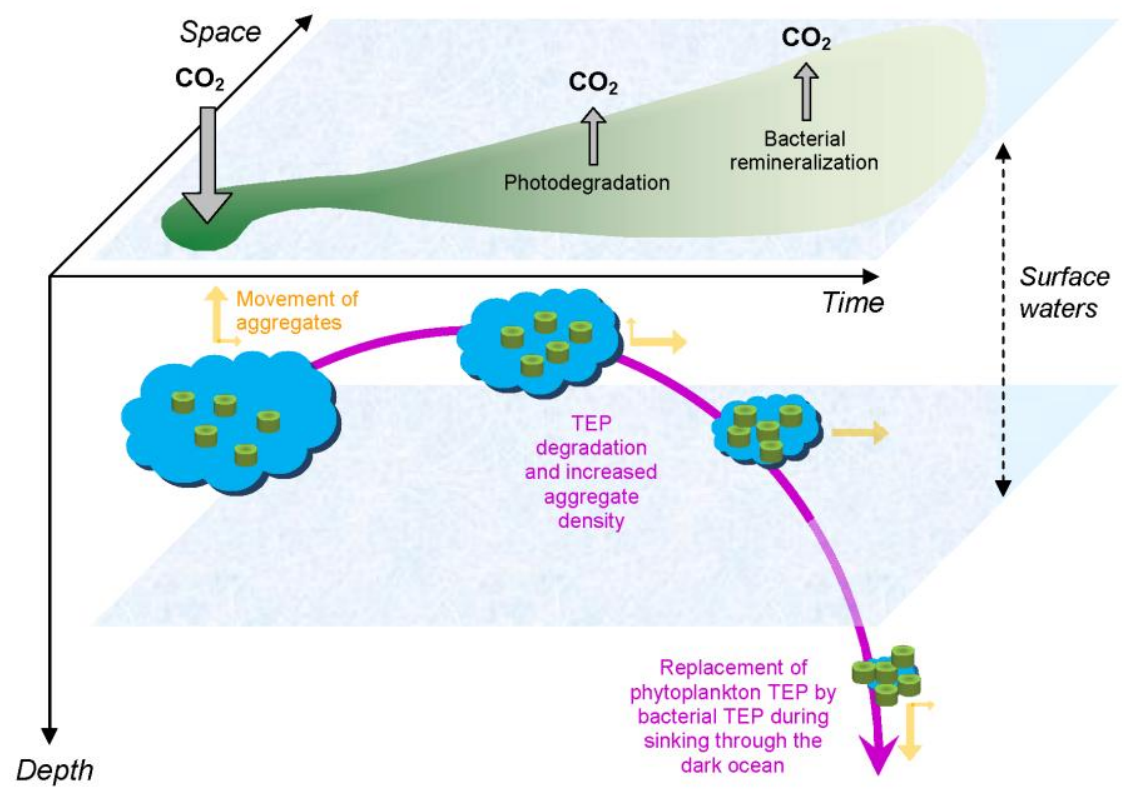

Fig. 9. 

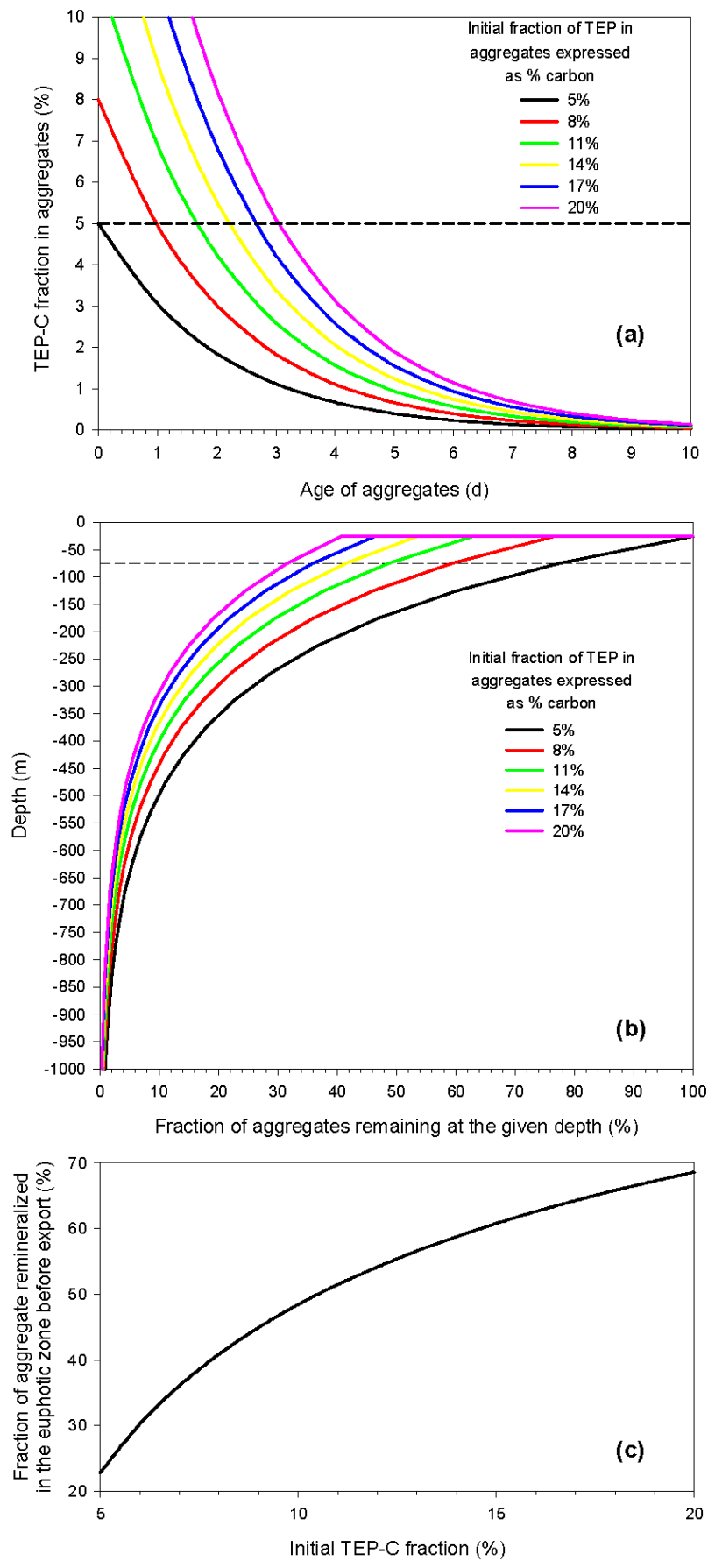

Fig. 10. 


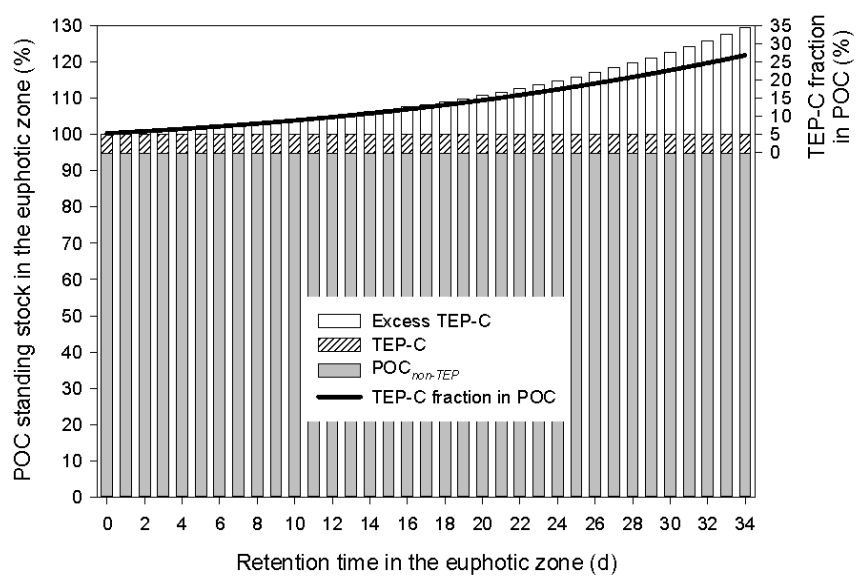

Fig. 11. 


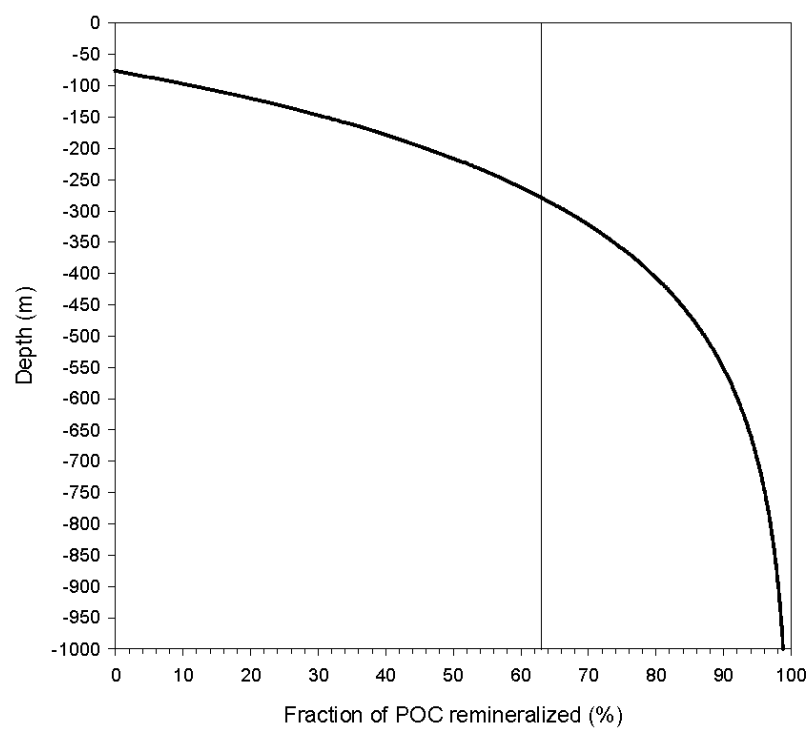

Fig. 12. 
Table 1. Rates of production, degradation and sinking of soluble particulate carbohydrates (i.e. TEP) and non-TEP POC in the euphotic zone (from Hamanaka et al. 2002).

\begin{tabular}{|c|c|c|}
\hline & TEP-C & non-TEP POC \\
\hline Production rate $\left(\mathrm{d}^{-1}\right)$ & 0.57 & 0.27 \\
\hline Retention/Degradation rate $\left(\mathrm{d}^{-1}\right)$ & 0.53 & 0.21 \\
\hline Sinking rate $\left(\mathrm{d}^{-1}\right)$ & 0.04 & 0.05 \\
\hline e ratio & 0.08 & 0.20 \\
\hline Primary Production $\left(\mathrm{mg} \mathrm{C} \mathrm{m}^{-2} \mathrm{~d}^{-1}\right)$ & 27 & 528 \\
\hline TEP-C production:Primary production $(\%)$ & & 5.1 \\
\hline
\end{tabular}


Table 2. Examples of possible effects of global warming and ocean acidification on the TEP pool in surface waters.

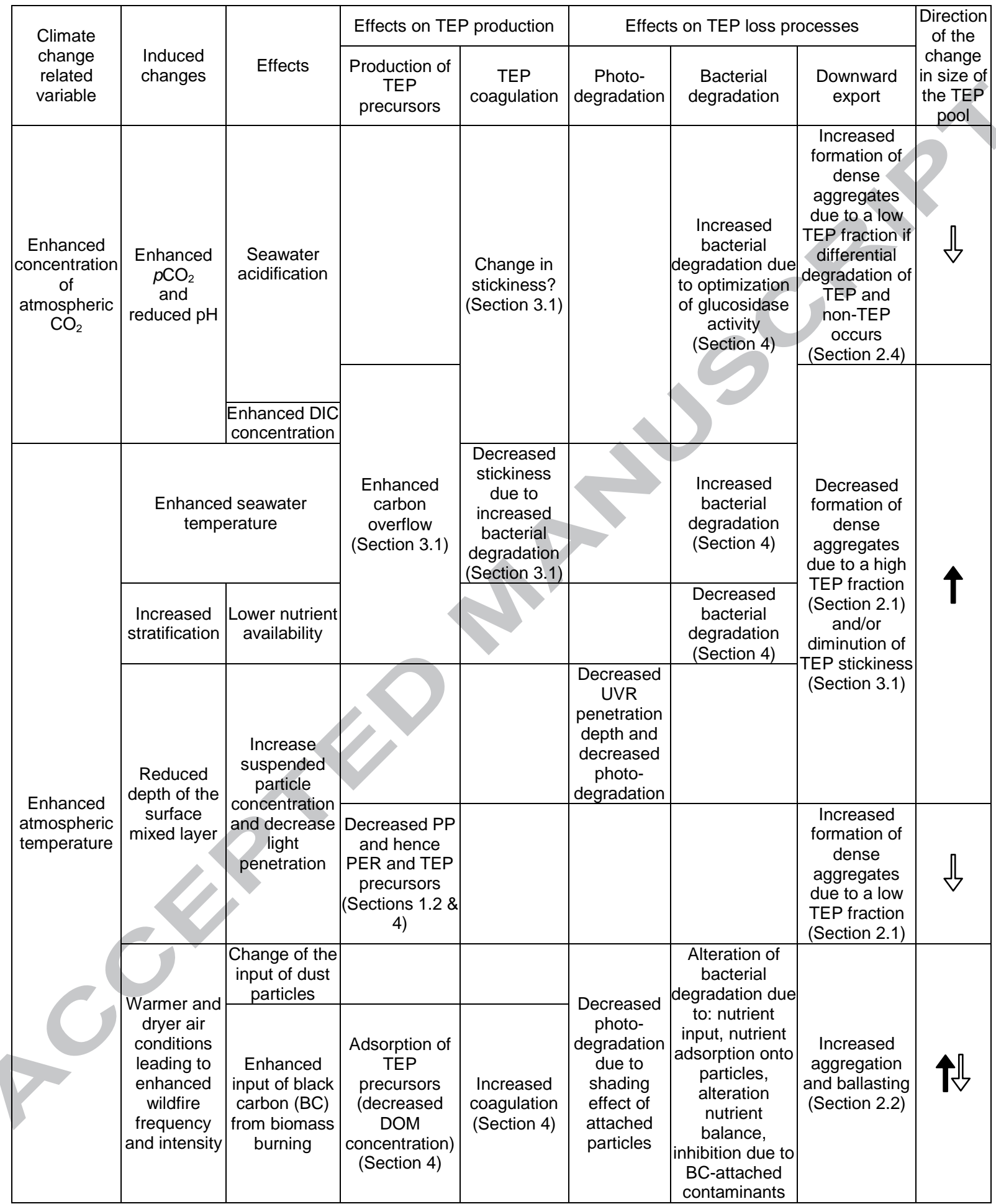




\section{Highlights:}

- Transparent exopolymer particles (TEP) accumulate in surface waters due to their low density.

- TEP sink when ballasted with high-density particles that compensate their low density.

- High relative TEP concentrations decouple primary production and downward POC export.

- The TEP fraction of POC determines POC retention and remineralization in surface waters.

- Climate change may enhance TEP production, which may decrease the biological carbon pump. 